Doktori (Ph.D.) értekezés

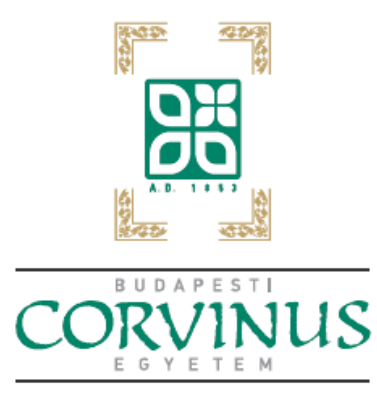

Kertészettudományi Kar

\title{
ALMA ÉS PAPRIKA EXOKARPIUMOK SZÖVETI ÉS MOLEKULÁRIS BIOLÓGIAI JELLEMZÉSE KÜLÖNBÖZŐ FEJLETTSÉGI ÁLLAPOTOKBAN ÉS A TÁROLÁS SORÁN
}

Albert Zsolt

Kertészettudományi Doktori Iskola 
A doktori iskola

megnevezése: $\quad$ Kertészettudományi Doktori Iskola

tudományága: N Növénytermesztési és kertészeti tudományok

vezetője: $\quad$ Dr. Tóth Magdolna

egyetemi tanár, DSc

Budapesti Corvinus Egyetem, Kertészettudományi Kar, Gyümölcstermő Növények Tanszék

Témavezető: $\quad$ Dr. Papp István

egyetemi tanár, $\mathrm{PhD}$

Budapesti Corvinus Egyetem, Kertészettudományi Kar,

Növényélettan és Növényi Biokémia Tanszék

A jelölt a Budapesti Corvinus Egyetem Doktori Szabályzatában elöírt valamennyi feltételnek eleget tett, az értekezés mühelyvitájában elhangzott észrevételeket és javaslatokat az értekezés átdolgozásakor figyelembe vette, ezért az értekezés védési eljárásra bocsátható. 


\section{TARTALOMJEGYZÉK}

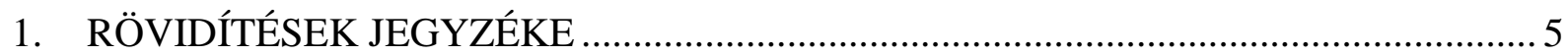

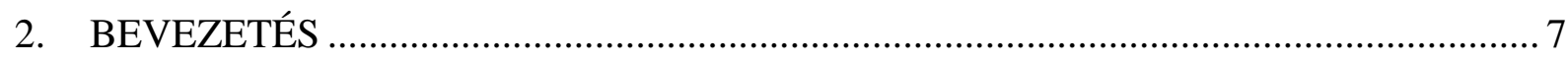

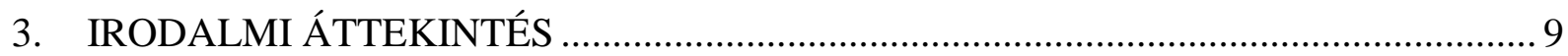

3.1. A növényi kutikula fogalma és jelentősége ........................................................... 9

3.1.1. A növényi kutikula szerepe a különböző stresszek elleni védekezésben ............ 10

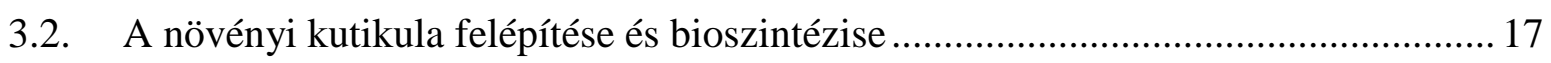

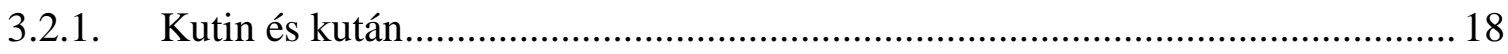

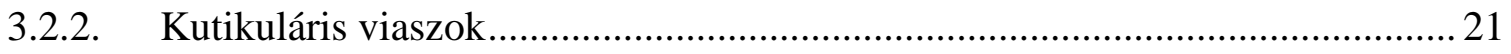

3.2.2.1. A kutikuláris viaszok jellemzése................................................................ 21

3.2.2.2. A kutikuláris viaszok bioszintézise......................................................... 24

3.2.2.3. A kutikuláris viaszok bioszintézisének szabályozása ................................ 33

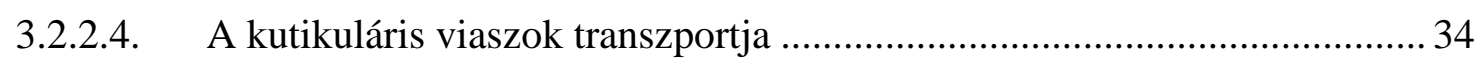

3.3. A kutikula bioszintézisében szerepet játszó gének expressziójának vizsgálata

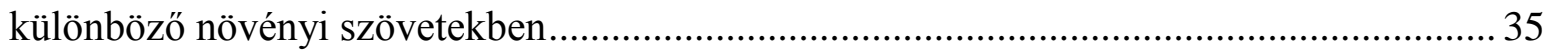

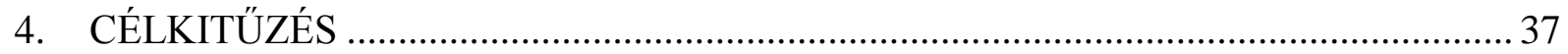

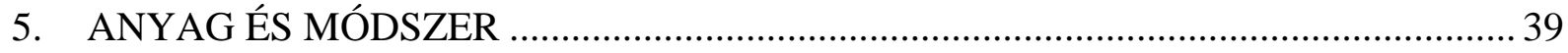

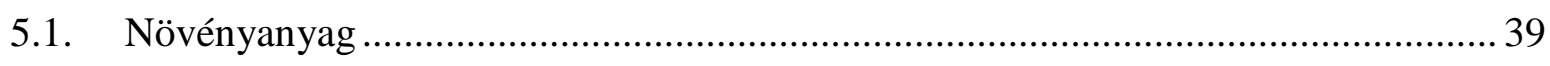

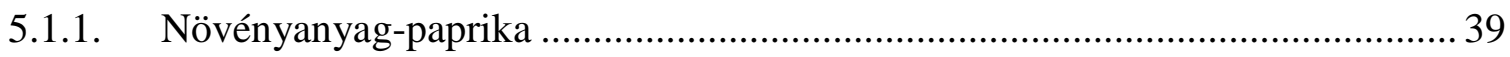

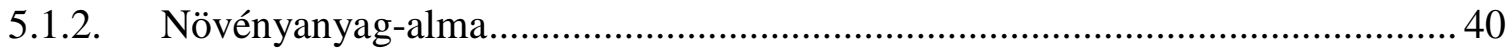

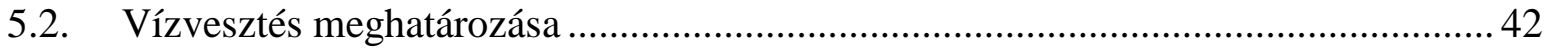

5.3. Kutikuláris viaszok leoldása és vizsgálata........................................................... 43

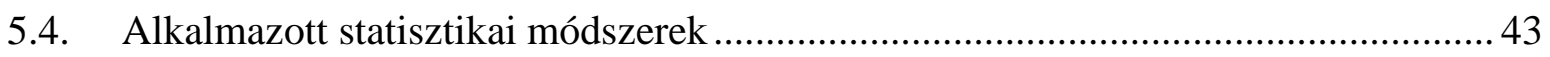

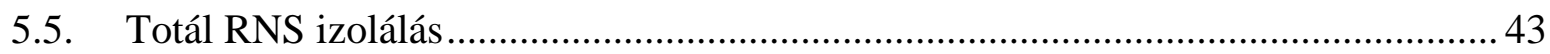

5.6. Genomi DNS szennyeződésének ellenőrzése, DN-áz kezelés ................................ 46

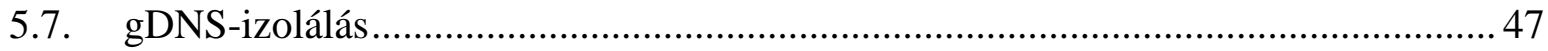

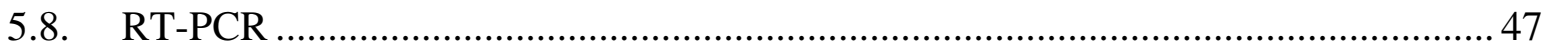

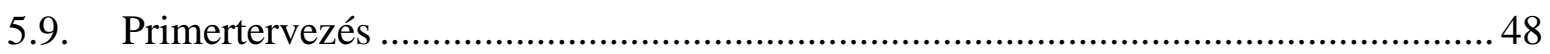

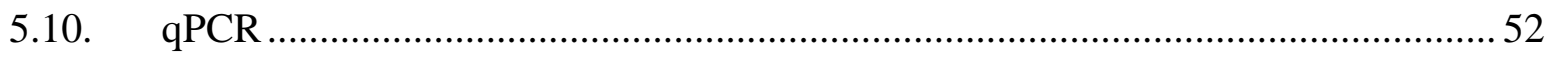

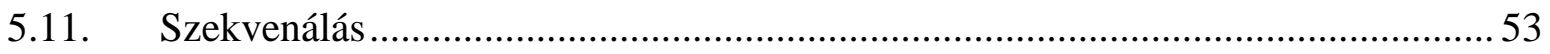

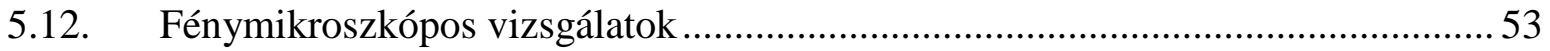

5.13. Konfokális lézer pásztázó mikroszkópos vizsgálatok......................................... 54

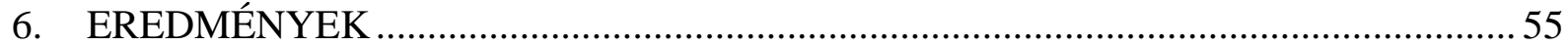


6.1. A kutikula szerepe a paprika termés vízháztartásában ........................................... 55

6.1.1. 'Hó’ és ‘Titán’ paprikák vízháztartásának jellemzése ...................................... 55

6.1.2. 'Hó’ és 'Kárpia’ paprikák vízháztartásának és kutikuláris jellemzőinek

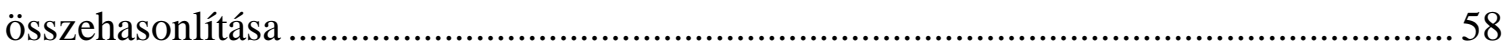

6.2. Viasz-bioszintézissel összefüggő génexpressziós vizsgálatok alma szövetekben .... 63

6.2.1. Referencia primerek alkalmazhatóságának vizsgálata alma szövetekben .63

6.2.2. Kutikuláris viaszok bioszintézisével feltételezhetően összefüggő gének

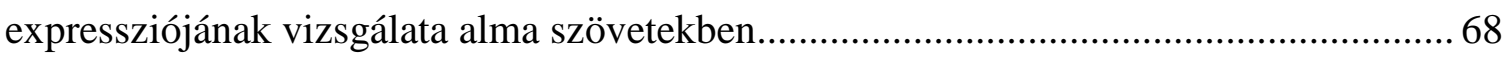

6.3. Az alma termés kutikulájának mikroszkópos vizsgálata ........................................... 76

6.4. Az alma termések vízvesztésének meghatározása................................................... 81

6.5. Az alma termések kutikuláris viaszrétegének vizsgálata ...................................... 82

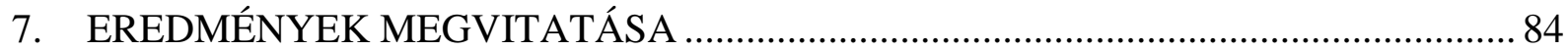

7.1. Viasz-bioszintézissel összefüggő génexpressziós vizsgálatok almaszövetekben ......84

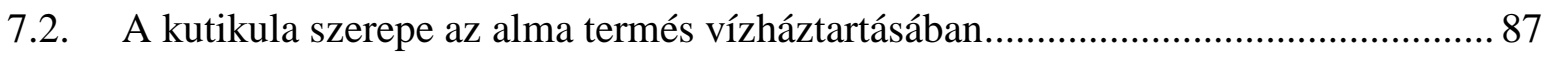

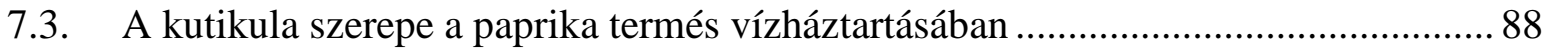

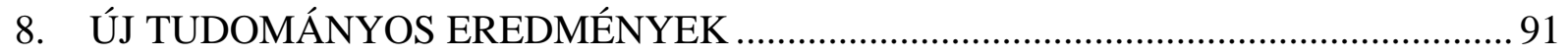

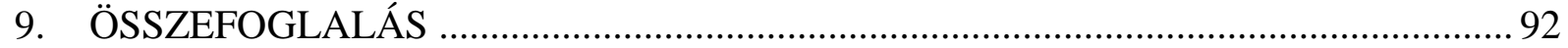

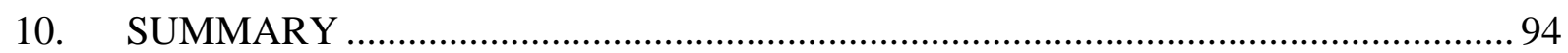

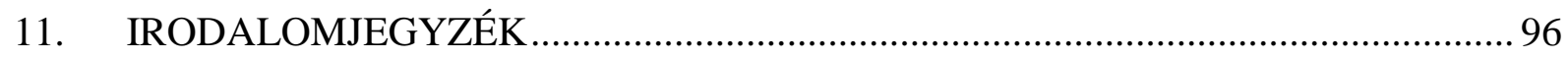

12. AZ ÉRTEKEZÉS TÉMAKÖRÉBÖL MEGJELENT PUBLIKÁCIÓK JEGYZÉKE 110

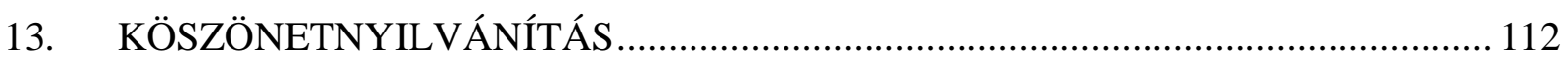

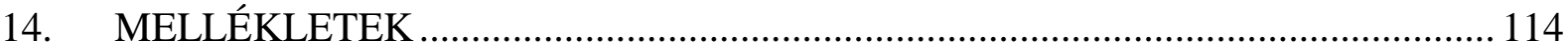

14.1. 1. Melléklet: A kutikuláris viaszok bioszintézisvel összefüggésbe hozható feltételezett alma-homológok PCR-termékeinek szekvenáltatott mintáinak nukleotid-szintü

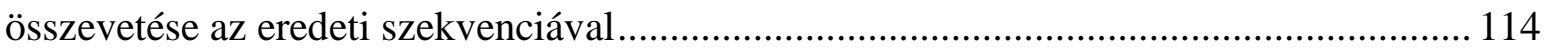

14.2. 2. Melléklet. A cDNS hígítások relatív expressziójának értékelése tubulin és ubikvitin primerekkel

14.3. 3. Melléklet: A Lacerata homológ különböző szövetekben megjelenő relatív expressziójának értékelése. 


\section{RÖVIDÍTÉSEK JEGYZÉKE}

A - adenin

ACP - acil-hordozó fehérje

ATT1 - III-típusú gének eltérő indukciója (aberrant induction of type three genes)

bp - bázispár

C - citozin

CER - eceriferum mutánsok és gének neve

CTAB - cetil-trimetilammónium bromid

DAP - beporzás utáni napok száma (days after pollination)

ECR - Transz-2,3-enoil-koenzim-A-reduktáz

elo - zsírsav elongációs mutáns Saccharomyces cerevisiae-ben

ER - endoplazmatikus retikulum

EST - expresszálódó szekvencia elem (expressed sequence tag)

fae - zsírsav elongációs mutáns Arabidopsis thaliana-ban

FAT - zsírsav-acil-ACP tioészteráz

$\mathrm{G}$ - guanin

GPAT - glicerol-3-foszfát aciltranszferáz

HCD - 3-hidroxiacil-koenzim-A-dehidratáz

KCR - 3-ketoacil-koenzim-A-reduktáz

KCS - 3-ketoacil-koenzim-A-szintáz

LACS - hosszú láncú acil-koenzim-A-szintetáz

mQ víz - milliQ víz

PCR - polimeráz láncreakció 
PUFA - többszörösen telítetlen zsírsav

qPCR -kvantitatív PCR

$\mathrm{RT}$ - reverz transzkripció

SDS - nátrium-dodecil-szulfát

$\mathrm{T}-$ timin

VLCFA - nagyon hosszú szénláncú zsírsav (C20-C34) 


\section{BEVEZETÉS}

A növényi kutikula, mely a növények felszíni részeit borító hidrofób struktúra, élettani, biokémiai és növényvédelmi szempontból is nélkülözhetetlen és jelentős határfelület. A növények szárazföldre történő kilépésétől kezdve kitüntetett szerepe van a száraz körülményekhez történő adaptációban, ezen túlmenően pedig a föld feletti részeket érő stresszek kivédésében, az azokra adott válaszokban.

A kutikula több folyamatban is betöltött szerepe tette indokolttá alaposabb kutatását, struktúrájának és bioszintézisének tisztázását. Ultrastruktúráját tekintve egy biopolimer mátrix és egy komplex lipofil elemekből álló elegy alkotja, ezek együttesen játszanak szerepet a funkcionális tulajdonságok kialakításában.

A viaszok bioszintézise a zsírsavak intracelluláris bioszintézis útvonalával kapcsolódik össze szorosan, modellezésére lúdfü növényekben került sor. A viaszok bioszintézisében részt vevő gének funkcionális genomikai vizsgálata fedte fel azt, hogy ezek a gének a genomban hol találhatók és hogyan müködnek, az egyre modernebb biotechnológiai és bioinformatikai eljárások ellenére azonban a viaszok bioszintézisének útvonalában mindmáig számos ismeretlen terület van, melyek felderítése a jövő feladata.

Kertészeti szempontból majd minden termesztett kultúra életében számottevő szerepü a kutikula, kiemelkedő gazdasági jelentőséggel a termésként fogyasztott növényi részek és ezek kutikuláris tulajdonságai bírnak. Több esetben számoltak be olyan kórokozókról, melyek fejlődését, szaporodását gátolják egyes kutikuláris komponensek, és ismereteink szerint csupán azok a patogének képesek áthágni ezt az akadályt, melyek speciális enzimes eszköztárat voltak képesek kialakítani a feladathoz. Az alma egyik legjelentősebb betegségét, az alma ventúriás varasodását épp egy ilyen kórokozó okozza, amely fertőzőképességét mai ismereteink szerint a kutikula több tulajdonsága is befolyásolhatja. A kutikuláris paraméterek által kialakított növényi tulajdonságoknak egy másik aspektusa a növényi részben raktározott víz elpárologtatása, mely olyan terméseknél, mint például a paprika, ahol zárósejtek nem jelennek meg, az egyetlen gátat a kutikula szabhatja a víz korlátok nélküli elvesztésének.

Értekezésemben a paprika termése mellett az alma termésének vizsgálatával foglalkoztam. Bár a kertészeti oktatásban az almát áltermésként említik, újabb megközelítés szerint az alma egy olyan alsó állású magházból képződő termés, melyben a magok védelmét mind a termő, mind pedig a vacok ellátják, emiatt pedig termésnek tekinthető (Podani, 2007). 
A fentiek alapján, bár a régi és új nézetek még egyaránt jelen vannak, értekezésemben az almát termésként említem, ezzel összhangban értelmezem az exo-, mezo- és endokarpium kifejezéseket is. 


\section{IRODALMI ÁTTEKINTÉS}

\subsection{A növényi kutikula fogalma és jelentősége}

A növényi kutikulát leggyakrabban a magasabb rendü növények bőrszövetének szinonímájaként említik, a latin cuticula szó is vékony bőrt jelent. Bár több más tudományág is sajátjának tekinti a fogalmat, növényi környezetben a kutikula annak modernebb értelmezése szerint egy felszíni filmréteg, mely a növény epidermális sejtfalainak kutinizálódott, külső rétegeit jelenti. A meghatározás A. P. de Candolle svájci botanikustól ered, és jórészt a fenti definícióval írható le legjobban a növényi kutikula azzal a kikötéssel, hogy nem sejtes rétegként, hanem csupán folytonos extracelluláris membránként említik. A legrégebbi növényi kutikulamaradvány körülbelül 400 millió évvel ezelőttről, a szilur-devon korszak határáról származik, a legkorábbi modern értelemben vett kutikula elszórtan található üledékekben, és a Rhyniophyta törzsbe tartozó növények sporangiumaiból származik. Bár e maradványokban nem találtak sztómák jelenlétére utaló jeleket, a devon kor kezdetével megjelentek a korai hajtásos növények és velük a sztómás struktúrákra emlékeztető jelek. A sztómás struktúra és a kutikula kialakulása szükséges velejárójaként említhető az alacsony vízellátottságú atmoszférába kikerülő, fotoszintetizáló, homoiohidratúrás élőlények szárazföldi adaptációjának.

Szerepének tárgyalásakor multifunkciós struktúraként emlegetik, a legkülsőbb növényfelszíni struktúraként ugyanis minden olyan folyamatban szerepet kap, mely a növényi felszínen vagy azon keresztül zajlik (Jenks és Ashworth, 1999). A párologtatás optimális szabályozásában például a sztómák és a kutikula együttesen töltenek be kulcsszerepet, a poláros vegyületek, valamint zárt sztómák esetén a különböző gőzök és gázok cseréjében már önmagában tölt be szabályozó szerepet. A kutikulán keresztül zajlik a lipofil vegyületek transzportja, és épp apoláris tulajdonságai révén képez védőréteget a növények felszínén. A víz ugyanis az erősen apoláris felületen cseppekben gyülik össze, és a felszínt mozgató erők hatására az azon végigguruló vízcseppek összegyüjtik az apoláris felülethez tapadt szennyezőanyagokat és öntisztító mechanizmust valósítanak meg. A jelenségnek a Lótuszeffektus nevet adták, a Nelumbo fajok felszínén, szabad szemmel is jól megfigyelhető jelenség nyomán, és mára a szuperhidrofobicitás jelensége ipari felhasználásra került (Riederer és Müller, 2006). A szárazföldre való kilépés során a növényeknek a szárazabb környezetnek való kitettség mellett az erősebb fényintenzitáshoz és sugárzáshoz is alkalmazkodniuk kellett, a komplex és különösen érzékeny fotoszintetikus pigmentrendszer 
ugyanis a közvetlen besugárzás hatására károsodik. E besugárzást csökkentik többek között a kutikula felszínén található epikutikuláris viaszkristályok, melyek annyira szétszórják és visszaverik a beérkező sugárzást, hogy az a levelek szöveteiben már tolerálható szintűvé válik a növény számára. A fényintenzitás csökkentése mellett a beérkező UV sugárzás csökkentésében is szerepet kap a kutikula, föként a külső sejtfallal és az epidermisz vakuólumaival szoros együttmúködésben. Az eddig felsoroltak mellett növényi morfogenezis során határoló ágensként funkcionál, és biotikus interakciók helyszíne a növényi felületen (Riederer és Müller, 2006).

\subsubsection{A növényi kutikula szerepe a különböző stresszek elleni védekezésben}

A növényi kutikula egyik legfontosabb szerepe a párologtatás csökkentésében, és ezáltal a szárazságstressz kivédésében kereshető. Hidrofobicitásának köszönhetően a poláros vegyületek határoló rétegeként lép fel, emellett a transzspirációs rátát azáltal is csökkenti, hogy visszaverve a beérkező sugárzást, csökkenti a sugárzás által leadott hő mennyiségét. Rizs leveleiről kloroformos bemártással eltávolítva a viaszokat azt találták, hogy a kontroll állapot kétszeresére változott a kutikula vízzel szembeni átjárhatósága. Cirok vizsgálatánál negatív korrelációt írtak le a levél kutikulájának vízzel szembeni átjárhatósága és a kutikuláris viaszok mennyisége között (Jenks és Ashwort, 1999). Különböző növényfajokkal végzett vizsgálatok azonban rámutatnak, hogy a kutikula vízzel szembeni átjárhatóságában a különböző fajok és azok különböző szervei között nagyfokú különbségek lehetnek (Schreiber, 2010.) Az is bizonyítást nyert, hogy egyes fajokban illetve genotípusokban a szárazságstressznek kitett növények felületegységre vonatkoztatott viaszmennyiségének aránya nő a nem-stresszelt növényekéihez képest. A kutatások azonban rámutatnak, hogy az apoláros rétegen keresztül történő diffúziónál komplexebb folyamatok vesznek részt a kutikula párologtatást csökkentő hatásában. Szerepet játszanak a kutikuláris viaszok komponensei: mesterséges membránok átjárhatóságának vizsgálatánál azt találták, hogy a víz transzportját hatékonyan gátolták az aldehidek, az alkán szénhidrogének és az alkoholok, míg a zsírsavak kismértékü gátlást fejtettek ki, a triterpenoidok pedig nem voltak hatással az átjárhatóságra. Érdekes módon néhány fajnál megfigyelték, hogy szárazságstressz hatására képesek a kutikuláris viaszkomponenseiket megváltoztatni, ezzel is hatékonyabbá téve a párologtatás csökkentését (Jenks és Ashworth, 1999). Számos eredmény született már a kutikuláris viaszok mennyisége és a párologtatás csökkenése közti korrelációról, azonban egyértelmű adat mindmáig nem áll rendelkezésre, ugyanis a legtöbb esetben nem számoltak a sztómák nem tökéletes záródása nyomán az azon keresztül zajló transzspirációval. Így nem 
állíthatjuk, hogy egyszerü összefüggés lehet a kutikuláris párologtatás és a kutikuláris viaszok mennyisége között, az azonban bizonyos, hogy a viaszkomponensek lánchosszának növekedése és a párologtatás csökkenése között pozitív korrelációt találtak Hedera helix levelek esetén (Shepherd és Griffiths, 2006). A kutikulán keresztül zajló párologtatás magyarázatára jelenleg két, egymással összakapcsolható elmélet van érvényben. Az egyik egy lipofil útvonalat ír le a kutin és a viaszfrakción keresztül, míg a másik egy hidrofil utat a poláris pórusokon keresztül (Riederer és Müller, 2006). A szárazságstressz vizsgálható magas sókoncentráció jelenlétében is, mely például Arachis hypogaea vagy a sóérzékeny jojoba esetén viasz-felhalmozódást okoz, de ugyanez igaz az exogén abszcizinsav jelenléte esetén is utóbbi fajnál (Shepherd és Griffiths, 2006).

A paprika termése ideális választás a kutikula vízháztartásra gyakorolt hatásának vizsgálatához, ugyanis a termés nem rendelkezik gázcserenyílásokkal, így a felületén keresztül zajló párologtatás egyetlen gátja csupán a kutikula. Posztharveszt körülmények között több módszer is elterjedt a tárolási periódus meghosszabbítására, ilyen például Fallik és munkatársainak meleg vízbe merítéssel és kefesoron keresztül történő felszíni tisztítással járó módszere, mellyel a termések tisztábbak voltak, spóramentesek, és nem indultak rohadásnak a tárolási periódus alatt. Mindezek mellett a meleg vízbe merítés a kutikula viaszrétegét kiegyenlítetté tette, így az esetleges felszíni repedések megszüntek, amelyeken keresztül a párologtatás nagyobb fokú lehetett volna (Fallik et al., 1999). Egy másik kutatás során vizsgálták a vízvesztés, az össz-lipid tartalom, a membrán integritása (elektrolitok távozása) és a lipoxigenáz enzim (LOX) aktivitásának korrelációját tíz, eltérő posztharveszt vízvesztési tulajdonságokkal rendelkező fajtánál. Szignifikáns negatív korrelációt találtak a membránlipidek összes mennyisége, valamint a vízvesztés, a membránintegritás és a LOXaktivitás között. A LOX-aktivitás és a membránlipidek közti erős negatív korreláció bizonyítékul szolgált az enzim lipidperoxidációban betöltött kulcsszerepére. Feltételezhető az is, hogy a LOX-katalizálta membránlipid-bontás a posztharveszt tárolás során a membránon keletkező sérülések révén vezethet felgyorsult vízvesztéshez is (Maalekuu et al., 2006). A posztharveszt élettartamot meghosszabbító kezelésként említik a paprika termések kitozánkezelését. A kitozán (poli- $\beta-(1,4)$-D-glükózamin) a rákok külső héjából kinyert poliszacharid, a kitinhez hasonlóan divatos kutatási területté vált úgy a nanotechnológia, mint például a humán gyógyászat és diagnosztika terén (például vérzéscsillapító alkalmazások, vagy transzdermális gyógyszerbevitel. Jayakumar et al., 2010). A paprika terméseket egyre növekvő koncentrációjú kitozánnal kezelve a tárolás alatti vízvesztés egyre inkább 
lassíthatóvá vált, 2\%-os oldatába merítve a terméseket, nagyobb aszkorbinsav-tartalmat, vízoldható szárazanyag-tartalmat és fenolos vegyületeket azonosítottak a tárolási periódus végén, mint a kontroll csoport paprikáiból (Fard et al., 2010). Egy 2006-os publikációban a vízvesztés és a hütés okozta szövetkárosodás között pozitív korrelációt tártak fel, érdekes módon azonban ugyanezt a vízvesztés és a betakarítás módja között (tépés vagy vágás) nem sikerült egyértelműen bizonyítani (Smith et al., 2006). A vízvesztés mértékével pozitív korrelációt mutató faktorként említik továbbá a paprikák kezdeti víztartalmát, a felszín/térfogat hányadosát, és a felületegységre vonatkoztatott viasztömeget. A kutikuláris viaszokkal való fedettséget és a vízvesztés mértékét negatív korrelációval jellemezték (Lownds et al., 1993). Az érettségi állapotok figyelembe vétele mellett végezték vizsgálataikat Díaz-Pérez és munkatársai (2007), és megállapították, hogy a vízvesztés mértéke az éretlen termésekben volt a legnagyobb, az általuk vizsgált kereskedelmi és biológiai érettség állapotokkal összehasonlítva. Megállapították továbbá, hogy a termések feszessége, a vízvesztésük mértéke, és a termések vízgőzre való átjárhatósága csökkent a termések tömegének növekedésével. Szintén különböző érettségi állapotban lévő paprikákkal dolgoztak Gyepes Attila és munkatársai (unpublished), akik vizsgálatuk során feltárták, hogy az éretlen állapotból az érett állapot felé haladva a kutikuláris viaszok minőségében jelentős változások zajlanak le. A hosszú láncú viaszkomponensek felhalmozódása az érési periódus legelején, a rövid láncú komponensek felhalmozódása az érési periódus végén volt megfigyelhető (Gyepes et al., unpublished). Az étkezési paprika posztharveszt minőségváltozásairól készítette doktori értekezését Zsom Tamás a Budapesti Corvinus Egyetemen. 'Hó’ és ‘Kárpia’ fajtákkal végzett vizsgálataiban meghatározta többek között azt, hogy a 'Hó' fajta három különböző érettségi állapotának változása $7{ }^{\circ} \mathrm{C}$-os hütőtárolás alatt szignifikáns eltérést mutat egymáshoz képest, a tömegvesztés lineáris lefutást követ, ennek mértékét alacsony sűrüségű polietilén csomagolással jelentősen csökkenteni lehetett. 10 és 20 ${ }^{\circ} \mathrm{C}$-os tárolás hatását is vizsgálta a termésekre, és azt találta, hogy a csomagolás nélküli 'Hó' paprikák $20{ }^{\circ} \mathrm{C}$-on tárolva közel $10 \%$-kal vesztettek többet a tömegükböl, mint $10{ }^{\circ} \mathrm{C}$-on tárolva. A ‘Kárpia’ paprikáknál ugyanez az arány állt fenn a két csoport között és érdekes módon a vízvesztés értékei a tovább pulton tartható 'Kárpia' fajta esetében mutattak magasabb értéket (Zsom, 2007). Egy 2012-es publikációban egy magas és egy alacsony vízvesztést mutató paprikagenotípus keresztezéséből származó terméseket vizsgálva közöltek érdekes adatokat a kutikula és a párologtatás összefüggéseiről. Feltárták például, hogy a kutikulában található triterpenoidok és szterolok valamint a vízvesztés mértéke között pozitív korreláció, a kutikuláris alkánok összes-triterpenoidhoz és szterolhoz viszonyított aránya 
között pedig negatív korreláció áll fenn. Az alkánok és egyéb alifás komponensek mennyisége és a vízvesztés között szintén negatív korrelációt tártak fel. A kutin összes mennyisége, a C16 monomerek és a 16-dihidroxi-hexadekánsavak mennyisége és a vízvesztés mértéke között pozitív volt a korreláció (Parsons et al., 2012).

Alma termések esetén három fő faktort említenek a vízvesztést meghatározó tényezők között: ezek a termés falának vízgőzre való átjárhatósága, a termés felszíne, valamint a gyümölcs és a külvilág közötti parciális gőznyomáskülönbség. A vízgőzre való átjárhatóság is több, további tényezőtől függ, az exokarpium felszíni struktúráitól különböző posztharveszt tényezőkig. Feltárták például, hogy ugyan a gyümölcsök felszínén az érés előrehaladtával viszonylag kevés sztóma található, a felszínen található lenticellák gázcserenyílásként szolgálnak az érett terméseken, az egyes fajták között különböző hatékonysággal biztosítva a lenticelláris transzspirációt. A kutikula vastagságát vizsgálva több kutatócsoport is megpróbált összefüggést keresni a termések falának vízzel szembeni átjárhatóságával, azonban eddig nem sikerült megbízható összefüggést találni. A kutinréteg vastagsága és a termés bőrszövetének repedése között azonban igen, és azt feltételezik, hogy a vastagabb kutikulájú fajták felszínén több repedés alakul ki, ezzel pedig nő a transzspiráció mértéke. Bizonyítást nyert az is, hogy az egyes fajták között eltérő mértékben természetesen, de az almák betakarítása előtt nagyobb a vízzel szembeni átjárhatósága a gyümölcsöknek, a minimumot a betakarítás körüli érett állapotban érik el (Maguire et al., 2001). Bizonyították továbbá egy a ‘Braeburn’ és 'Jonagold’ fajtákat érintp vizsgálatban a relatív páratartalom vízvesztésre gyakorolt hatását: mindkét fajtánál magasabb vízvesztést írtak le az alacsonyabb páratartalom jelenlétében (Tu et al., 2000). A vízvesztés mennyiségi növekedésének előidézésében lényeges faktorként említenek számos posztharveszt tényezőt is. Ilyen lehet a termések mechanikai sérülése, mely a kutatások szerint nagymértékben segíti a vízgőzre való átjárhatóságot, vagy a termések héjparásodása, mely a tünetek súlyosságától függően okoz változó mértékủ vízvesztést. Azon fajták, melyeknél a héjparásodás elég súlyos ahhoz, hogy a gyümölcsön törések és kiterjedt parás szövet jöhessen létre (pl. 'Baldwin’ vagy ‘Delicious’ fajták) a transzspiráció mértékét 50\%, vagy afölöttinek mérték, a parás területeken gyakorlatilag gátlás nélkül párologtattak a termések. Azon fajták viszont, melyek héjparásodása kifejezetten a felszíni szövetrétegeket érinti, mint például a ‘Golden Delicious’ fajtánál a vízvesztés mértéke csupán 8\% körüli volt. A fent felsoroltakon kívül a vízvesztés mértékét a vízzel szembeni átjárhatóság kialakításán keresztül befolyásolja továbbá az érettség állapota, a betakarítás ideje és a termesztés körülményei, valamint maga a fajta 
(Maguire et al., 2001). Körte esetén a vízvesztés mértékét erősen fajtafüggőnek jellemzték, azonban a tömegvesztést a tárolás időtartamával lineáris összefüggéssel tudták leírni, minden vizsgált fajta esetében ('Turandot', 'Carmen', 'Tosca', 'Coscia', 'Etrusca' és 'Precoce di Fiorano') (Pasquariello et al., 2013).

A növényi felszínre beérkező sugárzásból az UV-A és UV-B sugarak vannak káros hatással a növekedésre, közülük is az UV-B bizonyult erősebb hatásúnak, mely sugárzás az utóbbi évek során, feltehetően az atmoszféra felsőbb régióiba kerüli klór- és fluortartalmú szénhidrogének miatti ózon-mennyiség csökkenése miatt nagyobb mennyiségben jut el a földfelszínig. A kutatások feltárták, hogy a beérkező UV-B sugárzás fő gátját az epidermális sejtréteg flavonoidjai jelentik, ezek a vegyületek képesek elnyelni az említett sugarakat. Viaszosodott és kevésbé viaszos felszínű növények összehasonlításai alapján elmondható, hogy a kutikuláris felszínen jelenlévő eltérő morfológiájú viaszkristályok játszhatják a legnagyobb szerepet a beérkező sugárzás visszatükrözésében (Shepherd és Griffiths, 2006). Az egyre magasabban fekvő területek meghódítása egyre nagyobb kitettséget is jelentett az UV-stressznek, épp emiatt a magasabb területek növényei gyakran vastagabb kutikularéteggel jellemezhetők, ahogyan ez megfigyelhető volt például a Pinus abies és a Pinus cembra fajok tülevelein eltérő magasságokban (Shepherd és Griffiths, 2006). Az UV spektrum kivédése mellett egyes növényeknél a látható fény tartományában történő szürésre is szükség van: a Cotyledon orbiculata esetén például a kutikuláris viaszok eltávolítása fotoinhibíciót eredményezett, a mérések alapján a beérkező fény 60\%-át veri vissza vagy szórja szét a kutikulája. A nagyobb hullámhosszúságú fény- és az infravörös tartomány szürésével a kutikuláris viaszréteg alacsonyabb hőmérsékletet tud előidézni, ezt támasztja alá, hogy a fejlett levelek jól fejlett epikutikuláris viaszréteggel alacsonyabb hőmérsékletet, ezzel párhuzamban pedig csökkent transzspirációt mutatnak (Jenks és Ashworth, 1999).

In vitro nevelt növényeknél gyakori probléma a magas páratartalom és az alacsony fényintenzitás miatti gátolt viasz-szintézis. Ezek a növények a viaszok hiánya miatt fokozottan ki vannak téve a kiszáradásnak, és emiatt szükséges a kiültetés előtti akklimatizálásuk. A kutatások rámutatnak, hogy egyes fajoknál a viaszok termelődése növelhető volt a relatív páratartalom drasztikus csökkentésével. Mindamellett, hogy a viaszok összes mennyiségét befolyásolja, a felszíni viaszkristályok morfológiájára is hatással lehet a relatív páratartalom magas értéke, ez azonban nem tünik általános érvényünek a növényvilágban (Shepherd és Griffiths, 2006). 
Bizonyos termések esetén jelentős károkat okozhat a termések repedése, ami a növény vízháztartásával mutat szoros összefüggést. A Délkelet-Ázsiában őshonos és termesztésbe vont jávaialma (Syzygium samarangense) termései esetén például azt találták, hogy a megrepedt termések vízoldható cukor- és titrálható savtartalma, turgornyomása és poligalakturonáz aktivitása magasabb, ozmotikus potenciálja alacsonyabb volt, mint az ép terméseké. Ezeknek az eredményeknek együttes értelmezése azt mutatja, hogy az érés során bekövetkező cukor- és savfelhalmozódás csökkenti az adott szövet ozmotikus potenciálját. Az ennek hatására fellépő vízfelvétel megnövekedett nyomás potenciált eredményez, aminek eredményeként a sejtek megdagadnak, az emelkedett poligalakturonáz enzimaktivitás pedig meggyengítette a sejtfalakat, amelyek a növekvő nyomásnak engedve végül szétnyílnak (Lu és Lin, 2011). Paprikánál megállapították, hogy a termésrepedés iniciációs lépéseiben a kutikularétegen keletkeznek mikroszkopikus repedések, amelyek aztán elérik az epidermális réteget. Éppen ebben a folyamatban rejlő morfológiai különbségekre vezetik vissza az egyes fajták eltérő hajlamát a termésrepedésre. Az éjszakai párologtatás mértékének csökkenése a termésben növekvő turgornyomást idéz elő, a kutikularéteg elvékonyodásával pedig lehetővé válik végül a termés felnyílása (Aloni et al., 1998).

Érdekes összefüggés áll fenn a kutikula valamint az epidermális sejtréteg és a kalciumionok jelenléte között. A paprika és más Solanaceae zöldségfajok esetén a kalcium hiánya csúcsrothadásos betegséghez vezet, okaiként öntözési és nitrogén-trágyázási problémákat, a rosszul előkészített talajt lehet megemlíteni (Terbe et al., 2011), illetve egyes szerzők kitérnek a helyes mulcshasználatra is, melyen keresztül a talaj hőmérséklete a gyökérnövekedéshez és a vízfelvételhez optimalizálható (Mengel és Kirkby, 2001). A fentieken túl a talajok alacsony pH-értéke is befolyásoló lehet a növények kalciumionfelvételében, alacsony pH-értéknél ugyanis gátolt a $\mathrm{Ca}^{2+}$-ionok felvétele, ami kiegészülhet egyéb, savas körülmények között mobilissá váló fémionok mérgezési tüneteivel (Wiedenhoeft, 2006). A tünetek orvoslására nem alkalmazható a kalcium-lombtrágyázás, ugyanis a bőséges lombtrágyázás után levélbe kerülő kalciumionok a termésbe már nem vándorolnak el (Mengel és Kirkby, 2001). A rendszeres öntözést viszont célravezetőnek tartják, amely összefüggésben állhat a termés párologtatása során az epidermális sejtrétegben felhalmozódó kalciumionok jelenlétével. Almánál három tipikus tünete ismert a kalciumhiánynak, ezek a húsbarnulás, mely a szövetek szilárdságának csökkenésével függ össze, a keserüfoltosság, mely a gyümölcs húsát és héját egyaránt érinti, valamint a „Jonathan-foltosság”, mely csupán a héj foltosodását jelenti. A gyümölcsök a teljes 
kalciumtartalmuk 70\%-át a fejlődésük első hat hetében halmozzák fel, ezután a kalciumionok felvétele korlátozottabbá válik (Terbe et al., 2011).

A lehetséges biotikus stresszek közül a gombás betegségekre való fogékonyság létrejöttében jelentős szerephez jut a kutikula. A gombák hifái ugyanis két fó útvonalon keresztül juthatnak be a növénybe: vagy turgornyomás segítségével átnyomják a kutikulán az infekciós hifájukat, melynek nyomást nem igénylő lehetősége a nyílt sebzésen keresztül történő fertőzés, vagy pedig a felszíni lipidek enzimatikus degradációjával jutnak át a kutikulán (Jenks és Ashworth, 1999). Alma levél Venturia inaequalis fertőzésénél tárták fel, hogy a konídium által kibocsátott kutinázok termelődése azon kutin monomerek révén indukálódott, melyek a konídiummal való kapcsolat révén szabadultak fel (Köller et al., 1991). A növény felszínére kerülve a spórák az epikutikuláris viaszréteghez érnek, és azon tapadnak meg. A felszínen való megtapadás két típusát szokták elkülöníteni: a felszínre érve a spóra felszínéről vagy belsejéből eleve kész tapadást segítő anyag segítheti a megtapadást, ez a passzív mód, vagy a tapadást segítő anyagnak a felszínre kerülést követően a de novo szintézise valósul meg, ez az adhézió aktív módja (Riederer és Müller, 2006). A felszínre érkező spóra egyik további gátja lehet a csírázásban a levélfelszíni trichómák jelenléte is, melyek meggátolhatják a kutikulára érkezést, (Lazniewska et al., 2012). A kutikula kutinrétegét a penetráció fizikai gátjának, a kutikuláris viaszokat pedig kémiai gátnak tartják, ezt támasztja alá az a vizsgálat is, melyben az Erysiphe graminis eltérő appresszóriumokat fejlesztett a megváltozott összetételü kutikuláris viaszrétegen, a viaszrétegtől megfosztott növényeken pedig teljesen ép morfológiájúakat (Riederer és Müller, 2006). A kutikularéteg vastagsága és a gombás betegségre való rezisztencia között pozitív korrelációt tártak fel Capsicum annuum, Coffea arabica, Fragaria x ananassa, Rosa hybrida és számos zöldségfaj esetén, és többen beszámoltak arról is, hogy vékonyabb kutikularéteggel rendelkező mutánsok fogékonyabbak voltak egyes gombás fertőzésekre, mint a vad típusok (Jenks és Ashworth, 1999, Hammer és Evensen, 1994, Biles et al., 1993). A kutikula vastagsága és az epikutikuláris viaszkristályok morfológiája mellett a viaszok összetétele is jelentősnek bizonyult gombákkal szembeni rezisztencia kialakításában. Bebizonyították például, hogy a rozsból származó viaszok telítetlen zsírsavai, mint a linolsav és a linolénsav, antifungális hatást fejtenek ki, míg a lime (Citrus aurantifolia) telített és telítetlen zsírsavai az egyik patogén gomba növekedését gátolták. Míg a zsírsavak antifungális hatásúak, más hosszú láncú komponensek a gombák növekedésére serkentő hatással voltak, így például 1,16hexadekándial és az 1,16-hexadekándiol a Magnaporthe grisea appresszóriumának fejlődését 
segítette (Jenks és Ashworth, 1999). Avokádóból (Persea americana) származó C24, és hosszabb láncú primer alkoholok a Colletotrichum gloeosporoides spóráinak csírázását és az appresszórium kialakítását serkentették (Podila et al., 1993). A dohányt fertőző Peronospora tabacina fertőzésére fogékony a Nicotiana debneyi, és rezisztens a Nicotiana tabacum faj. Ez utóbbi viaszaiban különböző aromás vegyületeket, például a 4,8,13-duvatrién-1,3-diol $\alpha$-, és $\beta$-izomereit azonosították, melyeket a többi viasszal együttesen a felszínről eltávolítva fogékonyságot idéztek elő, a vegyület a Peronospora tabacina sporangiumainak csírázását gátolta (Reuveni et al., 1987). A felszíni viaszok azonban nem csupán elhelyezkedésük és összetételük révén játszhatnak szerepet a gazda-patogén kölcsönhatásokban, hanem apoláris tulajdonságaik miatt is. Rubus fajok vizsgálatakor azt találták, hogy a bőségesen viaszos felszínű fajták nagyobb fokú rezisztenciát mutattak a Botrytis cinerea fertőzésére, mint a kevésbé viaszos fajták, mely tulajdonság a felszín viaszok által előidézett fokozott vízlepergető képességével volt magyarázható (Jenks és Ashworth, 1999).

\subsection{A növényi kutikula felépítése és bioszintézise}

A növényi kutikula strukturálisan három föbb részből épül fel, ezek a kutin, mely egy depolimerizációra képes polimerekből álló mátrix, a kután, mely szintén polimer mátrix ám depolimerizációra képtelen, és a kutikuláris viaszok. Ez utóbbi csoport kutikulában való elhelyezkedését tekintve tovább csoportosítható intrakutikuláris- és epikutikuláris viaszokra (Pollard et al., 2008), a kutikula legfelső határfelületét az epikutikuláris viaszok adják. A kutikula általában az antiklinális sejtfalak felett a legvastagabb és gyakran ék vagy ívbolt alakban benyúlik a szomszédos epidermisz sejtek antiklinális sejtfalai közé, és e jellegzetessége miatt képez negatív képet az epidermális sejtfelszínről, és nehéz lebomlása miatt csupán ez maradt fenn a korai szárazföldi növények többsejtes struktúráinak bizonyítékaként. A kutikula legkülső részét gyakran említik valódi kutikula néven, alatta, az elsődleges és másodlagos sejtfalak zónájában változó vastagságban jelenik meg a kutin a szervfejlődés során, melyet kutikularizált rétegként is említenek. A kutikularizált réteg külvilág felőli része pektinben, a sejt felé néző része cellulózban gazdag, a pektinben dús réteget azonban cellulóz fibrillumok szövik át (Kunst és Samuels, 2003). A növényi kutikula egészében különböző mikroszkópos technikákkal vizsgálható. Elektronmikroszkópos képalkotással lehetővé válik a kutikula ultrastruktúrájának vizsgálata mellett az epikutikuláris réteg, és az ott található kutikuláris viaszkristályok megfigyelése. Beszámoltak azonban arról, hogy az elektronmikroszkópos vizsgálatok elvégzése előtti minta-előkészítés leoldja a felszíni lipofil régiókat, epikutikuláris viaszokat, ezért csupán ultrastrukturális vizsgálatokhoz a 
konfokális lézer pásztázó mikroszkópos eljárás az ajánlott (Veraverbeke et al., 2001c). A módszer előnye, hogy bár a minták festésével látványosabb eredmény kapható, de ultraibolya, illetve az ahhoz közeli tartományban a kutikula autofluoreszcenciája detektálható, izolált kutikulák vizsgálatánál ez jelentősen leegyszerüsítheti a kutikula mikroszkópos vizsgálatát (Fernández et al., 1999). A növényi kutikula azonban fénymikroszkópos képalkotással is vizsgálható, ahogy arról Buda és munkatársai is beszámoltak paradicsom termés vizsgálata kapcsán (Buda et al., 2009). A megfelelően kiválasztott festékkel láthatóvá tehetőek az apoláris régiók az epidermális szövetmintában, így a kutikula egésze, az azt átitató viaszok miatt narancsos-vöröses festődést kap a Szudán IV festést követően. A kutikuláris viaszok komponenseinek lokalizációjáról is látványos eredményt sikerült bemutatniuk Nílus kék A szulfáttal történő festés révén. Ez a festék ugyanis dikromatikus festődést mutat: vörösre festi a neutrális zsírokat és viaszokat, míg a zsírsavakat és a savas prekurzorokat kékre. Mindemellett a cellulóztartalmú sejtfalhoz is képes kötődni, itt erős kék festődés látható, amely elkülöníti a sejtfalat a kutikulától (Buda et al., 2009). Fluoreszcens képalkotásnál fontos az apoláris kutikuláris viaszok festéséhez, és a környezetük elkülönítésének vizsgálatához a sejtfalak megfestéséhez használható festékek helyes megválasztása. Az auramin O lipidek és apoláris komponensek festéséhez használható (Buda et al., 2009; Bisio et al., 1999), a poliszacharid-tartalmú sejtfal festéséhez pedig a Calcofluor White M2R használata kínál lehetőséget (Bisio et al., 1999). Előbbi a lipofil vegyületeket sárgás-zöldes, míg a Calcofluor a poliszacharid tartalmú vegyületeket fehéres-kékes színnel jelzi.

\subsubsection{Kutin és kután}

A kutinréteg szerepet kap a nemsztómás gázcserében és gazda-patogén kölcsönhatásokban, de említik a növény morfológiájának kialakításában, illetve mikrodomén szerkezetének köszönhetően a poláris komponensek transzportjában is. A kutin polimer tipikusan C16-C18 $\omega$-hidroxi zsírsavakra bontható, ellentétben a szerkezetileg hasonló szuberinnel, mely a másodlagos gyökerek és szárak peridermális rétegére, illetve gyapotszálak külsejére, vagy a gyökér endodermiszébe választódik ki. A szuberin szerkezetileg egy poliészter és egy C-C, valamint éterkötéseket tartalmazó aromás frakcióból áll, depolimerizációra kevésbé alkalmas, mint a kutin. Annak ellenére, hogy szerkezetileg is és a növényben való elhelyezkedésüket tekintve is eltérőek egymástól, a kutin és a szuberin mégis közeli rokon vegyületeknek tekinthetők, bioszintézisük ugyanis közös útvonalat követ. Mivel mind a kutin, mind a viaszok a zsírsavak bioszintézisének útvonalából vezethetők le, így a szintézisükben, modifikációjukban szerepet játszó gének között átfedés jelenik meg 
(Pollard et al., 2008). A kutin bioszintézise hidroxilációs, epoxidációs és észteresedési reakciók sorozata, melyeket az oxigén és NADP-függő enzimrendszerek katalizálnak. Mivel a szén-monoxid gátolja ezeket a reakciókat, arra következtetnek, hogy citokróm P-450-függő enzimek játszanak szerepet a bioszintézisben. Ezen enzimek kutatása még ma is folyik, többet sikerült azonosítani közülük, melyek a viasz-bioszintézisben is fontos szerepet játszanak (Nawrath, 2002). A WIN1/SHN1 transzkripciós faktor például egy vizsgálatban befolyásolta a kutin összetételét, túltermeltetése esetén összetételbeli változásokat és mennyiségi növekedést, gátlása esetén fordított hatást tapasztaltak. Ezek mellett sikerült bebizonyítani, hogy legalább egy másik kutin-bioszintézissel összefüggő gént, a LACS2-t transzkripciósan aktiválja (Kannangara et al., 2007). A kutin bioszintézisben szerepet játszó géneket három nagyobb családba sorolták, ezek CYP86A géncsaládba sorolt zsírsav-oxidázok, acil-aktivátor enzimek a LACS géncsaládban, és a GPAT géncsalád aciltranszferázai. A CYP86A és más zsírsav hidroxilázok a kutin bioszintézise mellett szignálmolekulák előállításában és a szabad zsírsavak toxikus mennyiségü felhalmozódásának megelőzésében is szerepet játszanak (Duan és Schuler, 2005). A fenti géncsaládokban eddig sikeresen azonosították a LACS2 gént, mely acil-koenzim-A-szintetáz funkciót kódol, egy citokróm P450-függő zsírsav-oxidázt, a CYP86A2-t (syn: ATT1), és két GPAT gént (GPAT4 és GPAT8) (Pollard et al., 2008). A LACS2 kutin bioszintézisében betöltött szerepét Bessire és munkatársai jellemezték 2007ben. Egy Botrytis-rezisztens Arabidopsis mutánst írtak le, melynek a sérült génje megegyezett a LACS2 szekvenciájával, és a mutáns ötszörös csökkenést mutatott a dikarboxilsavak mennyiségében, melyek a legismertebb kutin-monomerek lúdfüben. Az így kialakult kutikula nagyobb mértékü átjárhatósága segíti egyes feltételezett serkentők észlelését, és így vezethet antifungális összetevők felszíni megjelenéséhez, melyek segítették a vizsgált mutáns Botrytis és Sclerotinia fajokra való rezisztenciájának kialakulását (Bessire et al., 2007). A LACS2 enzim mutációját egy másik vizsgálatban szintén összefüggésbe hozták az optimális kutinstruktúra kialakításával és így a Botrytis-rezisztenciával, azonban a mutáns növény megváltozott tüneteket produkált a Pseudomonas syringae egy avirulens törzsével való inokulációt követően is. Ez utóbbi jelenséget arra vezették vissza, hogy a kutin jelöli ki a sztómaudvar határát lúdfü levelekben, az ultrastrukturális változásai pedig a sejtnedvek sztómaudvarba történő gyors kiáramlását teszik lehetővé, amely a kórokozó kolonizációjának primer színtere (Tang et al., 2007). Az ATT1 gént az att1 lúdfü mutánsban azonosították, mely fokozott fogékonyságot mutatott a Pseudomonas syringae egy virulens törzsére, emellett közel 30\%-kal csökkent kutintartalmat, és laza kutikuláris membránstruktúrát írtak le benne. A fentiek alapján következtetnek arra, hogy az ATT1 gén által kódolt CYP86A2 szerepet 
játszik az extracelluláris lipidek szintézisében, és mivel a mutáns nagyobb mértékủ vízzel szembeni átjárhatóságot mutatott a vad típushoz hasonlítva a vízvesztés szabályozásában kitüntetett fontosságúnak jelezték a kutikulát (Xiao et al., 2004). A GPAT gének (GPAT4 és GPAT8) vizsgálatát Arabidopsis thaliana kétszeresen inaktivált gpat4/gpat8 mutánsokon végezték, és feltárták, hogy a kutin mennyisége drasztikusan csökkent, és emellett kitettebbek voltak a kiszáradásnak és az Alternaria brassicicola fertőzésének. A gének egyenkénti túltermeltetése 80\%-os növekedést okozott a C16 és C18 kutin monomerek mennyiségében levél és szár szövetekben (Li et al., 2007). Két további mutáns, a gpat5 és a cyp86a1 vizsgálata bizonyította be, hogy e két gén is szerepet játszhat a bioszintézisben, ezekben a mutánsokban ugyanis a szuberin monomerek szintje csökkent a gyökér és a maghéj szöveteiben (Pollard et al., 2008). Emellett a GPAT5-ről bebizonyosodott, hogy expressziója a fenti két szerven túl a hipokotilban és a portokban is detektálható, továbbá a gpat5 mutáns vizsgálata során arra is fény derült, hogy a gén mutációja sem a felszíni viaszok, sem a membránalkotó vagy a tartaléklipidek mennyiségét, összetételét nem befolyásolta (Beisson et al., 2007). A felsorolt géneken kívül a cyp86a8 (syn: lacerata) mutánsban fedeztek fel kutin léziókat, azonban részletes kutin analízist mindeddig még nem közöltek erről a vonalról. A lacerata mutáns LCR génjének sérülése azonban posztgenitális szervfúziókat okozott, amiből a LCR zsírsavak $\omega$-hidroxilációjában betöltött szerepére, ezzel együtt pedig a kutin bioszintézisében való fontosságára mutattak rá (Wellesen et al., 2001). Szintén a posztgenitális szervfúziók megakadályozásának kontextusában említik a hothead mutánst $(H T H)$, mely gén expressziója minden szövettájban detektálható volt, és nem volt epidermiszspecifikus (Krolikowski et al., 2003). A fiddlehead mutáns FDH génje által kódolt fehérje szintén a vegetatív fejlődés során bekövetkező sejtfúziók gátlásában játszhat szerepet, szerkezetileg a $\beta$-ketoacil-koenzim-A-szintázok és chalkon-szintázok csoportjával mutat nagyfokú hasonlóságot (Pruitt et al., 2000). A monomerek polimerré alakulásának illetve a kész géntermékek intra- és extracelluláris transzportjának lépéseiről, illetve az ebben részt vevő kulcsenzimekről jórészt csak feltételezések állnak rendelkezésre (Pollard et al., 2008). Ismert azonban egy ABC transzporter gén, a WBC11 (syn: ABCG11), mely a kutikuláris viaszok szekréciójában játszik szerepet a CER5 (syn: ABCG12) génnel feltételezett együttműködésben, melyek így a kutin kialakításának lépéseiben vesznek részt (Bird et al., 2007 és Bird, 2008). Saladié és munkatársai jellemeztek egy DFD-nek nevezett paradicsomfajtát (delayed fruit deterioration), mely minimális puhulással, ám normális éréssel volt jellemezhető (Saladié et al., 2007). A fajtát az AC (Ailsa Craig) kontrollfajtával vetették össze. Mikroszkópos eljárásokkal nem mutatott különbséget a két fajta, a DFD kutikulának 
kutin mátrixát sűrübbnek találták, és hiányzott a kutikulájából egy flavonoid prekurzor, a naringenin kalkon, mely a kontroll fajta kutikulájának színeződését okozta, feltételezések szerint a vegyület szerepet játszhat a párologtatás szabályozásában is. A későbbiekben a DFD paradicsom kutikulájának jelentős túltermelését írták le a vad típusú paradicsom kutikulájával összevetésben, GC-MS módszereket felhasználva (Lytovchenko et al., 2009).

Bár a kutikula fö komponensei között szerepel, a kutánrétegről máig nem sokat tudunk. Annyi azonban bizonyos, hogy a kutinréteg depolimerizációját követően egy hasonló természetű, alifás anyag marad hátra, ez a kután, amely azonban makacsul ellenáll minden eljárásnak, amely megbontaná a kémiai szerkezetét. Clivia miniata levelekben azonban leírták, hogy a kután felhalmozódása csupán jóval a kutin kialakulása után kezdődik meg, ami arra engedhet következtetni, hogy a kután lerakódása csupán a sejtek fejlődésének befejeződése után kezdődik meg (Pollard et al., 2008).

\subsubsection{Kutikuláris viaszok}

\subsubsection{A kutikuláris viaszok jellemzése}

A kutikuláris viaszok vizsgálatához mindenekelőtt a viaszok kinyerése szükséges a további analízisekhez. A kutikula egészében történő vizsgálatára általában az enzimatikus emésztést szokták elvégezni (Orgell, 1954), mivel azonban a celluláz-, pektináz-tartalmú enzimkeverékek a sejtfalakon kívüli összes struktúrát szabaddá teszik, a kutikuláris viaszok csupán a kutin- és kutánrétegekkel együtt lennének vizsgálhatók. A kutikuláris viaszok további vizsgálati módszere az oldószeres leoldás és későbbi bepárlás, mely a viaszok apoláros jellegéből adódóan valamely apoláros oldószer használatát jelenti. Ezekben az oldószerekben a viaszok általában 1-10 mg/ml oldhatósággal rendelkeznek. Megoszlanak a vélemények az oldószer fajtájának kiválasztásáról, azonban a legtöbb esetben a kloroformos extrahálást alkalmazzák, néhányan említik a metilén-kloridos, n-hexános vagy a petroléteres kivonásokat is. Mindegyik eljárásban közös azonban, hogy a viaszok összetételének eltérései miatt a szerv oldószerbe mártásának ideje, hőmérséklete, az oldószer mennyisége önmagukban is gátját szabhatják a sikeres extrakciónak. A kivonás megtervezésénél lényeges elemként említhető az is, hogy levelekről történő extrakció esetén az adaxiális és abaxiális felszínek eltérő fokú viaszoltsága nem azonos mértékü leoldott viasztömeget eredményezhet (Riederer és Müller, 2006). Azonban a kutikuláris viaszok oldószeres extrakciója nem tud különbséget tenni az epikutikuláris és az intrakutikuláris viaszok között. Erre a problémára szolgáltattak egy ötletes megoldást egy 2012-es publikációban (Chatterjee et al., 2012), mely 
során az epikutikuláris viaszokat előzetes arabmézga bevonatba ágyazva tudták leszedni paradicsom termések felszínéről, a hátrahagyott viaszok pedig intrakutikuláris viaszoknak voltak tekinthetők. A tapasztalatok szerint számottevő különbségek mutatkoznak az epikutikuláris és az intrakutikuláris viaszok komponensei között. Az epikutikuláris viaszkomponensek között szabad zsírsavak és alkánok találhatóak, míg az intrakutikuláris viaszokban VLCFA alifás viaszkomponensek, primer alkoholok és triterpenoidok valamint egyéb ciklikus viaszkomponensek a jellemzőek (Buschhaus és Jetter, 2011). Éppen e különbség adja a kétféle viaszréteg eltérő mikroszkópos vizsgálatának lehetőségét, azok eltérő polaritása révén. A viaszok minőségi analízise gázkromatográfiás módszerrel végezhető el, az egyes vegyületkomponensek pedig tömegspektrometriás vizsgálattal azonosíthatók. A viaszok legjelentősebb komponensei között a telített hosszú szénláncú zsírsavakból levezethető 20-34 szénatomszámú alifás aldehidek, primer és szekunder alkoholok, alkánok, ketonok és észterek szerepelnek. Ezek mellett számos egyéb, kevésbé jellegzetes komponens is feltünik, melyek lehetnek terpenoidok, flavonoidok vagy szterolok (Kunst és Samuels, 2003). A felsoroltak és az azokon túl megjelenő vegyületek gyakran mutatnak jellegzetes megjelenést egy-egy növénycsalád vagy nagyobb növényrendszertani egység tagjai között. Arabidopsis thaliana mah1 mutánsok hajtásainak felszíni viaszrétegének vizsgálatakor a diolok és ketolok hiányát és a szekunder alkoholok és ketonok drasztikus csökkenését találták, mely alapján a MAH1 enzimet az alkán-szekunder alkohol, illetve ketonokhoz, diolokhoz, ketolokhoz vezető anyagcsereút kulcsenzimeként nevezték meg (Wen és Jetter, 2009). Paradicsom termések vizsgálatakor a sztenderd viasz-komponensek mellett többek között szterolokat, $\alpha-, \beta-, \delta$ amirint és naringenin-chalcont azonosítottak (Bauer et al., 2004a), mely utóbbi egy másik vizsgálat szerint a paradicsom kutikulájának színezetét adja (Saladié et al., 2007). A fentebb említett paradicsommal kapcsolatos vizsgálatban nem csupán minőségi, hanem mennyiségi viaszanalízist is végeztek, melyhez 26 különböző paradicsomfajtát választottak, és érett piros állapotban végezték a méréseket. Átlagosan, a paradicsomok felületegységére vonatkoztatva $50 \mu \mathrm{g} / \mathrm{cm}^{2}$ mennyiségü viaszt találtak, melynek 29\%-a főként hosszú láncú szénhidrogén, 19\%-a főként hosszú láncú alkohol és triterpenol és 52\%-a a naringenin-kalkon. A viaszok fó komponensei a naringenin-kalkon, n-hentriakontán, $\delta$-amirin, n-nonakozán, $\beta$-amirin, $\alpha$ amirin és n-tritriakontadién voltak (csökkenő sorrendben). Egy kiválasztott fajtán az érés során is elvégezték az analízist, és azt találták, hogy a naringenin-kalkon, az alkének és alkénolok csupán az érés előrehaladtával jelentek meg, és bár a legtöbb komponens mennyisége változott az érés során, a triterpenolok állandó arányban voltak jelen (Bauer et al., 2004b). Paprika termések esetén egy másik vizsgálat alapján a viaszok összetétele hasonló 
volt: a viaszok 29\%-a n-alkán, izoalkán és aldehid, 61\%-a triterpén, köztük a paradicsomnál már említett $\alpha$-, $\beta$-, $\delta$-amirin, valamint n-alkánsavak, és csupán nyomokban találtak nalkanolokat és fitoszterolokat. Érdekes eredmény ugyanebben a vizsgálatban, hogy a szintén Solanaceae családba tartozó tojásgyümölcs termések vizsgálatánál a fenti arány megfordult: 77\%-os frakciót tett ki az n-alkánok, izoalkánok és aldehidek csoportja, és csupán 23\%-ban voltak jelen a bonyolultabb szerkezetü n-zsírsavak, n-alkanolok triterpenolok és szterolok (Bauer et al., 2004b). Ezen eredmények arra mutatnak, hogy egyértelmü következtetéseket gyakran még egy növénycsaládon belül sem tehetünk a kutikuláris viaszok összetételére vonatkozóan, még ha egy-egy komponens jelenléte specifikus is. Alma gyümölcsök kutikulájának vizsgálatáról már a XX. század első feléből is találunk adatokat: egyértelmüen elkülöníthetőnek találták az n-nonakozán, n-heptakozán, d-nonakozán-10-ol, n-triakontanol, n-oktakontanol és az n-hexakontanol vegyületcsoportokat (Chibnall et al., 1931). Egy modernebb módszerekkel végzett kutatás során aldehideket is sikerült az alma kutikuláris viaszokból izolálni, ugyanakkor ketonvegyületek nem jelentek meg a mintákban egyik vizsgált fajtánál sem, a szerzők egyúttal felhívják a figyelmet az egyes fajták viaszkomponensei közti számottevő különbségekre (Verardo et al., 2003). Fajták közti különbségekre élezi ki egy másik szerzőcsoport is az eredményeit, melyekben mind összetételben, mint pedig a viaszok mennyiségében és a viaszréteg vastagságában különbséget írtak le a vizsgált három belga almafajta között. A ‘Jonagold’, 'Jonagored’ egy csoportba voltak sorolhatók összetételüket tekintve, a fő viaszkomponensek az $\alpha$-farnezén, pentakozán, heptakozán, oktakozán és nonakozán voltak egy azonosítatlan komponens megjelenése mellett, ugyanakkor az 'Elstar' fajtában ugyanez az ismeretlen vegyület és az $\alpha$-farnezén nem voltak detektálhatók. ULO tárolás körülményei mellett végezték a vizsgálatokat és fény derült arra is, hogy a nyolcadik hónapra a 'Jonagold’ és 'Jonagored' az $\alpha$-farnezén, az ismeretlen komponens és a nonakozán mennyisége szignifikánsan lecsökkent. A kutikula vastagsága 'Jonagold’, ‘Jonagored’ és ‘Elstar’ sorrendben emelkedett szignifikánsan (Veraverbeke et al., 2001a). Egy párhuzamos vizsgálatban az 'Elstar’ fajta gyümölcsének durvább, viaszrepedéseket hordozó felszíne, illetve a közel rokon 'Jonagold’ és 'Jonagored’ fajták sima, egyenletes felszíne közti különbséget egy szekunder alkohol szerkezetü viaszkomponens, a nonakozán-10-ol 'Elstar’-beli hiányával és a másik két fajta viaszában nagy mennyiségben történő detektálhatóságával magyarázzák, és érdekes hasonlóságot vonnak a viasz felszíni tulajdonságai és az 'Elstar' nagyfokú, valamint a 'Jonagold’'Jonagored' kisebb mértékü vízvesztésnek való kitettségében. Érdekes eredmény volt továbbá, hogy a gázkromatográfiás adatok szerint az 'Elstar' fajtában a nonakozán-10-ol 
teljes hiánya a nonakozán és más alkánkomponensek kiemelkedően nagy koncentrációjával párosult. Az alkohol-típusú vegyületkomponensek a viaszok fényességét magyarázzák, míg az alkánok a kékes-viaszos megjelenéssel korrelálnak. Bár egyes szerzők a nonakozán-10-ol megjelenésével hozzák összefüggésbe a csőszerü epikutikuláris viaszkristályok megjelenését, ilyet az érintett fajtákban nem találtak (Veraverbeke et al., 2001b). Egy 1996-os vizsgálat során a viaszok hőhatásra való válaszát és az ezzel összefüggő kalcium-ionok felvételének változását tanulmányozták. Vizsgálatukban a kutikula azon felszíni repedezéseivel foglalkoztak, melynek már vizsgálatuk előtt is nagy szerepet tulajdonítottak. 'Golden Delicious' almáknál bizonyították, hogy a fejlődés előrehaladtával a repedések mennyisége és szélessége növekszik, a fejlődés mellett pedig a termesztésmód, az évjárathatás és a posztharveszt körülmények is befolyásolják a repedések kialakulását. A hőkezelés hatására az almák tömegük közel 0,5\%-át veszítették el naponta, mely nagyfokú vízvesztés a termés külső sejtrétegeiben nagyfokú ionfelhalmozódáshoz, például a $\mathrm{Ca}^{2+}$ ionok nagyobb fokú jelenlétéhez vezetett. A hőkezelés ugyanakkor változást idézett elő a kutikula struktúrájában és homogénebb állományúvá tette azt. A magasabb $\mathrm{Ca}^{2+}$ koncentráció, mely a hőkezelt almák viaszában és exokarpiális rétegében megfigyelhető volt, feltehetően szerepet játszott a héjbarnulás és a keserürothadás héjrendellenességek visszaszorulásában, mely elváltozások súlyosbodnak a $\mathrm{Ca}^{2+}$ ionok hiánya esetén (Lurie et al., 1996).

\subsubsection{A kutikuláris viaszok bioszintézise}

A kutikuláris viaszok bioszintézisében részt vevő enzimek számos szempont szerint csoportosíthatók, funkciójukat tekintve ismertek lánchosszabbítást végző elongázok, tiolos észtercsoportot hidrolizáló tioészterázok, redox reakciókat katalizáló reduktázok és oxidázok, karbonilcsoport eltávolítását katalizáló dekarbonilázok és acilcsoport transzportját ellátó transzacilázok (Jenks és Ashworth, 1999). Egy 2003-as in silico analízis során felderítették az acil-lipid metabolizmusban szerepet játszó géneket, illetve az ezzel összefüggésbe hozható EST-ket. A vizsgálat során 600 gént, és 3750 EST-t azonosítottak résztvevőként, ezen belül a kutikuláris viaszok és a kutin szintézise és transzportja összesen 161 gént és 1081 EST-t foglal magába (Beisson et al., 2003). A mai napig azonosított gének között azonban sok esetben olyan nagyfokú homológiát találtak, hogy egyazon génként, egymás szinonimájaként említik őket. Mivel azonban a rendelkezésre álló szakirodalomban található nomenklatúra gyakran nehezen összeegyeztethető, többen is megkísérelték a szinonim géneket összefoglalni a saját vizsgálatuk területén (például Joubés et al., 2008, Yephremov és Schreiber, 2005, Samuels et al., 2008), ezek összegzését az I. táblázatban mutatom be. 
I. táblázat: A kutikuláris viasz-bioszintézissel összefüggésbe hozható gének szinonimái

\begin{tabular}{|l|l|}
\hline Arabidopsis lókusz & Gén neve / szinonimok \\
\hline At5g57800 & CER3 / WAX2 / YRE / FLP1 \\
\hline At1g25450 & KCS5 / CER60 \\
\hline At1g68530 & KCS6 / CER6 / CUT1 \\
\hline At2g26250 & KCS10 / FDH \\
\hline At2g46720 & KCS13 / HIC \\
\hline At5g04530 & KCS19 / FAE1 \\
\hline At1g72970 & ACE / HTH /APB24 \\
\hline At4g00360 & ATT1 / CYP86A2 \\
\hline At2g45970 & LCR / CYP86A8 \\
\hline At5g10480 & PAS2 / PAP \\
\hline
\end{tabular}

A különböző viasz-bioszintézissel összefüggésbe hozható gének vizsgálata olyan mutáns növények segítségével kezdődhetett, melyek fenotipikusan eltérő viaszoltságot mutattak a vad típusú növényekhez képest. Ilyen mutánsokat leírtak árpában, lúdfüben, kukoricában és repcében is. Ezeket a mutánsokat árpában és lúdfüben eceriferum-ként (cer), kukoricában és repcében glossy-ként ismerik. Az árpa a fentiek közül ebből a szempontból a leginkább vizsgált faj, 85 cer lókusszal, Arabidopsis thaliana-ban 22 cer mutánst írtak le eddig. Ezen mutánsok mindegyike a vad típustól eltérő mennyiségü viaszoltságot produkál, eltérésekkel annak összetételében is. Pásztázó elektronmikroszkópos képalkotással bizonyították, hogy a felszíni viaszkristályaik vagy nagymértékű morfológiai változásokon estek át, vagy teljes mértékben hiányoznak. Az egyes viasz-komponensek bioszintézise a kloroplasztisz zsírsavszintéziséből vezethető le, mely az acetát láncának meghosszabbítását jelenti két szénatomonként. A kloroplasztisz sztrómájában működő zsírsav-szintáz komplex (FAS) müködésének eredményeként zajlik a C16, C18 zsírsavak de novo szintézise. A kloroplasztiszon belül három altípusa létezik a FAS komplexeknek, melyek a lánchossz specifitásában térnek el egymástól. Ezek a KASIII (C2-C4 specifitással), KASI (C4-C16 specifitással) és a KASII (C16-C18 specifitással), az egyes enzim-komplexek ennek megfelelően a lánckezdés után egymásnak adják tovább a szintetizált láncot (Kunst és Samuels, 2003). Újabb kutatások arra mutatnak, hogy a citoszólban az acetáton kívül egyéb vegyületek, mint a glükóz-6-foszfát, a foszfo-enol-piruvát, piruvát és malát éppoly 
számottevő szénforrásai a plasztidiális zsírsavszintézisnek, mint maga az acetát (Rawsthorne, 2002).

A viasz-komponensek bioszintézisének sematikus ábráját Kunst és Samuels (2009) nyomán án mutatom be.

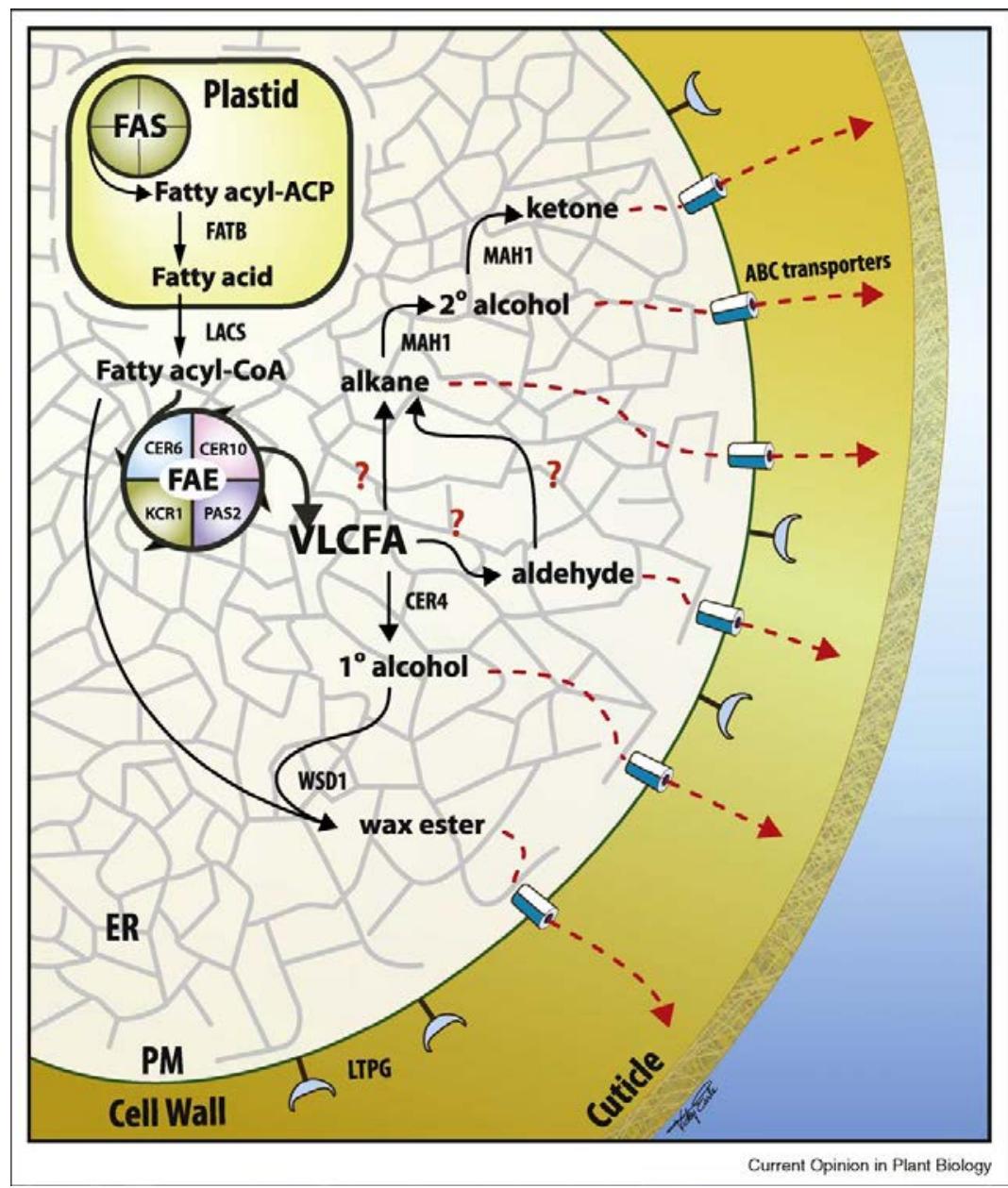

1. ábra: Viasz-komponensek bioszintézise, és a szintetizált komponensek transzportja a kloroplasztisztól a sejt felszínére (Kunst és Samuels, 2009).

A kész zsírsavlánc mérete a kloroplasztiszból kijutva az endoplazmatikus retikulumhoz kötött FAE (zsírsav-elongáz) enzimkomplex segítségével gyarapodik tovább, létrehozva a VLCFA-nak (nagyon hosszú zsírsav) nevezett vegyületcsoportot, C20-C34 lánchosszal. A növényi hosszú láncú zsírsavak főként telítettek vagy egyszeresen telítetlenek, ezzel nagyfokú eltérést mutatnak más, nem-növényi rendszerekhez képest, melyekben a többszörösen telítetlen zsírsavak (PUFA) kifejezetten elterjedtek (Leonard et al., 2004). Ezen többszörösen telítetlen vegyületek fontos szerepet játszanak a membránok fluiditásának és flexibilitásának alakításában, a növényi C18-as PUFA-k továbbá a jázmonsav és más 
oxilipinek szintéziséhez szükséges szubsztrátok (Wallis et al., 2002). A VLCFA-k létrejöttéhez azonban a kész C16/C18 vegyületnek el kell jutnia a kloroplasztiszból az endoplazmatikus retikulumhoz, melynek első lépése, hogy a plasztidiális szintézisben szerepet játszó acil-hordozó fehérjéről egy acil-ACP tioészteráz enzim leszakítja a zsírsavat majd az elszállítódik a plasztiszról és koenzim-A-vá észteresedik. Az acil-ACP tioészterázok két csoportját különítették el aminosav-szekvenciáik hasonlósága, illetve szubsztrát specifitásuk szerint, ezek az in vitro 18:1-ACP specifitást mutató FATA, valamint a föként telített zsírsavakra specifikus FATB tioészterázok (Riederer és Müller, 2006; Salas és Ohlrogge, 2002). A FATB mutáns növényekben a palmitinsav és a sztearinsav mennyiségének csökkenését írták le a különböző szervekben, mely kiegészült a növények csökkent növekedésével, a magok alacsony életképességével és megváltozott morfológiájával (Bonaventure et al., 2003).

A koenzim-A-vá történő észteresítést a LACS enzimek katalizálják, ezzel megnő a vegyületek citoplazmában való oldhatósága, valamint megszünik a plasztiszba történő visszakerülésük lehetősége. Lúdfüben kilenc LACS gént azonosítottak, melyek közül azonban csupán hét állította helyre a LACS deficiens mutáns élesztő növekedését. A legmagasabb aktivitást a LACS enzimek azon zsírsavak kialakításánál mutatták, melyek a fő szerkezeti és tartaléklipidek a lúdfü növényekben (Shockey et al., 2002). A LACS1 génről bebizonyították, hogy a LACS2-től eltérően nem a kutin, hanem a kutikuláris viaszok bioszintézisében játszik szerepet, együttes mutációjuk a kutikula számottevő változását és funkciócsökkenését, valamint jelentős szervfúziókat idézett elő (Weng et al., 2010). Emellett pedig a LACS1 zsírsavszintetáz aktivitással bírt a C20-C30 VLCFA-kra nézve, legmagasabb szinten a C30-as zsírsavakra (Lü et al., 2009).

A VLCFA-k szintézise négy enzimreakció: egy elongáció, egy redukció, egy dehidratáció és egy ismételt redukció egymást követő lépésével zajlik, és a belépő acil-csoport két szénatommal hosszabbodik a szintézis során, hasonlóan a zsírsavak kloroplasztisz-beli szintéziséhez. Az acil-lánc elongációjának kivitelezéséhez azonban kétszénatomos donormolekulák szükségesek. A kloroplasztisz zsírsavszintézisében ez a malonil-ACP, a FAE komplexben pedig a malonil-koenzim-A, a reakciót pedig az acetil-koenzim-A-karboxilázok (ACCáz) katalizálják (Riederer és Müller, 2006). Lúdfüben ezt a funkciót két gén, az ACC1 és ACC2 termékeinél írták le, és bár e két gén a kutatások szerint mindenütt kifejeződik, eddig csupán az ACC1 VLCFA lánchosszabbításban játszott szerepét bizonyították (Baud et al., 2003). A glossyhead (gsd1) mutánsban tárták fel az ACC1 egy mutáns allélját, amely meglepő 
módon kevésbé volt hatással a lipidmetabolizmus anyagcseréjére, mint a környezeti stresszválasz-útvonalakra, ezek közül is kiemelkedően a szeneszcencia és az etilén szintézisének determinánsaira. Ebböl arra következtetnek, hogy az ACC1 enzim által szintetizált citoszólikus malonil-koenzim-A-eredetü lipidek lényeges szerepet játszhatnak a stresszválaszok jelátvitelében (Lü et al., 2011). A kondenzációs lépést a KCS-ek (3-ketoacilkoenzim-A-szintáz), az első redukciót a KCR-ek (3-ketoacil-koenzim-A-reduktáz), a dehidratációt HCD-k (3-hidroxiacil-koenzim-A-dehidratáz), a végső redukciót pedig az ECRek (transz-2,3-enoil-koenzim-A-reduktáz) végzik. A VLCFA szintézis általában a kész C18 acil-koenzim-A-ból indul ki, bár bebizonyosodott, hogy a C16-koenzim--A is lehet a KCS enzimek szubsztrátja (Bach és Faure, 2010). A KCS-ek két alapvető típusát különböztetik meg, az élesztőben leírt ELO-típusúakat, valamint az Arabidopsis-ban jellemzett FAEtípusúakat (Kunst és Samuels, 2009). Az ELO-fehérjék erősen hidrofóbok, 5-7 transzmembrán doménnel a C- és az N-terminális régiókban egyaránt, ezzel szemben a KCS fehérjék egy membránkötő régiót tartalmaznak, mely kizárólag az N-terminális régióban található, és egy-két transzmembrán doménből áll (Leonard et al., 2006). Mindeddig három ELO-típusú, és huszonegy FAE-típusú KCS-t írtak le, a kutatások pedig valószínüsítik, hogy az egyes enzimek más-más lánchosszúságú szubsztrátspecifitással rendelkeznek, ezek pontos meghatározása azonban további vizsgálatokat igényel (Kunst és Samuels, 2009). Egy csupán a kondenzációs lépés enzimeivel, a KCS-ekkel foglalkozó kutatás során szintén bizonyították, hogy ezen enzimek mindegyike az ER-hez kapcsoltan müködik, továbbá meghatároztak nyolc alcsoportot a lúdfü KCS enzimcsoportján belül valamint azt is feltárták, hogy ezen enzimek a különböző növényi részekben jelentősen eltérő expressziós mintázatot mutatnak (Joubés et al., 2008). A feltételezések szerint a komplex a kondenzációs enzimekben nagyfokú eltérést mutathat, a másik három enzimről viszont azt feltételezik, hogy nem rendelkeznek a KCSekéhez hasonló nagyfokú szubsztrátspecifitással (Riederer és Müller, 2006). A KCS enzimek közül eddig csupán a CER6, a KCS2 és a KCS20 FAE-típusú KCS-ekről igazolták, hogy viasz-specifitással bírnak, és mindegyiknek a 22 szénatomos vagy annál hosszabb láncok kialakításában lehet szerepe Arabidopsis hajtásokban (Kunst és Samuels, 2009, Lee et al., 2009). A cer6 mutáns vizsgálata 1995-ig is visszanyúlik, amikor több más cer-mutánssal együtt a cer6 epikutikuláris viaszainak analízise is megtörtént, és a hajtásban a 26 szénatomos primer alkoholok, levélben pedig a 29 szénatomos alkánok felhalmozódását sikerült leírniuk, néhány egyéb, kevésbé major komponens megjelenése mellett (Jenks et al., 1995). Egy CER6 müködésében gátolt lúdfü vizsgálata során fény derült a teljes viaszmennyiség 6-7\%-ra történő visszaesésére, valamint a C24 termékek dominanciájára, amivel sikerült bizonyítani a 
CER6 C24 termékek hosszabbításában betöltött szerepét. Az enzimnek két feltételezett transzmembrán doménjét azonosították, és $\mathrm{N}$-terminális régiója egy másik ER-kapcsolt enzimével mutat hasonlóságot, melyből a korábban feltételezett endoplazmatikus retikulumhoz kapcsolt kifejeződés is bizonyítást nyert (Millar et al., 1999). Később beszámoltak arról is, hogy a gén expressziójához fény kellett, valamint hogy a sókoncentráció és a szárazság erősítette az expresszióját (Kunst et al., 2000). Egy újabb kutatásban, melyben kcs2/daisy és a kcs20 mutánsokat vizsgálták azt találták, hogy az egyes gének hiánya a teljes viaszmennyiség 15-20\%-os csökkenését idézi elő levélben és a hajtásban, a gének túlzott expressziója pedig 10-34\%-os növekedést idéz elő a levelek viasztartalmában (Lee et al., 2009). Az említett génekre nézve dupla mutáns növényeket összehasonlították az egyszeresen mutánsokkal is, és ez alapján levonható volt az a következtetés, hogy a KCS2/DAISY és a KCS20 a C22 VLCFA-k lánchosszabbításában redundáns szerepet játszanak, és expressziójuk ozmotikus stressz hatására eltérően változik. Az első redukciós lépést katalizáló KCR enzimek vizsgálata élesztőben kezdődött, és az ott leírt YBR159w génnek Arabidopsis thaliana-ban két homológját, az AtKCR1-et és az AtKCR2-t írták le. E gének közül az AtKCR1 génnek komplementált élesztő mutáns müködése normálisra állt vissza, ugyanakkor az AtKCR1 hiánya a lúdfü mutánsban embrionális letalitást okozott. Az AtKCR2 komplemtációja nem állította vissza az élesztő mutáns KCR funkcióját, ugyanakkor ez a lúdfü mutáns nem mutatott fenotípusos elváltozást. A KCR1 transzkriptumának redukciója majdnem teljes kutikuláris viaszveszteséget okozott, erős fiddlehead-re jellemző fenotípust idézve elő. A KCR1 knockdown mutánsokban mindezek mellett a gyökérszőrök és a laterális gyökérképződés, továbbá a C20 feletti telített zsírsavak szintézise gátolt volt (Beaudoin et al., 2009). Kukoricában leírtak egy mutánst, a glossy8-at, mely eltérő viaszoltsággal rendelkezett, és valószínűsítették, hogy a mutáns sérült Gl8 génje KCR funkcióval rendelkezhet (Xu et al., 1997), ennek bizonyítására azonban éveket kellett várni. A későbbiekben leírt és funkcionálisan jellemzett GL8-szerű gén, a GL8A és a GL8B egyaránt KCR funkcióval rendelkezik, és e két gén együttes mutációja embrionális letalitást idézett elő, ezzel azt is sikerült bizonyítani, hogy a kukorica KCR génjei nem csupán a kutikuláris viaszok bioszintézisében, hanem az embrionális fejlődésben is kulcsfontosságú szerepet játszanak (Riederer és Müller, 2006). A VLCFA szintézis FAE komplexében a dehidratációs lépést a kutatások szerint a PAS2 kódolja, mely génterméke az eddigi adatok szerint homológ az élesztő PHS1 dehidratáz enzimével. A PAS2 ugyanis képes volt visszaállítani a phs1 mutánsok citokinetikus defektusait, valamint a hosszú láncú szfingolipidek túlságos felhalmozódását. Ugyanakkor a PHS1 is képes volt a pas2 mutáns fejlődési elváltozásainak és 
a hosszú láncú vegyületek felhalmozódásának komplementálására. A pas2 mutáns a teljes VLCFA-tartalombeli csökkenéssel volt jellemezhető, és szoros kapcsolatot találtak a müködésében a CER10 ECR-funkciójú enzimmel. Mindezek mellett a PAS2 funckióvesztése embrionális letalitást okozott, és ez alapján megállapították, hogy lényeges és nélkülözhetetlen enzime a VLCFA bioszintézisnek (Bach et al., 2008). A FAE komplex utolsó, redukciós lépését katalizáló ECR funkciójú CER10 génnel kapcsolatos eredmények alapján arra következtetnek, hogy míg a felfedezett KCR és HCD funkciójú enzimek nélkülözhetetlennek bizonyultak a növényi fejlődés szempontjából, addig a CER10 hiánya viaszmennyiség és -minőség változást idézett elő, letalitást nem okozott, emiatt pedig feltételezhetően más enzimek is szerepet kaphatnak az utolsó redukciós lépésben (Zheng et al., 2005).

A VLCFA-k további átalakítása a sejten belül alapvetően két útvonalat követhet. Az acil-redukciós útvonalon a primer alkoholok és viasz-észterek keletkeznek, a dekarbonilációs anyagcsereúton pedig az aldehidek, alkánok, szekunder alkoholok és ketonok szintézise zajlik (Kunst és Samuels, 2003).

A primer alkoholok képződése, mivel további észteresítési reakciók résztvevői is, központi szerepet töltenek be a viaszok bioszintézisében, és több kutatás is foglalkozott a kialakulásukkal és modifikációjukkal (Jetter és Kunst, 2008). Jojobánál (Simmondsia chinensis) feltárták, hogy a növény hosszú láncú alkoholok és zsírsavak észtereit használja a magok energiatartalékainak növelésére, ellentétben a legtöbb növényfaj triacilglicerolt felhalmozó stratégiájával. A fejlődő embrióból sikeresen izoláltak egy alkohol előállítását katalizáló zsírsav-acil-koenzim-A-reduktáz (FAR) enzimet, melynek önálló kifejeztetése Escherichia coli-ban a zsírsavakat észteresítő alkoholok felhalmozódását, transzgenikus repcenövényekben pedig a szabad alkoholok mellett új viaszészterek megjelenését is okozta (Metz et al., 2000). A fenti génnel nyolc homológ gént írtak le Arabidopsis thaliana-ban, és a cer4 mutáns jellemzését követően a CER4 gént, melynek sérülése a hajtás viasztartalmát jelentősen megváltoztatta oly módon, hogy a primer alkoholok és viaszészterek mennyiségének nagyfokú csökkenése mellett kismértékü emelkedést tapasztaltak az aldehidek, alkánok, szekunder alkoholok és ketonok mennyiségében. A CER4 kifejeződése élesztősejtekben az ER-hoz kapcsoltan zajlik, a gén expressziója pedig a levelekben, a hajtásban, a virágzatban, a becőben és a gyökerekben is kimutatható volt (Rowland et al., 2006). Az acil-redukciós útvonal másik fö termékei, a viasz-észterek, számos ipari felhasználási lehetőséggel bírnak, emiatt is kiemelendő fontosságúak. Amellett, hogy az 
észterek főként az elsődleges hajtások felszínét borítják, a már említett sivatagi cserje, a jojoba magjának olajában is megtalálhatóak, amely növény az elsődleges forrása ezen észtereknek. 'Gala' fajtájú alma termések héjából származó epikutikuláris viaszokból is sikerült viasz-észtereket kimutatni, melyek monolignolok észtereinek bizonyultak (Whitaker et al., 2001). A viasz-észterek szintézisében szerepet játszó gén, a WSD1 jellemzése Arabidopsis thaliana növényekben történt, és bebizonyosodott, hogy ezen ER-hez kötődő enzim segítségével a C16 zsírsavak valamint a hosszú- és nagyon hosszú láncú primer alkoholok észteresítése történik (Li et al., 2008). Biotechnológiai eljárásokkal előállították a FAR és a WSD1 enzimek aktivitását együttesen mutató FAR-WS fúziós proteint, mellyel távlati lehetőségként megnyílt a viasz-észterek acil-koenzim-A-ból történő növénybeli előállításának biotechnológiai kapuja (Dittrich-Domergue et al., 2011).

A dekarbonilációs anyagcsereút reakcióiban az acil-redukciós úttal összevetve már több feltáratlan területet találunk. Az ezen az anyagcsereúton létrejövő vegyületek, mint az alkánok, aldehidek, szekunder alkoholok és ketonok mennyiségi/minőségi változásai a viaszkomponensként történő megjelenésükben a szintézisükért felelős génekről árulhat el információt. Számos eceriferum mutánst írtak le, melyek hajtásainak viaszaiban csökkent alkánmennyiséget találtak (Samuels et al., 2008), de ezen mutánsok viaszkomponenseinek komplexebb vizsgálata is megtörtént már (Jenks et al., 1995, Rashotte et al., 2001, Lai et al., 2007), így azok komponensek-szerinti elkülönítése lehetségessé vált. Az összes eceriferum mutáns közül a cer1 számít a legtöbbet kutatottnak, és a legnagyobb irodalmi háttérrel rendelkezőnek. 1995-ben izolálták magát a CER1 fehérjét, és megállapították, hogy dekarboniláz funkcióval bír, és a hosszú láncú aldehidek alkánná alakítását katalizálja (Aarts et al., 1995). Sikeresen bizonyították azt is, hogy a CER1 gén főként az epidermális szövetekben expresszálódik , és túltermeltetése a páratlan számú alkánok és a izomereinek felhalmozódásához vezet. Emellett sikerült bizonyítani ozmotikus regulációját, valamint azt, hogy szabályozásában az abszcizinsav játszhat kulcsszerepet. A CER1-et túltermelő növények csökkent kutikuláris permeabilitást mutattak, és kevésbé voltak kitéve a talajnedvesség csökkenésének, amellett hogy nagyobb fogékonyságot mutattak különböző bakteriális és gomba patogének fertőzésére (Bourdenx et al., 2011). Az eceriferum mutánsok között a közelmúltig vitatott szerepü volt a cer2. A cer2 génről mára bebizonyították, hogy a FAE komplex része, és a C28 lánchosszúság feletti zsírsavak képzésében vesz részt (Haslam et al., 2012). A gén expressziója a sztóma zárósejtekben, a trichómokban és a levélnyélben mutatható ki (Xia et al., 1997). Az aldehid-alkán átalakulás enzimeként tartják számon a 
CER1 mellett a CER22-t is, melynek sérülése következtében a C30 aldehid, a triakontanal C29 alkánná, n-nonakozánná alakulása kerül gátlás alá. A cer1-től eltérően a cer22 mutánsban nem találtak jelentősen megváltozott primer alkohol-tartalmat a viaszokban, a viasz-észterek mennyisége azonban a vad típusének 300\%-a lett (Riderer és Müller, 2006). Korábbi feltételezések szerint a WAX2 fontos szerepet játszik a kutin bioszintézisében a hiánya esetén bekövetkező szervfúziók kialakulása miatt, és mivel a wax2 mutáns megváltozott viasz-összetétellel bírt, a viasz-bioszintézis fontos szereplőjének tekintették (Chen et al., 2003). A kutin bioszintézisében betöltött szerepét azonban valamelyest cáfolta egy 2007-es közlemény, melyben egy eceriferum mutáns génjét, a CER3-at a WAX2-vel (syn.: YRE, FLP1) megegyezőnek találták, és nem találtak eltéréseket a kutin mennyiségében vagy összetételében (Rowland et al., 2007). A CER3 expressziójának szabályozását érdekes módon egy másik eceriferum mutáns a cer7 vizsgálata tárta fel, a CER7 fehérje ugyanis egy élesztő ribonukleázzal, az RRP45p-vel homológ, amely a CER3 expresszióját szabályozni képes (Hooker et al., 2007). A dekarbonilációs útvonal két másik lépését, az alkánok szekunder alkoholokká, majd ezen szekunder alkoholok ketonokká történő alakítását eddigi ismereteink szerint a MAH1 enzim katalizálja (Kunst és Samuels, 2009), és müködése az ER-hez kapcsolódva zajlik (Jetter és Kunst, 2008).

Egyéb komponensek is találhatók azonban a növényi kutikuláris viaszokban, melyek szintézise a fentebb részletezett folyamatok módosulásai révén jöhetnek létre. Eucalyptus, Festuca, Agropyron fajokban fö komponensként, Dianthus, Rhododendron fajokban, valamint több gabonában, így búzában, zabban, árpában és rozsban kimutatható komponensként jelentek meg $\beta$-diketonok, melyek alkalmanként, így például Agropyron-nál, Eucalyptus-nál és árpánál kiegészült alkán-2-olok megjelenésével is. Ezen vegyületek a FAE komplex enzimeinek és poliketid szintázok együttes müködésének a termékei, kutatásuk és a velük kapcsolatos eredmények eddig csupán a cer-cqu mutánsok vizsgálata révén történhetett (Riederer és Müller, 2006). A fenti két nagyobb vegyületcsoport mellett harmadikként a triterpenoidok csoportja említhető, az ide tartozó vegyületek változatos szerkezetükkel és funkciós csoportjaikkal teszik számottevővé a triterpenoid csoportot. A terpenoidok bioszintézisének modern kori kutatása Leopold Ruzicka nevéhez füződik, az 1950-es években megfogalmazott biogenetikus izoprén szabállyal jellemezte többek között a triterpenoidok vázát felépítő bioszintetikus utakat. A növényi szteroidok például a 2,3-oxidoszkvalén enzimatikus ciklizálódásával szintetizálódnak, a vegyület teljes átalakulását pedig egy enzim, egy triterpén szintáz katalizálja. Ezen enzimek általában egy fő terméket szintetizálnak, mára 
azonban biotechnológiai eljárásokkal sikeresen tudtak egy $\beta$-amirin-szintáz enzimet lupeolszintázzá alakítani. A fentieken kívül még egy termék-specifikus triterpén-szintázt ismerünk, melyet Luffa cylindrica-ból izoláltak, ez pedig egy izomultiflorenol-szintáz (Riederer és Müller, 2006). A kutikuláris viaszokból származó triterpenoidok táplálkozástudományi jelentősége mára már jól ismert. Alma héjból származó fő triterpenoid komponensek az oleánolsav és az urszolsav, ezek pedig néhány más, kevésbé major triterpenoid komponenssel együtt a kutatások szerint lényeges szerepet játszanak különböző daganatos megbetegedések, mint például a tüdőrák, májrák, mellrák és vastagbélrák kialakulásának megakadályozásában, a metasztázisos tumorsejtek növekedésének gátlásában. Más gyümölcsök és zöldségek kutikuláris viaszából izolált triterpenoidok is szerepet kapnak az egészségmegőrzésben: a szőlőbogyók oleánolsavai bizonyítottan rendelkeznek antimikrobiális, szklerózis-multiplexellenes, szív- és májvédő, valamint inzulintermelést fokozó hatással. De említhetők emellett a paradicsom vagy paprika termések viaszaiban található gyulladáscsökkentő, antidepresszáns és antiallergén hatású amirinjei vagy akár a grapefruit gyümölcsének fogyasztásra alkalmatlan héjából származó gyulladáscsökkentő hatású friedelin nevü vegyület is (Szakiel et al., 2012).

\subsubsection{A kutikuláris viaszok bioszintézisének szabályozása}

Számos tényezőt azonosítottak, melyek szoros kapcsolatban vannak a kutikuláris viaszok bioszintézisével, mi több, képesek is szabályozni azok szintézisét. Arabidopsis thaliana virágzati szárak gyors megnyúlása során például a felszíni viaszok mennyisége állandó, melyből a viaszok bioszintézisének a felület növekedésével való egyenes arányossága következik. Különböző vízhiányos stresszeknek kitéve lúdfü növényeket, a felületegységre vonatkozó viaszok mennyisége több mint kétszeresére emelkedett, elsődlegesen a közel négyszeres mennyiségre növekedett alkánok mennyiségének változása volt számottevő (Kosma et al., 2009). Szárazságstressz és a kutikuláris viaszok mennyiségének korrelációját vizsgálták cserjés dohány (Nicotiana glauca) esetén is. Három periodikus szárítást követően megnőtt az összes kutikuláris viaszmennyiség, és egy lipid transzfer protein (LTP) gén transzkriptumainak mennyiségének háromszoros emelkedését is sikerült kimutatni (Cameron et al., 2006). A cer2 és cer6 gének transzkripciója a fejlődés során szabályozás alatt van, a cer6 transzkripciója ezen felül fénnyel és ozmotikus stresszel indukálható. Ezzel szemben a cer2 gén expresszióját a fény, hő, hideg, sebzés faktorok egyike sem befolyásolja. A cer2 génről újabb eredmények azt mutatják, hogy közeli homológjával, a cer26-tal együtt a feltételezések szerint részt vesz a FAE-komplex működésében, előbbi a lúdfü virágzati szárára, utóbbi a levelére mutat szöveti specifitást (Joubés et al., 2011, Pascal et al., 2013). A 
környezeti hatások viasz-bioszintézisben betöltött szerepe igen szembeötlő, a konkrét transzkripciós faktorok részvételéről azonban kevés az ismeretünk. A MYB96 transzkripciós faktor például szárazságstressz hatására fokozza a viaszok termelődését, amely által növeli a lúdfü növény szárazságtoleranciáját (Seo et al., 2011). A MYB96 gént konstitutívan expresszáló növényvonalban a FAE komplexhez tartozó gének mellett a CER3, CER4 és WSD1 gének is megnövekedett müködést mutattak, de a viasz- és kutin-transzport funkciót ellátó lipid transzfer proteineket kódoló gének és a WBC11 expressziója is nagyobb volt (Seo és Park, 2011). A WIN1 (syn.: SHN1) transzkripciós faktorról sikeresen bizonyították, hogy befolyásolja a viaszok bioszintézisében szereplő CER1, KCS1 és CER2 gének müködését (Broun et al., 2004), de a viaszok mellett a kutin bioszintézisében is kulcsszerepet játszó LACS2 gén expresszióját is szabályozza (Kannangara et al., 2007).

\subsubsection{A kutikuláris viaszok transzportja}

A sejten belüli viasz-bioszintézis a kloroplasztiszban történő C16-C18 vegyületek szintézise után az ER-hez kapcsoltan történik. Innen szükséges a szintetizált termékek elszállítása a plazmamembránhoz, onnan pedig ezek további szállítása szükséges a kutikulához. A plazmamembránhoz történő intracelluláris transzport vizsgálata azonban sajnos ma még nem kivitelezhető, mivel az erre feltételezhetően alkalmas elektronmikroszkópos technika minta-előkészítése során a lipofil vegyületek extrakciója is megtörténik, így nehézzé válik a sejten belüli, transzportban esetleg szerepet játszó struktúrák azonosítása. Két vezető elméletet dolgoztak azonban ki az intracelluláris transzport modellezésére: az első elmélet szerint a Golgi-apparátus közvetít az ER és a plazmamembrán között, a másik viszont közvetlen transzportot feltételez. Mindkét elmélet alátámasztására rendelkezésre állnak eredmények, egyiket sem tartják azonban annyira meggyőzőnek, hogy egyértelmüen választ adhasson a kérdésre (Samuels et al., 2008). Bármely elméletet erősítik is meg későbbi kutatások, a plazmamembránhoz érkezett viasz-komponensnek át kell jutnia a kettős lipidrétegen, majd onnan további transzportja szükséges a sejtfalon keresztül a kutikulához. Két gén termékéről, a CER5 és a WBC11-ről bizonyították eddig sikeresen, hogy ATP-kötő kazetta transzporter (ABC-transzporter) funckióval bírnak. A transzporterek a virágzati szár epidermisz sejtjeinek plazmamembránjában voltak lokalizálhatók, és a mutánsok csökkent felszíni viaszmennyiséggel, de intracelluláris viaszfelhalmozódással voltak jellemezhetők (Samuels et al., 2008). Az eddigi kutatások alapján az ABCG11 (szin.: WBC11) és az ABCG12 a plazmamembránba ágyazódva heterodimert képezve együttesen segítik a kutikuláris viaszok transzportját, míg az ABCG11 egy másik, eddig ismeretlen 
ABCG fehérjével heterodimert alkotva segíti a kutin prekurzorok kutikulához jutását (Bird, 2008). A plazmamembránon való átjutást a hidrofil sejtfalon való átjutás követi, és ehhez a kutatók különböző lipid transzfer proteinek (LTP-k) szerepét valószínűsítették. Ezen fehérjék ugyanis az epidermiszben is szintetizálódnak, az apoplaszt irányába történik a szekréciójuk, elég aprók a sejtfal pórusain keresztül történő mozgáshoz, és rendelkeznek egy hidrofób résszel, mellyel a hosszú láncú lipidek kötése megvalósulhat. Ezen kedvező tulajdonságaik ellenére sem sikerült a legtöbb LTP-ről bizonyítani, hogy szerepet játszana a lipid transzportban (Samuels et al., 2008), jóllehet a bioszintézisükért felelős közel tizenöt génből álló LTP géncsalád felfedezése és jellemzése már megtörtént (Arondel et al., 2000). Az LTPG-ről azonban, mely egy glikozil-foszfatidil-inozitol-kapcsolt lipidtranszfer protein, néhány évvel ezelőtt sikerrel bizonyították ezt a tényt (DeBono et al., 2009).

\subsection{A kutikula bioszintézisében szerepet játszó gének expressziójának vizsgálata különböző növényi szövetekben}

A fentebb említett kutatások során általában egy-egy gén jelenlétét, működését, szerepét tisztázták valamely modellnövény szöveteiben. Több esetben végeztek azonban génexpressziós vizsgálatokat egyszerre több gént vizsgálatba vonva, így várva komplex képet a kutikula komponenseit felépítő gének expressziójáról. Az egyik ilyen komplex eredményt Suh és munkatársai szolgáltatták lúdfü virágzati szár epidermiszének vizsgálatáról. Microarray technikával 1900 olyan gént azonosítottak, mely a virágzati szár epidermiszében erősebb működést mutatott, ezen belül pedig jelentős volt azon gének száma, melyek membránokkal kapcsolt, extracelluláris, stressz-függő vagy lipid metabolizmussal kapcsolatos fehérjét kódolnak, ez utóbbi csoport az összes transzkriptumok számának 15\%-át tette ki. A lipid metabolizmus génjei közül egy 85 génből álló alcsoportot tudtak elkülöníteni, melyek a viaszok és a kutin bioszintézisében játszanak szerepet (Suh et al., 2005). Paradicsom termésének vizsgálata során héjspecifikus expressziót mutató géneket kerestek, és az azonosított 574 transzkriptum 17\%-át tudták besorolni a kutikuláris komponensek metabolikus folyamatait szabályozó gének közé. A fenilpropanoid/flavonoidok bioszintézisével kapcsolatos gének 6\%-ot, a zsírsav metabolizmus génjei 8\%-ot, a viaszok és a kutin bioszintézisének génjei 3\%-ot tettek ki. Ezek mellett jelentős része a transzkriptumoknak (28\%) az ismeretlen funkciójúak közé került besorolásra (Mintz-Oron et al., 2008). Szintén microarray technológiát használva meghatározták az alma termések fejlődése és érése során bekövetkező génexpresszió-beli változásokat. A vizsgálatokat a 'Fiesta' fajtán végezték, és a legmagasabb expressziós szinteket augusztus és szeptember 
hónapban találták. Az eredmények tárgyalásakor azonban sajnálatos módon nem tértek ki külön kutikuláris lipidek bioszintézisére, csupán nagyobb anyagcsere-folyamatok kategóriái szerepelnek (pl. primer metabolizmus, szekunder metabolizmus) (Soglio et al., 2009). Kereskedelmi jelentőségének ellenére mindmáig nem sikerült átfogó képet alkotni az alma termések kutikulájának kialakításában szerepet játszó génekről. A terméshúsa és az alma levél és virágok összevetésében publikáltak microarray eredményeket (Janssen et al., 2008, Lee et al., 2007) vagy éréssel összefüggő géneket vizsgáltak ugyanezzel a módszerrel (Costa et al., 2010). Egy német kutatócsoport reverz transzkripciós kvantitatív PCR technika segítségével vizsgálta a kutikula kialakításában szerepet játszó gének expresszióját a 'Regina' cseresznyefajtánál. A fejlődés korai szakaszában, a kutikula mennyiségének nagyfokú emelkedése mellett erősebb expressziós jelet találtak a WINA, WINB, ATT1, LACS2 gének esetén, míg a fejlődés előrehaladás során nagyfokú, de jelentős változást nem mutató expressziót mutattak a CER1, FATB, CER5, WBC11 gének (Alkio et al., 2012). 


\section{CÉLKITÜZÉS}

Az alma kutikulájának vizsgálata azért került kutatásunk középpontjába, mert az alma a kertészeti termesztés egyik meghatározó növénye Magyarországon. Gyümölcse általában hosszú idejü tárolás után kerül értékesítésre, tárolhatóságát az apadás befolyásolja. Az apadás a kutikulán keresztül történő vízvesztés, amit a kutikula összetétele és struktúrája nagy valószínüséggel befolyásolnak.

- A vizsgálatainkat molekuláris és növényélettani paraméterek meghatározásával kívántuk végrehajtani. In silico meg kívánjuk keresni azon géneket, melyek szerepet játszhatnak a kutikuláris struktúrák kialakításában, és célul tüztük ki ezen gének expressziós vizsgálatát. Ezek az eredmények később nemesítési programokban felhasználható lehetnek.

- Ehhez egy megbízhatóan müködő, referenciaként szolgáló kontrollrendszert is ki szeretnénk alakítani, mely kontrollgénekkel a génexpressziós vizsgálataink eredményei egzakt módon kvantifikálhatók lesznek.

- Mindezek mellett célul tüztük ki a termések betakarítását követő vízvesztés vizsgálatát is, valamint a termés exokarpiumának és kutikulájának fénymikroszkópos, és az esetleges ultrastrukturális eltérések felderítésére konfokális lézer pásztázó mikroszkópos vizsgálatát is.

A paprika egy másik kiemelt jelentőségü kertészeti termék Magyarországon. A termesztett paprika egy részét szárított őrleményként értékesítik, így vízvesztésének közvetlen gazdasági jelentősége is van. A paprika termés kutikuláris paraméterek által kialakított tulajdonságainak vizsgálata azért jelentős, mert a termést nem borítják sztómák, így a párologtatás legszámottevőbb szabályozója maga a kutikula.

- Célunkként határoztuk meg a termések posztharveszt párologtatásának vizsgálatát különböző fajtákon és érettségi állapotokban, így a kutikula szerepének fejlődés során történő esetleges változásait is azonosíthatjuk. A kutikula szerepét indirekt módon, annak eltávolításával bizonyíthatjuk, ezért egy olyan kezelt csoporttal kívánjuk eredményeinket összevetni, mely tagjait kutikularétegüktől megfosztunk. 
- Meg kívánjuk határozni a felületi viaszréteg tömegét, és konfokális lézer pásztázó mikroszkópos mérések segítségével esetleges ultrastrukturális különbségeket kívánunk keresni különböző fajtájú paprikák kutikulájában. 


\section{ANYAG ÉS MÓDSZER}

\subsection{Növényanyag}

\subsubsection{Növényanyag-paprika}

A vizsgálatainkhoz használt paprikák a Capsicum annuum L. 'Titán’, 'Hó’ és 'Kárpia' fajtái voltak, melyeket Dr. Terbe István bocsátott rendelkezésünkre. A növényeket a BCE Soroksári Kísérleti Üzem és Tangazdaságában termesztették hidropóniás módszerrel Grodan kőzetgyapoton, a gyártó által ajánlott tápanyag-utánpótlással. A ‘Hó’ és ‘Titán’ fajtákat érintő vizsgálathoz a növények terméseit három eltérő fejlődési fázisban szedtük, ezek kereskedelmi definíciókkal meghatározva a félméretű (a fajtára jellemző kereskedelmi/szedési érettségi állapotban lévő paprika méretének fele), éretlen és érett (szedési érettség) állapotok voltak, az állományt 2010. április elején ültették ki. Minden növényt két fő szárra történő visszametszést követően vezettek fel, majd a fö- és oldalhajtásokon két-két termésre metszették vissza őket. Az állomány biológiai növényvédelem alatt állt, tíz naponta szedték a terméseket és a letermett ágakat ezt követően visszametszették.

A vízvesztéses kísérletet két ismétlésben végeztük: első alkalommal 26 'Titán’ és 24 'Hó' paprikát, a második során pedig mindkét fajtából 45 paprika termést osztottam szét kezelések illetve érettségi állapotok szerint az II. táblázat szerint. 
II. táblázat: A ‘Hó’ és ‘Titán’ paprikák vizsgálatához elkészített kísérleti elrendezés

\begin{tabular}{|c|c|c|c|c|}
\hline & & & ‘Hó’ termések (db) & $\begin{array}{l}\text { ‘Titán’ termések } \\
\text { (db) }\end{array}$ \\
\hline \multirow[t]{6}{*}{ 1. mérés } & \multirow[t]{3}{*}{ Kezelt } & Félméretü & 4 & 4 \\
\hline & & Éretlen & 4 & 4 \\
\hline & & Érett & 4 & 4 \\
\hline & \multirow[t]{3}{*}{ Kontroll } & Félméretü & 4 & 6 \\
\hline & & Éretlen & 4 & 4 \\
\hline & & Érett & 4 & 4 \\
\hline \multirow[t]{6}{*}{ 2. mérés } & \multirow[t]{3}{*}{ Kezelt } & Félméretü & 7 & 7 \\
\hline & & Éretlen & 7 & 7 \\
\hline & & Érett & 7 & 7 \\
\hline & \multirow[t]{3}{*}{ Kontroll } & Félméretü & 8 & 8 \\
\hline & & Éretlen & 8 & 8 \\
\hline & & Érett & 8 & 8 \\
\hline
\end{tabular}

A ‘Hó’ és ‘Kárpia’ fajták vizsgálata szintén két ismétlésben történt, a szedésekre 2011. júliusában és augusztusában került sor, az állományt a korábbiakban leírtak szerint kezelték. A kísérlet során teljes érettségi állapotú terméseket mértünk, az elrendezést az III. táblázatban mutatom be.

III. táblázat: A ‘Hó’ és ‘Kárpia’ paprikák vizsgálatához felhasznált termések

\begin{tabular}{|c|l|l|}
\cline { 2 - 3 } \multicolumn{1}{c|}{} & $\begin{array}{l}\text { 'Hó' termések } \\
(\mathrm{db})\end{array}$ & $\begin{array}{l}\text { 'Kárpia' termések } \\
(\mathrm{db})\end{array}$ \\
\hline 1. mérés & 19 & 20 \\
\hline 2. mérés & 15 & 15 \\
\hline
\end{tabular}

\subsubsection{Növényanyag-alma}

A vizsgálatokhoz szükséges Malus x domestica Borkh. 'Gegesi zöld', 'Prima' és 'Florina’ fajtájú gyümölcsöket Dr. Tóth Magdolna bocsátotta rendelkezésünkre. Az almák a BCE Soroksári Kísérleti Üzem és Tangazdaságából származnak, az ültetvényben 4x1, illetve 
3,6x1-1,2 m-es sor- illetve tőtávolságot, huzalos- illetve egyedi karós támrendszert, karcsúorsó koronaformát valamint mikroszórófejes öntözést alkalmaznak. A fajták M9-es alanyon nőttek, varasodásra rezisztensek, így növényvédelmük elsősorban kártevők (főleg almamoly) ellen zajlott.

A kísérleti körülmények optimalizálásához a 'Gegesi zöld' fajtát választottuk, a terméseket a Gyümölcstermő Növények hütőtárolójából kaptuk. A megérkezésüket követően azonnal elválasztottuk a terméshéj és hús szövettáját egymástól (lásd Totál RNS izolálás fejezet), és Falcon-csövekben $-80{ }^{\circ} \mathrm{C}$-ra helyeztük őket a felhasználásig.

A 'Florina' fajta levélrügyéből, illetve a 'Florina' és 'Prima' fajták leveléből, a terméshúsából illetve héjából vontunk ki totál RNS-t. A kísérletekhez különböző érettségi állapotban gyüjtöttünk mintákat, melyek összegzését az 1. ábra mutatja, a levélrügy mintákat 2010 áprilisában gyüjtöttük. 2010-ben a mintavétel időpontjai VII/15., VIII/21. és IX/16. voltak, 2011-ben pedig VII/05., VII/21., VIII/23. és IX/16. voltak.
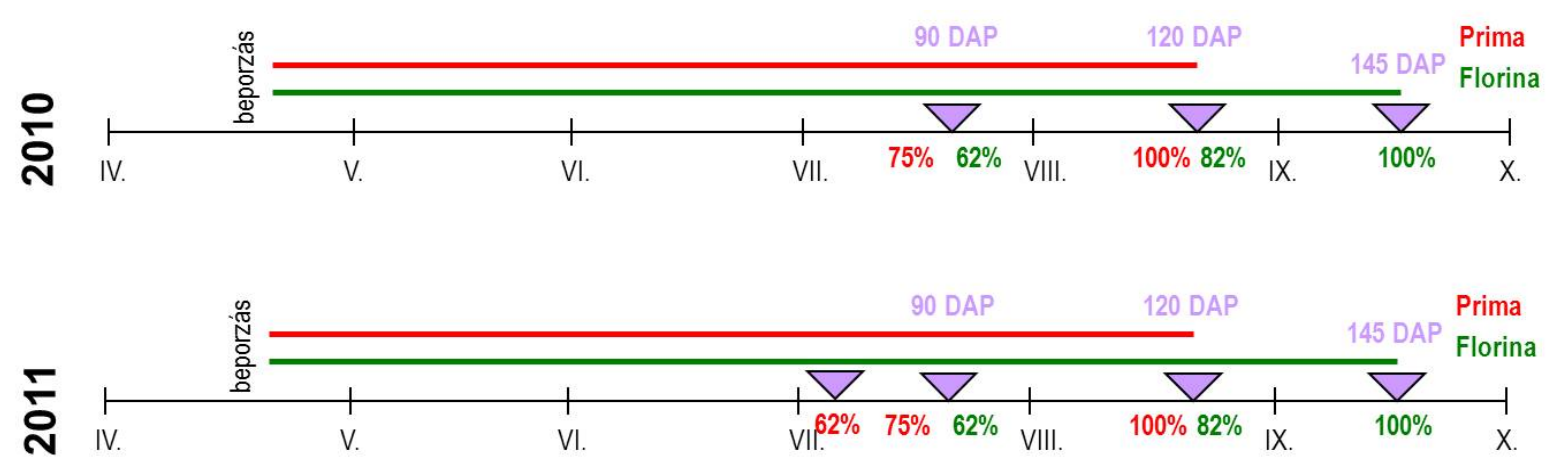

1. ábra: Alma mintagyüjtések időpontjai (lila jelölők) a beporzást követő napok fényében. A betakarítások időpontjait 100\%-nak, a mintagyüjtések időpontjait a beporzástól számított napok betakarításhoz viszonyított, százalékban kifejezett értékeiként feltüntetve.

A levél szövetekből mindkét évben 120 DAP állapotban gyüjtöttünk mintát, lehetőség szerint minél fiatalabb leveleket választottunk. A leszedésüket követően még a helyszínen 50 ml-es Falcon-csövekbe helyeztük őket, majd folyékony nitrogénben fagyasztva szállítottuk és felhasználásukig $-80{ }^{\circ} \mathrm{C}$-on tároltuk. A terméseket a totál RNS izoláláshoz mindkét évben szedési érettségi állapotban gyüjtöttük be, melynek meghatározását a BCE soroksári Kísérleti Üzem és Tangazdaságának munkatársai végezték, és az általuk megjelölt időpontban történt a mintagyüjtés. A szedést követő egy órán belül a terméshéj át elválasztottuk a hústól és folyékony nitrogénben fagyasztást követően $-80{ }^{\circ} \mathrm{C}$-on tároltuk a felhasználásukig. 


\subsection{Vízvesztés meghatározása}

A paprikák vízvesztését a tömegük és felszínük mérésével határoztuk meg, 100\%-os érettségi állapotban, két ismétlésben. A ‘Titán’ -’Hó’ összevetésben 10-10, a ‘Kárpia’ -’Hó’ esetén 11-13 napon keresztül mértük a paprikák tömegét egy SARTORIUS MC1 Analytic AC 210 P mérlegen. A naponta csökkenő tömeget a perisztómásan elpárologtatott víznek tulajdonítottuk, ugyanis egyrészt a paprika termések felszínén nem találhatók sztómák, ezért a párologtatás kizárólag a kutikulán keresztül történhet, valamint alapozva Zsom Tamás doktori értekezésében közölt eredményekre elmondható, hogy a tömegvesztést befolyásoló elsődleges tényező a paprika és annak környezete közötti vízgőznyomás-különbség (Zsom, 2007).

A II. táblázatban leírtak szerinti csoportosítást követően a kezelt csoport terméseit egy percen keresztül $300 \mathrm{ml}$ kloroformba merítettük, majd hagytuk megszáradni. Az egyes csoportok oldószereit, mely már a paprikák felszínéről leoldott viaszokat is tartalmazták, $5 \mathrm{~g}$ vízmentes $\mathrm{Na}_{2} \mathrm{SO}_{4}$ segítségével vízmentesítettük, majd Albet 400 szürőpapíron átszürtük, így elválasztottuk a törmelékektől és a nátrium-szulfáttól, majd külön lombikokban tároltuk teljes bepárlásukig. Ezt követően a paprikák kocsányát vazelinnel kentük be, hogy az azon keresztüli vízvesztés kiküszöbölhetővé váljon és a paprikákat laboratóriumi körülmények között, $22{ }^{\circ} \mathrm{C}$ hőmérsékleten, 60-65\% relatív páratartalmú helyiségben tároltuk, naponta mérve a tömegüket. A napi vízvesztés jellemzésére Díaz-Pérez és munkatársai kidolgoztak egy mutatót, a WLR-t (water loss rate), amelyet a $W L R=\frac{\Delta F W}{F W_{0}}$ képlettel számoltunk ki, melyet kiegészítettünk a kísérlet teljes hossza alatt elvesztett tömegeket bemutató totál WLR meghatározásával, amelyet a TotalWLR $=\sum \overline{W L R_{1}, W L R_{2} \ldots W L R_{n}}$ képlettel számoltunk, ahol $\mathrm{n}$ az utolsó mérés napja, mindkét értékkel százalékosan tudtuk kifejezni a tömegveszteségeket (Díaz-Pérez et al., 2007).

Az alma vizsgálatához a termések tömegét a paprikához hasonlóan határoztuk meg, laboratóriumi körülmények között tárolva, felszínűket pedig gömbnek tekintve határoztuk meg $\left(A=4 \pi r^{2}\right)$, átmérőjüket három irányból megmérve, azokat átlagolva határoztuk meg. $\mathrm{A}$ kocsányokat ebben az esetben is vazelinnal kentük be, és az almák esetén is fokozattan ügyeltünk arra, hogy csak sérülésmentes, egészséges gyümölcsökkel dolgozzunk, a vizsgálat alatt betegség tüneteit mutató almákat eltávolítottuk a vizsgálatból. A méréseket csak a 2011es mintákon végeztük el, a mért tömegekből százalékos értékeket számoltunk, az első napi tömeget 100\%-nak tekintve, minden további nap tömegértékét pedig az első napiból kivonva, és a különbséget százalékban meghatározva. 


\subsection{Kutikuláris viaszok leoldása és vizsgálata}

Mind a paprika, mind pedig az alma esetén szerves oldószeres kutikuláris viaszleoldást végeztünk a kutikula viasztartalmának mennyiségi és minőségi analíziséhez. Az almáknál a kialakított csoportba tartozó almák méretétől függően 250, 300 illetve $350 \mathrm{ml}$ kloroformmal dolgoztunk, a beoldás további részletei a paprikánál leírtakkal egyeznek meg. A paprikákat a „Vízvesztés meghatározása” részben leírtak szerint kezeltük, a csoportonként előállított viasztartalmú kloroform oldatokat gömblombikokban gyüjtöttük össze. Gyepes Attila segítségével az oldatokat egy RotoVapor készülékben vákuumban $40{ }^{\circ} \mathrm{C}$-on bepároltuk, a visszamaradt viasztömegeket megmértük.

\subsection{Alkalmazott statisztikai módszerek}

Vizsgálataink során egy- illetve kéttényezős varianciaanalízist használtunk a kutikuláris vastagságok, illetve a paprikát érintő vízvesztéses vizsgálataink értékelésére, lineáris regressziót pedig az alma vízvesztéses vizsgálataihoz, a kivitelezéshez pedig a MS Excel, illetve a PASW18 programokat vettük igénybe.

A varianciaanalízis feltétele a szfericitásra a paprika WLR vizsgálatánál és egyes, felületegységre vonatkoztatott méréseknél sérült, ezért az adatsorok korrekcióját GreenhouseGeisser korrekció (Geisser és Greenhouse, 1958) segítségével, a 2011-es 'Hó’ -'Kárpia' összevetésnél pedig a szórások homogenizálására, illetve az eloszlás ferdeségének vagy csúcsosságának mérséklésére használható Box-Cox transzformációt alkalmaztunk (Box és Cox, 1964). Egyes vizsgálati csoportoknál a kiugró szórásértékek miatt homogenizálást hajtottunk végre, ehhez logaritmizálást alkalmaztunk. A kiértékelés során a minták normális eloszlását Kolmogorov-Smirnov teszttel ellenőriztük.

\subsection{Totál RNS izolálás}

A levélrügyek RNS izolálásához a Viogene Plant Total RNA Mini Kit-et használtuk, a cég által az RX pufferhez kapcsolt protokollt követve.

Az almák terméséből és leveléből származó teljes RNS-kivonat kinyerésére számos módszerrel próbálkoztunk (pl. Gasic et al., 2004 Hu et al., 2002), melyek közül számottevő (gélelektroforetikusan detektálható) mennyiségű RNS-t kizárólag az Asif és munkatársai által 2006-ban publikáltak szerint tudtunk kinyerni, módszereik közül is az etanolos extrakció módszerével (Asif et al., 2006). 
A vizsgálatunkhoz az almák leveleit, a termések héját illetve húsát választottuk ki, a leveleket a helyszínen fagyasztva, a gyümölcsöket a laboratóriumba történő beszállítást követően szövetek szerint elválasztva és 50 ml-es Falcon-csövekben fagyasztva. A terméshéj illetve a terméshús szövettájak feldolgozásakor fokozottan ügyeltünk arra, hogy ez a két szövettáj egymástól jól elkülöníthető legyen, azaz a hús szövettájba a héjból ne kerülhessen szövet, fordított esetben pedig minimalizáltuk a keveredést. A gyakorlatban ezt az elkülönülést mikroszkóppal is nyomon követtük több reprezentatív metszésen, melyeket a 2. ábrán mutatok be.

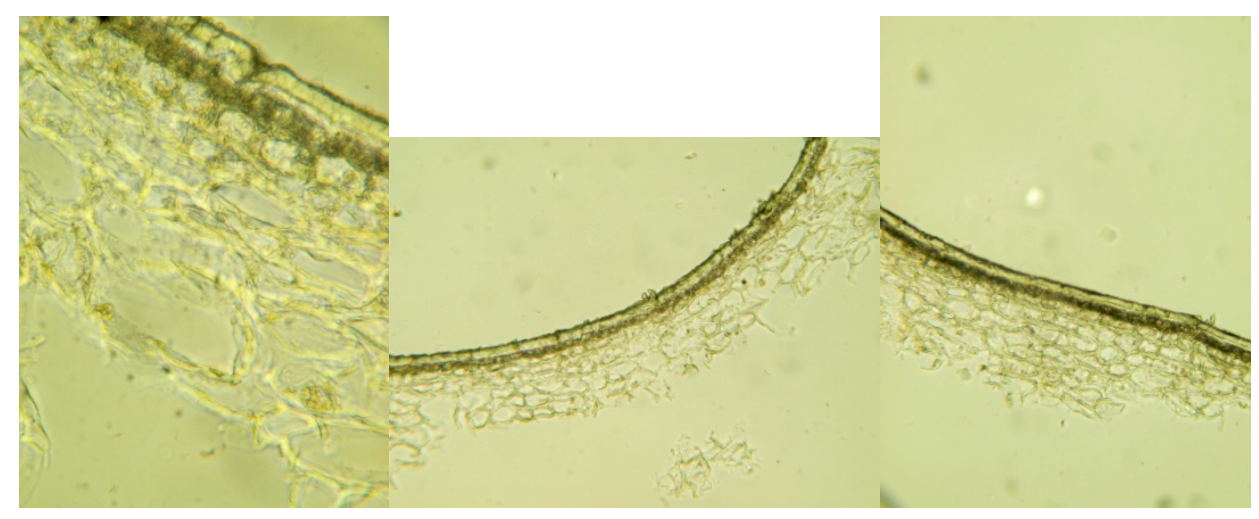

2. ábra: Az alma héjminták reprezentatív fénymikroszkópos képei a molekuláris vizsgálatokhoz felhasznált minták szöveti eredetének tisztázásához (10x, 20x nagítások, festés nélkül).

Jól látható a mikroszkópos képek alapján, hogy a héj szövettájnak nevezett mintába csupán az alma termések kutikuláris rétege, az exokarpium sejtrétegek, valamint az ez alatt található 610 parenchimális sejtsor került be. A metszeteket festés nélkül vizsgáltuk, a mikroszkópos vizsgálatok módszertanáról szóló fejezetben leírtak szerint.

Az RNS-kivonás során követtük az Asif és munkatársai által javasolt protokollt az alábbiakban részletezett módosításokkal. A szövetmintáink folyékony nitrogénben homogénné porítását követően azok 1 grammjához $10 \mathrm{ml}$ Solution 1 oldatot $(85 \%$ etanol, 0,1\% SDS, 0,1\% nátrium-tioszulfát mQ-vízben felvéve) adtunk, majd intenzív vortexelést követően centrifugáltuk 5000 rpm-en Hettich Mikro200R centrifugában (Hettich, Tuttlingen, Németország) 20 percig $4^{\circ} \mathrm{C}$-on. A felülúszót leöntve a csapadékot visszaoldottuk kiindulási grammonkénti $10 \mathrm{ml}$ Solution 2-ben (75\% etanol, 0,1\% SDS, 0,1\% nátrium-tioszulfát mQvízben felvéve), intenzív vortexelést követően a fentivel megegyezően centrifugáltuk. Ezt követően a csapadékot szövetgrammonként $10 \mathrm{ml} 65^{\circ} \mathrm{C}$-ra melegített extrakciós pufferben (100 mM Tris-HCl (pH 8), 1,4 M NaCl, 20 mM EDTA (pH 8), 2\% CTAB és 2\% merkapto- 
etanol) szuszpendáltuk, majd $65^{\circ} \mathrm{C}$-on inkubáltuk egy órán keresztül, 15 percenként óvatosan vortexelve. A minták szobahőmérsékletre hülése után 1:1 arányban kevertük kloroform:izoamil alkohol (24:1) keverékével, homogén szuszpenzió eléréséig vortexeltük a mintát, majd 20 percig 7800 g-vel centrifugáltuk szobahőmérsékleten. A centrifugálás után a vizes fázist egy új Falcon-csőbe pipettáztuk, majd ezt is 1:1 arányban kevertük kloroform:izoamil alkohol (24:1) keverékével, és szuszpenzióvá vortexelést követően az előzővel azonos körülmények között centrifugáltuk. Ezután a vizes fázist kipipettázva egy steril Falcon-csőbe 10 M LiCl-ot adtunk hozzá, hogy annak végkoncentrációja 3 M legyen. A mintákat 2 ml-es Eppendorf csövekbe szedtük szét, és egy éjszakán át $4{ }^{\circ} \mathrm{C}$-on tároltuk, majd 14500 g-vel centrifugáltuk előzetesen $4{ }^{\circ} \mathrm{C}$-ra hütött centrifugában, 20 percen át őket. A felülúszót eltávolítottuk, a csapadékot visszaoldottuk $500 \mu \mathrm{l} \mathrm{mQ}$ vízben, és 1:1 arányban fenolt adtunk hozzá (a fenol ekvilibrálását a Sambrook et al., 1989 által ajánlottak szerint végeztük el), és 10 percig centrifugáltuk 14500 g-n. A vizes fázist egy új csőbe pipettáztuk, és 1:1 arányú fenol-kloroform:izoamil alkoholt (24:1)adtunk hozzá, szuszpenzióvá vortexeltük, és a fentivel azonos módon centrifugáltuk. A vizes fázist ismét lepipettáztuk egy új csőbe, majd ahhoz 1:1 arányban kloroform:izoamil alkoholt (24:1) adtunk, intenzíven vortexeltük, és az előbb leírtak szerint centrifugáltuk. Az így kapott vizes fázist $1 / 10$ térfogatnyi $3 \mathrm{M}$ nátrium-acetát ( $\mathrm{pH}$ 5,2) és 3 térfogatnyi 96\%-os etanol jelenlétében - egy éjszakára $20^{\circ} \mathrm{C}$-ra helyeztük. Másnap egy 20 percig tartó $4{ }^{\circ} \mathrm{C}$-on történő centrifugálás után a felülúszót eltávolítottuk, a csapadékot $70 \%$-os $-20^{\circ} \mathrm{C}$-on tárolt etanollal óvatosan mostuk, majd ismételt, az előbbivel megegyező centrifugálást követően a felülúszót eltávolítottuk, és a csapadékot szárítottuk, majd $50 \mu \mathrm{l}$ mQ-vízben visszaoldottuk, és felhasználásig -80C-on tároltuk.

A kinyert RNS-ek mennyiségét és minőségét Shimadzu spektrofotométerrel, illetve NanoDrop készülékkel, továbbá gélelektroforetikusan is ellenőriztük, mely során 1,5\%-os agaróz gélen vizsgáltuk az RNS-kivonatot. Több esetben kaptunk azonban egymásnak ellentmondó eredményeket a gélképek illetve a spektrofotometriás értékek között, így végül a koncentrációk kiegyenlítését a gélképek alapján végeztük el. Ehhez azzal a feltételezéssel éltünk, hogy a spektrofotometriás mérések során nem csupán az intakt nukleinsavak, hanem annak részleges degradációja során keletkezett töredékek is jelen lehetnek, azok pedig hamisan emelik meg a nukleinsavak koncentrációját. Azon mintákat, melyeknél az A260/A280 arányt nem találtuk kielégítőnek (1,7 felett tekinthető a minta fehérjével nem szennyezettnek) külön e célból nem tisztítottuk tovább, mert a későbbi DN-áz kezelést követő fenol-kloroformos kicsapás során a minták fehérje tartalmát a módszer drasztikusan 
csökkenti, és megítélésünk szerint egy további, az RNS-kivonást közvetlenül követő fehérje kicsapásos és újbóli RNS visszaoldásos lépés jelentősen csökkenthette volna az egyébként sem jelentős mennyiségü totál RNS koncentrációt.

\subsection{Genomi DNS szennyeződésének ellenőrzése, DN-áz kezelés}

A kinyert totál RNS-kivonat genomi DNS szennyezettségét egy speciális primerpárral végzett PCR során ellenőriztük. Az EF1 primerpárt ugyanis úgy terveztük meg, hogy az amplifikált régióban a genomból származó DNS-en intron legyen jelen, amely azonban az RNS-ről készülő cDNS-en nem kimutatható. Ezek alapján pedig a két szakasz mérete szignifikáns különbséget fog mutatni a PCR-t követő gélelektroforetikus képen. A primer adatait az IV. táblázat mutatja.

IV. táblázat: Az EF1 primer adatai

\begin{tabular}{|l|l|l|l|}
\hline $\begin{array}{l}\text { Gén } \\
\text { neve }\end{array}$ & Szekvencia azonosítója & Forward és reverz primerek szekvenciái & $\begin{array}{l}\text { Termék } \\
\text { hosszúsága }\end{array}$ \\
\hline EF1for & $\begin{array}{l}\text { AJ223969 } \\
\text { (MDP0000297959) }\end{array}$ & 5’GCTCAAGGCTGAGCGTGAACGT & 398/596 bp \\
\cline { 1 - 2 } EF1rev & & 5’CAGAAATGGGGACAAA & \\
\hline
\end{tabular}

A genomi DNS jelenlétének kimutatására további primereket is terveztünk, így például egy aktinra (GO577606) illetve egy másik elongációs faktorra specifikus primert, azonban ezek jelentős szöveti specifitást mutattak, így későbbi vizsgálataink során elhagytuk öket.

A genomi DNS ellenőrzése után gDNS kontamináció esetén DN-áz I enzimmel (Fermentas, Vilnius, Litvánia) történő emésztést végeztünk a javasolt protokoll szerint, melyben a mért nukleinsav-koncentrációt úgy tekintettük, hogy annak fele genomi DNS szennyezés, a másik felét kalkuláltuk RNS-nek, mintánként eltérő mennyiségben. A genomi DNS szennyeződés feltételezett mennyiségének függvényében meghatároztuk a szükséges DN-áz enzim mennyiségét, majd e kettőből kiszámoltuk a szükséges puffer mennyiségét. Az enzimet fenol-kloroformos kicsapással távolítottuk el a mintánkból. Az emésztett mintákat 300 pl-re egészítettük ki mQ vízzel, majd 1:1 arányban adtunk hozzá fenolt, illetve kloroform:izoamil alkohol (24:1) keveréket, mindkét lépésnél a mintákat szuszpendáltuk, majd szobahőmérsékleten 14500 g-n centrifugáltuk. A kloroformozás utáni felülúszót 1/10 3 M nátrium-acetát ( $\mathrm{pH}$ 5,2) és 3 egység 96\%-os etanol jelenlétében 1 órán át $-80^{\circ} \mathrm{C}$-ra 
helyeztük, majd $4^{\circ} \mathrm{C}$-on, 20 percig, 14500 g-n centrifugáltuk. A csapadékot jéghideg 70\%-os etanollal mostuk, a fentivel azonos módon centrifugáltuk, majd szárítottuk. Az etanoltól mentes mintákat $50 \mu \mathrm{l}$-ben eluáltuk.

\section{7. gDNS-izolálás}

A kinyert totál RNS genomi DNS kontaminációjának ellenőrzésére genomi DNS-t is vontunk ki a Gegesi zöld terméshéj szövettájából a QIAGEN DNeasy Kit segítségével, a gyártó által adott protokollt követve. Az így nyert genomi DNS-t a későbbi PCR reakciókban EF1 és aktin primerekkel amplifikáltuk és vetettük össze a cDNS-ből amplifikált termékkel.

\subsection{RT-PCR}

A tisztított RNS mintákat a Fermentas First Strand cDNA Kit segítségével írtuk cDNS-sé, melyeket későbbi RT-PCR és qPCR vizsgálataink során templátként használtunk fel. A reakcióban a javasolt protokollt kis mértékben módosítottuk a nagyobb hatékonyság elérése érdekében, így $5 \mathrm{x}$ puffer jelenlétében a $3 \mu \mathrm{g}$ RNS-hez $0,5 \mu \mathrm{g}$ oligo(dT) ${ }_{18}, 1 \mathrm{mM}$ dNTP, 20 U RiboLock és 220 U M-MuLV reverz transzkriptáz enzim volt szükséges a protokollban leírt sorrendi és egyéb javaslatok szerint. A tényleges reverz transzkripciós lépést azonban 66 percig végeztük. A cDNS-ek koncentrációit 5x hígítást követően gélelektroforetikusan és spektrofotometriásan is ellenőriztük, az esetleges eltéréseket a gélképek alapján korrigáltuk.

A RT-PCR alapú vizsgálatainkhoz a templát DNS-t a reverz transzkripcióból származó cDNS jelentette, amelyek pontos koncentrációját legfeljebb becsülni tudjuk a cDNS

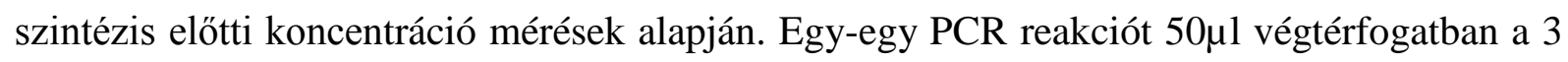
$\mu \mathrm{l}$ cDNS-t 5x GoTaq Flexi puffer 0,6-0,6 $\mu \mathrm{M}$ szekvenciaspecifikus primer, 1,5 mM $\mathrm{MgCl}_{2}$, 0,15 mM dNTP, 1,25 U GoTaq DNS polimeráz jelenlétében végeztünk egy GeneAmp PCR System 9600 (Perkin Elmer, Waltham, USA) segítségével. A felszaporítást 2,5 perces $95{ }^{\circ} \mathrm{C}$ os denaturációs lépéssel kezdtük, majd az alábbi lépések ismétlődtek harminc illetve harmincöt cikluson keresztül: denaturáció 30 másodpercig $95^{\circ} \mathrm{C}$-on, primertapadás 30 másodpercig $55^{\circ} \mathrm{C}$-on és amplifikáció egy percen keresztül $72^{\circ} \mathrm{C}$-on. A ciklusokat követően 4 ${ }^{\circ} \mathrm{C}$-ra hütéssel állítottuk le a reakciót. A PCR során kapott termékeket 1,2\%-os agaróz gélben választottuk el és etídium-bromidos vagy GelGreen-es festéssel tettük láthatóvá, molekulatömeg markerként a lambda fág DNS-ének Pst I enzimmel történő emésztését használtuk, ábráinkon „M” jelöléssel. 


\subsection{Primertervezés}

A PCR reakcióinkhoz a primerek tervezéséhez a Gutierrez et al., 2008, Gasic et al., 2004, Joubés et al., 2008, a Yephremov és Schreiber, 2005, valamint a Samuels et al., 2008ban megjelentetett cikkekben leírt, kutikuláris viasz-bioszintézissel összefüggésbe hozható Arabidopsis thaliana L.(Heynch.) szekvenciák szolgáltatták az alapot.

Belső referenciaként szolgáló gének kiválasztásához számos kutatás eredménye segítségül hívható, azonban ezek nem csupán a kutatott fajok skálájában, de az egyes gének expressziójának egyöntetüségében is eltérést mutatnak (pl. nyár vizsgálatáról lásd Brunner et al., 2004, burgonyáról lásd Nicot et al., 2005; rizs vizsgálatáról lásd Jain et al., 2006). A referenciagének közül végül a Gutierrez és munkatársai által a lúdfü növényt érintő vizsgálatukban találtak alapján választottuk az V. táblázatban felsorolt géneket, melyek szekvenciáit alma EST-kel BLAST program segítségével (Altschul et al., 1997) összehasonlítva kaptuk a tervezéshez szükséges szekvenciákat, kivételt csupán az aktin gén képezett, amelyhez a specifikus primerek szekvenciáját Gasic és munkatársai által 2004-ben közöltek alapján terveztük.

V. táblázat: Az Arabidopsis thaliana esetén használható referenciagének közül kiválasztottak feltételezett alma-beli homológjai

\begin{tabular}{|l|l|l|}
\hline $\begin{array}{l}\text { Gén } \\
\text { megnevezése }\end{array}$ & $\begin{array}{l}\text { Alma } \\
\text { azonosító }\end{array}$ & Lúdfü gén \\
\hline Aktin & GO577606 & At3g53750 \\
\hline EF1 & AJ223969 & At5g60390 \\
\hline EF2 & AJ223969 & At5g60390 \\
\hline EIF4-A & GO557536 & At3g13920 \\
\hline Tubulin & GO555180 & At5g19770 \\
\hline Ubikvitin & DQ438989 & At4g05050 \\
\hline
\end{tabular}

A Jerome Joubés és kutatócsoportja által közölt KCS izoformák közül a közölt lúdfü szekvenciákat alma EST szekvenciákkal hasonlítottuk össze a BLAST program segítségével.-. Az almabeli találatok közül több azonos adatbázisbeli bejegyzésnek bizonyult, így több esetben is egy almabeli KCS homológ egyszerre több lúdfübelinek is megfelel. Ezeket az VI. táblázatban mutatom be. 
VI. Táblázat: Az Arabidopsis thaliana KCS génjeinek feltételezett alma-beli homológjai

\begin{tabular}{|l|l|l|}
\hline $\begin{array}{l}\text { Gén } \\
\text { megnevezése }\end{array}$ & $\begin{array}{l}\text { Alma } \\
\text { azonosító }\end{array}$ & Lúdfü \\
\hline KCS1 & GO562769 & KCS1 (At1g01120), KCS13 (At2g46720) \\
\hline KCS2 & DT001441 & $\begin{array}{l}\text { KCS2 (At1g04220), KCS11 (At2g26640), KCS20 } \\
\text { (At5g43760) }\end{array}$ \\
\hline KCS4/1 & EB127839 & $\begin{array}{l}\text { KCS4 (At1g19440), KCS7 (At1g71160), KCS8 } \\
\text { At2g15090), KCS9 (At2g16280), KCS16 (At4g34250), } \\
\text { KCS17 (At4g34510), KCS18 (At4g34520), KCS21 } \\
\text { (At5g49070) }\end{array}$ \\
\hline KCS4/2 & CN880605 & KCS4 (At1g19440) \\
\hline KCS5 & CO903911 & KCS5 (At1g25450), KCS6 (At1g68530) \\
\hline KCS7/2 & GO504155 & KCS7 (At1g71160) \\
\hline KCS10 & GO514051 & KCS10 (At2g26250), KCS15 (At3g52160) \\
\hline KCS14 & GO522441 & KCS14 (At3g10280) \\
\hline
\end{tabular}

A KCS géneken túl minden további gén esetén a tervezést az időközben hozzáférhetővé vált alma genom-szekvencia adatbázisából történő kikereséssel kezdtük, majd az alma genom projekt és az NCBI adatbázisok közti átjárhatatlanság miatt az így kapott szekvenciához hasonlítottunk BLAST programmal alma EST szekvenciákat az NCBI adatbázisában. A fentebb említett publikációk alapján kiválasztott gének és feltételezett almabeli homológjaiknak elérhetőségét az VII. táblázatban tüntettem fel. 
VII. táblázat: Az Arabidopsis thaliana viasz-bioszintézissel összefüggésbe hozható nem KCStípusú génjeinek feltételezett alma-beli homológjai

\begin{tabular}{|c|c|c|c|c|c|c|c|c|}
\hline \multirow[b]{2}{*}{ 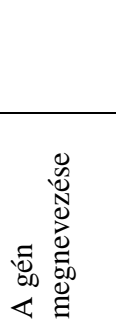 } & \multicolumn{4}{|c|}{ Lúdfü gén - alma genom projekt adatbázis-beli gén összevetés } & \multicolumn{4}{|c|}{$\begin{array}{l}\text { Alma genom projekt adatbázis-beli gén - } \\
\text { alma EST adatbázis összevetés }\end{array}$} \\
\hline & 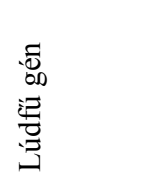 & 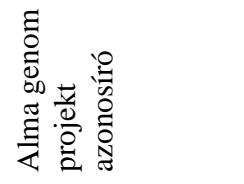 & 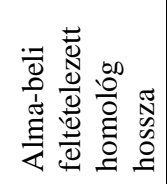 & 高 & 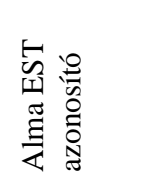 & 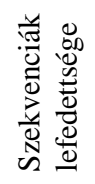 & 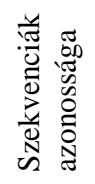 & 幽 \\
\hline CER1 & At1g02205 & MDP0000218683 & $3001 \mathrm{bp}$ & $2 \mathrm{e}-136$ & CN879307 & $57 \%$ & $99 \%$ & 0,0 \\
\hline CER2 & At4g24510 & MDP0000481065 & 1644 bp & 2e-83 & ES789986 & $100 \%$ & $99 \%$ & 0,0 \\
\hline CER4 & At4g33790 & MDP0000298128 & 3091 bp & $7 e-59$ & CN860441 & $49 \%$ & $98 \%$ & $3 e-125$ \\
\hline CER5 & At1g51500 & MDP0000570226 & 597 bp & $1 \mathrm{e}-15$ & GO553197 & $23 \%$ & $77 \%$ & $4 e-04$ \\
\hline CER7 & At3g60500 & MDP0000125831 & 868 bp & $1 e-19$ & GO556217 & $27 \%$ & $92 \%$ & $5 e-69$ \\
\hline CER10 & At3g55360 & MDP0000555908 & 1689 bp & $7 e-73$ & GO497697 & $99 \%$ & $99 \%$ & 0,0 \\
\hline FDH & At2g26250 & MDP0000654110 & 790 bp & $3 e-78$ & DR993902 & $86 \%$ & $99 \%$ & 0,0 \\
\hline HTH & At1g72970 & MDP0000158474 & 5798 bp & 0,0 & GO546350 & $21 \%$ & $100 \%$ & 0,0 \\
\hline KCR1 & At1g67730 & MDP0000462822 & 8775 bp & $7 e-43$ & GO523303 & $54 \%$ & $93 \%$ & $3 e-145$ \\
\hline LACS2 & At1g49430 & MDP0000201853 & 6992 bp & 0,0 & GO503886 & $25 \%$ & $99 \%$ & 0,0 \\
\hline LCR & At2g45970 & MDP0000941955 & $1608 \mathrm{bp}$ & 0,0 & EG631303 & $44 \%$ & $99 \%$ & 0,0 \\
\hline LTPG1 & At1g27950 & MDP0000118904 & 357 bp & $2 \mathrm{e}-24$ & GO524970 & $96 \%$ & $99 \%$ & 0,0 \\
\hline PAS2 & At5g10480 & MDP0000294616 & 749 bp & $3 e-45$ & GO566542 & $100 \%$ & $99 \%$ & $3 e-167$ \\
\hline WAX2 & At5g57800 & MDP0000171443 & 877 bp & $2 e-28$ & DR997009 & $36 \%$ & $93 \%$ & $4 e-53$ \\
\hline WBC11 & At1g17840 & MDP0000193438 & 3674 bp & 2e-162 & CN880528 & $32 \%$ & $99 \%$ & 0,0 \\
\hline WIN1 & At1g15360 & MDP0000430870 & 805 bp & $3 e-50$ & GO498143 & $81 \%$ & $98 \%$ & 0,0 \\
\hline
\end{tabular}

A vizsgálataink során alkalmazott primerek szekvenciáját és az általuk amplifikált termékek tervezett hosszát az VIII. táblázatban foglaltam össze. 


\section{VIII. táblázat A PCR reakcióink során alkalmazott primerek szekvenciái}

\begin{tabular}{|l|l|l|}
\hline ACT & 5' CTACAAAGTCATCGTCCAGACAT & 1000 bp / 1600 bp \\
\hline & 5' TGGGATGACATGGAGAAGATT & \\
\hline EIF4-A & 5' AATGTAATCTGGGCGAAGCGAC & 360 bp \\
\hline & 5' TCTGCAATTCAGCAAAGGGGAA & \\
\hline EF1 & 5' GCTCAAGGCTGAGCGTGAACGT & 398 bp / 600 bp \\
\hline & 5' CAGAAATGGGGACAAAGGGGAT & \\
\hline EF-2 & 5' TGCTTTGCTTGCTTTTACTCTT & 566 bp \\
\hline & 5' CCTCCTTTGCGGGATCATCCTT & \\
\hline TUA5 & 5' GTGCGAAAACACGTAAAAACCA & 390 bp \\
\hline & 5' CCATCAAGACCAAGAGGACAAT & \\
\hline UBQ11 & 5' AGTCCACTCTCCATTTGGTGTT & 370 bp \\
\hline & 5' CCTTCCTTGTCCTGAATCTTAG & \\
\hline KCS 1 & 5' CGTCACTGTCCTCCATGATCGT & 376 bp \\
\hline & 5' CTGCCTTTGTCGTCTTCCCGCT & \\
\hline KCS 2 & 5' TTGTTCAATCCAACCCCATCTC & 356 bp \\
\hline & 5' AAGCACTTATCATCAGCACCCT & \\
\hline KCS 4 & 5' CGCTGAAATCGAACATCACGAC & 348 bp \\
\hline & 5' AAGCACTTATCATCAGCACCCT & \\
\hline KCS 4/2 & 5' ACCCAGGCGGAGCAACCAATGT & 364 bp \\
\hline & 5' AAGCACTTATCATCAGCACCCT & \\
\hline KCS 5 & 5' GAGCATTCCCGCCTCATTCTCA & 468 bp \\
\hline & 5' CATCGCCCTCTCATTGCCTTGG & \\
\hline KCS7/2 & 5' CCCTAAAAACCAACATCACCAC & 464 bp \\
\hline & 5' AGGCACCTCTACAGGAAACTCA & \\
\hline KCS 10a & 5' AGACGAGACCTACATCCCAAAA & 394 bp \\
\hline & 5' GAGCATAGACCTGTCACTACCA & \\
\hline KCS14 & 5' CCACTCGTCCTGCCGTTTACCG & 294 bp \\
\hline & 5' GCCCCTCCCAACCCGACCTTTC & \\
\hline CER1 & 5' CTTGGAAGCTTTAAGCATGTGG & 450 bp \\
\hline & 5' GGAGGAATGGTGATGTGAGTGG & \\
\hline & & \\
\hline &
\end{tabular}

\begin{tabular}{|c|c|c|}
\hline CER2 & 5' CTTCTGCTTTTAATGGTCTTG & 351 bp \\
\hline & 5' GAAATGTATGCGTCTTCGTCT & \\
\hline \multirow[t]{2}{*}{ CER4 } & 5' CTCTCAATACTTTGGGAGC & 205 bp \\
\hline & 5' AGTTTTTCTTGGAGCAGCC & \\
\hline \multirow[t]{2}{*}{ CER5 } & 5' AATGTCCACCACAATGCTA & 323 bp \\
\hline & 5' СТСААТСТСССТССТАААG & \\
\hline \multirow[t]{2}{*}{ CER7 } & 5' AAGAAAAACACAAAGGGGG & 379 bp \\
\hline & 5' CCAAGGCAAGAATAGACTC & \\
\hline \multirow[t]{2}{*}{ CER10 } & 5' GACGATGAAGGTGACCGTAGTTT & 237 bp \\
\hline & 5' TTGTCTGAGTTTCCGCTGATGTA & \\
\hline \multirow[t]{2}{*}{ FDH } & 5' CAGCTCCTCTTCTTTGCCA & 293 bp \\
\hline & 5' TTCACCTTCTCTTTCGCCT & \\
\hline \multirow[t]{2}{*}{ HTH } & 5' CTAAGAATCAAACAACCAA & 459 bp \\
\hline & 5' TGTAGTTTGTGAAATGTTC & \\
\hline \multirow[t]{2}{*}{ KCR1 } & 5' GACCTGCCAAGAATCTCAAAAAG & $281 \mathrm{bp}$ \\
\hline & 5' AATCAAAAGTCCCACATCCAACC & \\
\hline \multirow[t]{2}{*}{ LACS2 } & 5' CTCCСACAAGAAAAAGCAGCACC & 337 bp \\
\hline & 5' CTCTCAGGCAAATCTCTCCACGG & \\
\hline \multirow[t]{2}{*}{ LCR } & 5' GGCTTTACCCTTCTGTTCC & 467 bp \\
\hline & 5’ ATCGACGTCTTCTTTTCCG & \\
\hline \multirow[t]{2}{*}{ LTPG1 } & 5' AAATGATTGCGGTGTTGTT & $261 \mathrm{bp}$ \\
\hline & 5' TCCAGTAGTGGGAGTTGCT & \\
\hline \multirow[t]{2}{*}{ PAS2 } & 5' ATTCCATCTTACACACAAAACCG & 521 bp \\
\hline & 5' ATCTCCAATAACAGCAACACTGC & \\
\hline \multirow[t]{2}{*}{ WAX2 } & 5' CCTTTATATTACTGGGTGC & 413 bp \\
\hline & 5’ TTTGCGTTTAGTGTCTTCC & \\
\hline \multirow[t]{2}{*}{ WIN1 } & 5' ACTGAAGAGAAGGGTGTGG & 285 bp \\
\hline & 5' CATCTCCATCCATGACCTG & \\
\hline \multirow[t]{2}{*}{ WBC11 } & 5' ATCAATGGGCATAAACAAG & 499 bp \\
\hline & 5' CAGAAGCAGGACCAAAATA & \\
\hline
\end{tabular}




\subsection{0. qPCR}

A kvalitatív PCR-t a kiegyenlített koncentrációjú 2011-es almamintákból származó 0,75 $\mu \mathrm{l}$ cDNS templáton végeztük 12,5 $\mu$ l térfogatban, 0,4 $\mu \mathrm{M}$ szekvenciaspecifikus primer, 2x ImmoMix és 20x EvaGreen jelenlétében egy RotorGene 6000 (Corbett/QIAGEN, Venlo, Hollandia) készülék segítségével. Az EvaGreen nem szekvencia-specifikus DNS-festék, mely annak kis árkához kötődve biztosítja a fluoreszcencia növekedését, melyböl következtethetünk a reakció elörehaladására. Az amplifikálást 10 perces $95^{\circ} \mathrm{C}$-on történő denaturálással-hőaktiválással kezdtük, melyet 55 ciklus követett, benne a következő lépésekkel: 5 másodpercig tartó $95^{\circ} \mathrm{C}$-os denaturálás, 20 másodpercig tartó $60^{\circ} \mathrm{C}$-os primertapadás, és egy 20 másodperces $72{ }^{\circ} \mathrm{C}$-on történő amplifikáció. Ezt az olvadáspont analízis követte, mely során $66{ }^{\circ} \mathrm{C}$-ról $99{ }^{\circ} \mathrm{C}$-ig melegítettük a mintáinkat, 0,5 ${ }^{\circ} \mathrm{C}$-onként emelve a hőmérsékletet.

A qPCR vizsgálatok optimalizálásához hígítási sorozatot készítettünk a cDNS-ekből, ezek 2x, 5x, 10x és 30x hígítások voltak, a gyártó által készített ImmoMixben tartalmazott $\mathrm{MgCl}_{2}$ koncentrációt megfelelőnek ítéltük a vizsgálatainkhoz.

A qPCR eredmények kiértékeléséhez a készülékhez alkalmazható Rotor-Gene 6000 Series Software 1.7 programot használtuk, mellyel valós időben történhet meg a PCR-görbék kirajzolása. Az értékeléshez a „Comparative Quantitation Analysis” funckiót választottuk, mely során a második derivált maximumának módszerével megadja a mintához kapcsolódó TOP („Take Off Point”) értéket, amely érték a görbe exponenciális szakaszának kezdetét jelenti, és így e segítségével összehasonlíthatóvá tesz különböző mintákat. A TOP értékek mellett a reakciónk hatékonyságát $\left(E=10^{\frac{-1}{-m}}\right.$, ahol $\mathrm{E}=$ efficiency/hatékonyság, $\mathrm{m}=$ kalibrációs egyenes meredeksége) is megadja, mely számértéke 1 és 2 között van, és 0 és 100\% közötti hatékonyságot fejez ki. A TOP és hatékonyság értékekből a REST C 2009 V2.0.13 program segítségével relatív expressziót határoztam meg a vizsgált génekre, és bár a program elsősorban kezelésszintek közötti, illetve kezelések elötti-utáni állapotok összehasonlítására született, a definíciók alternatív értelmezésével, azaz a kontrollgénjeink értékeit „kontroll” állapotként a célgének értékeit „kezelt” állapotként megadva egymással összehasonlíthatóvá váltak. A program az eredményeket táblázatosan és doboz-bajusz 
diagramként ábrázolja, a számításhoz pedig az alábbi egyenletet alkalmazza: Relatív expresszió $=\frac{\frac{\left(E_{\text {referencigén }}\right)^{C_{T} \text { kezelt }}}{\left(E_{\text {célgén }}\right)^{C_{T} \text { kezelt }}}}{\frac{\left(E_{\text {referencigén }}\right)^{C_{T} \text { kontroll }}}{\left(E_{\text {célgén }}\right)^{C_{T} \text { kontroll }}}}$.

\subsection{Szekvenálás}

A RT-PCR során kapott termékeket a BIOMI Kft-vel szekvenáltattuk, a kapott eredményeket pedig a Chromas Lite Programmal történő javítást követően az eredeti szekvenciával összehasonlítva (BLAST program) ellenőriztük. Ehhez PCR amplifikátumokat készítettünk a korábban leírt PCR protokollt követve, attól függően, hogy mely szövetben láthatunk nagyobb expressziót vagy a 'Prima’ vagy pedig a 'Florina’ fajták terméseinek héját használva templátként, 35 ciklusszámmal. A termékeket 1,2\%-os gélen megfuttattuk, majd gélből visszaizoláltuk az illustra GFX PCR DNA and Gel Band Purification Kit (GE Healthcare, Little Chalfont, Egyesült Királyság) segítségével, a gyártó által javasolt protokollt alkalmazva.

\subsection{Fénymikroszkópos vizsgálatok}

A fénymikroszkópos vizsgálatokhoz a BCE Növénytani Tanszékén Dr. Erős-Honti Zsolt és Solymossy Gábor segítségével készítettünk metszeteket egy Leitz Weitzlar kriosztáton, -25 ${ }^{\circ} \mathrm{C}$-on. Az alma mintákból 1-2 $\mathrm{cm}^{2}$-es szeletet vágtunk ki, és a lehető legkevesebb parenchimális szövettel a mintán rögzítettük a kriosztáton Shandon Cryomatrix (Thermo Scientific, Waltham, USA) közegben. Az így rögzített mintákból $10 \mu \mathrm{m}$ vastagságú metszeteket készítettünk, és azonnal fixáltuk. A fixáláshoz 40\%-os glutáraldehid oldatot használtunk, és egy percen át fixáltuk benne, ezután alapos öblítést követően Szudán IV festékben (0,1 w/v törzsoldat készítése izopropanolban, majd ezt 3:2 arányban hígítva mQ vízzel. 30 perc szobahőmérsékleten tartást követően ALBET 400 szürőpapíron keresztül leszürtük a nem oldódó festékszemcséket) 10 percig állni hagytuk. Ezt követően 50\%-os izopropanolban, majd mQ vízben mostuk. Az így festett metszeteket mQ cseppben tárgylemezre helyeztük, és egy Leitz Labowert (Leica, Wetzlar, Németország) mikroszkópon 10x, illetve 20x nagyításban vizsgáltuk és egy Olympus E-450 (Olympus, Tokió, Japán) fényképezőgéppel fényképeztük, a képeket a Quickphoto camera 2.3 program segítségével dolgoztuk fel. 


\subsection{Konfokális lézer pásztázó mikroszkópos vizsgálatok}

A fluoreszcens képalkotáshoz a fénymikroszkopizáláshoz használt metszési eljárást használtuk. A fixált metszeteket kétféle fluoreszcens festékkel, illetve ezek együttesével festettük, a Buda és munkatársai által javasoltak szerint (Buda et al., 2009). A fixált $10 \mu \mathrm{m}$-es metszeteket auramin $\mathrm{O}$ festőoldatban $(0,01 \mathrm{w} / \mathrm{v} \%$ auramin $\mathrm{O}$ 0,05 M pH=7,2 Tris-HCl-ben) áztattuk sötétben, 15 percen keresztül, majd mQ-vízzel mostuk, és 60\%-os glicerolcseppben tárgylemezre helyeztük, lefedtük és körömlakkal rögzítettük a fedőlemezt. Calcofluor Whitetal történő festésnél a festék oldatában $(0,01$ w/v\%) 5 percig áztattuk a mintákat, majd mQvízzel mostuk, és a fent leírtak szerint rögzítettük. Ha mindkét festékkel festettünk egyidejüleg, akkor a Calcofluor White-ot követően festettünk auramin O-val.

A Calcofluor White MR2 a cellulóztartalmú szöveteket festi, gerjesztése 405 nm-en történt, a kibocsátott jelet 415-448 nm között gyüjtöttük be. Az Auramin O a lipofil vegyületeket festi, 458 nm-en gerjesztettük, emissziója 491-563 tartományban van (Buda et al., 2009). A képalkotáshoz egy Olympus Fluoview FV1000 konfokális lézer pásztázó mikroszkópot használtunk, Dr. Pós Veronika segítségével. A vizsgálatokhoz az FV10-ASW 2.1 szoftvert, a metszetek vizsgálatához 10x-es és 20x-os objektívet, 1-5x-ig terjedő optikai zoomot alkalmaztunk. 


\section{EREDMÉNYEK}

\subsection{A kutikula szerepe a paprika termés vízháztartásában}

\subsection{1. 'Hó’ és ‘Titán’ paprikák vízháztartásának jellemzése}

A 2010-ben zajló vizsgálatainkhoz két olyan paprikafajtát választottunk, melyek megfigyelések alapján eltérő módon reagálnak a posztharveszt körülményekre, és így különbséget mutatnak vízháztartásuk paramétereiben, és ezek a 'Hó’ illetve a ‘Titán’ fajták voltak. Elözetes megfigyeléseink alapján a 'Titán’ paprikák hamarabb vesztették el feszességüket, kevésbé voltak pulton tarthatók, azonban erről irodalmi adatok nem álltak rendelkezésünkre. A kutikula szerepének fejlődéstől függő jelentőségének kimutatására 3 fejlődési stádiumban, kloroformmal leoldott felszínű és intakt termések súlyvesztését mértük. A két ismétlésben végzett méréseink eredményeit összegzés nélkül mutatjuk be az 9-11. illetve az 12-14. ábrákon, melyeken rendre a WLR, az össz WLR, valamint a felületegységre vonatkoztatott vízvesztések értékeit ábrázoltuk kezelt illetve kontroll mintákon, a különböző érettségi állapotokban.

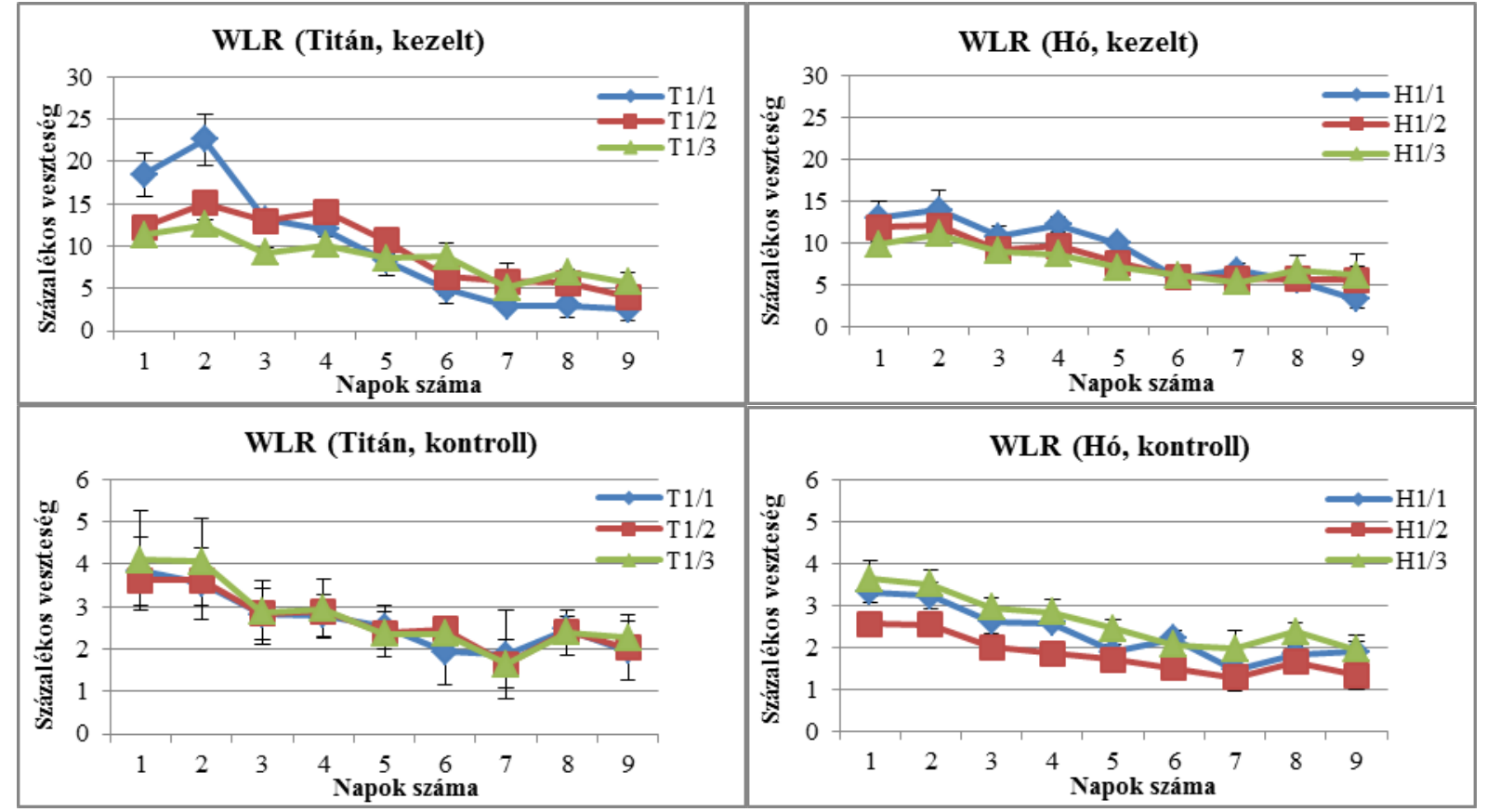

9. ábra: Az első mérés során mért WLR eredmények kloroformmal kezelt és kontroll mintákon, Titán és Hó fajták esetén. Félméretű paprikák: /1, éretlen paprikák: /2, érett paprikák /3 jelöléssel. 
A vizsgálatunk három tényezője (kezelés, érettség, fajta) közül ismétléses varianciaanalízissel megerősítést nyert, hogy mind az oldószeres kezelés, mind a fajta, mind pedig az érettségi állapotok befolyásolják az egyes napi vízvesztések alakulását és a termés tömegének változását, ezek mellett azonban közös hatást találtunk a fajta-érettség, fajtakezelés, kezelés-érettség tényezők, illetve háromszoros együttes hatást a fajta-kezelés-érettség között. Ez alapján elmondhatjuk, hogy nem csupán az egyes tényezők, de ezek kombinációi is befolyással vannak a vízvesztés alakulására, tehát statisztikailag szignifikáns különbség jelentkezett a 'Titán’ és 'Hó’ fajták paprikáinak vízvesztése között, mindhárom érettségi állapotuk és az egyes kezelésszintek között.

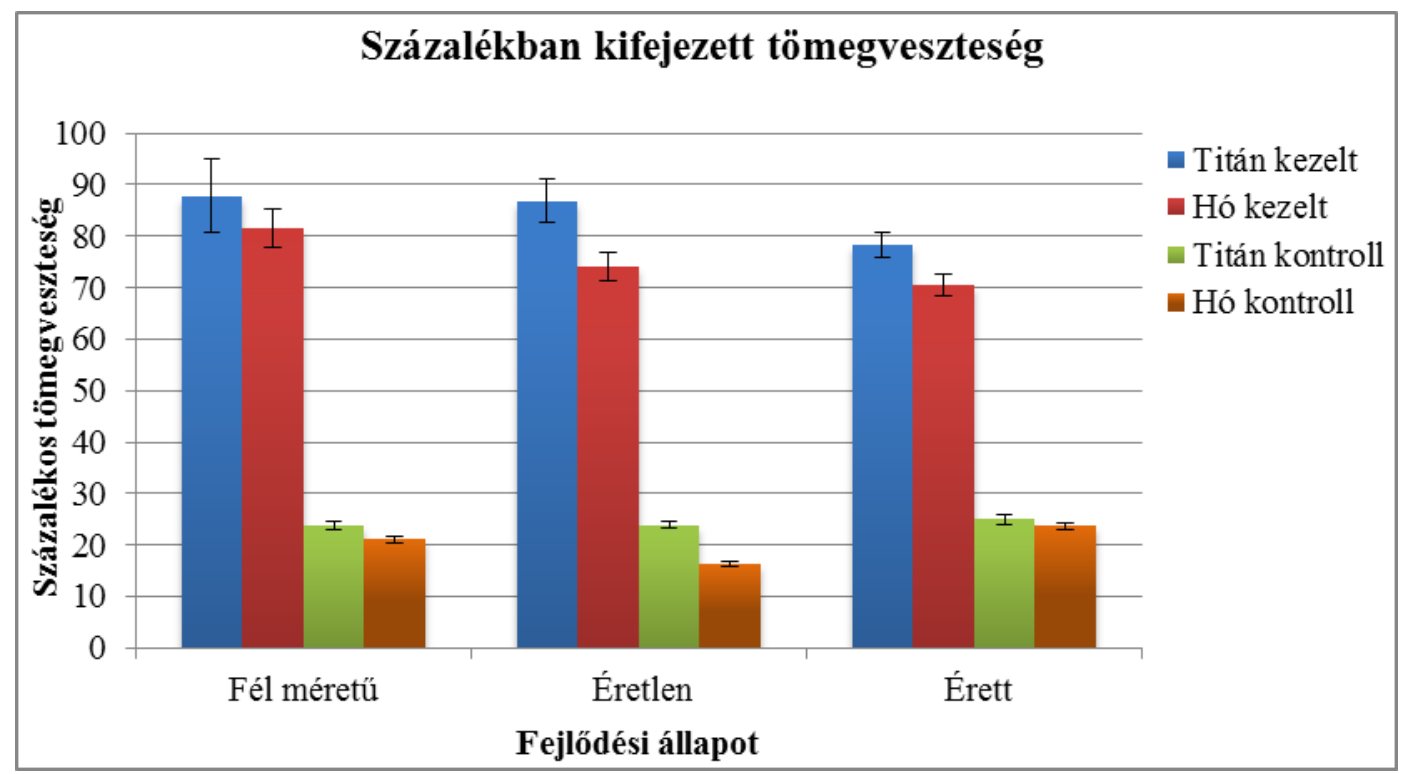

10. ábra: Az első mérés során mért összes WLR eredmények kezelt és kontroll mintákon, Titán és Hó fajták esetén.

Ahogyan az egyes napi értékek ábrázolásakor, az összértékek megjelenítésekor is számottevő különbség látható a kezelt-kontroll csoportok között, egytényezős varianciaanalízissel pedig különbséget találtunk a kezelt csoportnál a fajták illetve az érettségi állapotok között, elkülönül a félméretű és éretlen paprikák csoportja az érett állapottól. A kontroll paprikák esetén azonban csupán a fajták közötti eltérést sikerült bizonyítanunk 95\%os szignifikanciaszinten. 


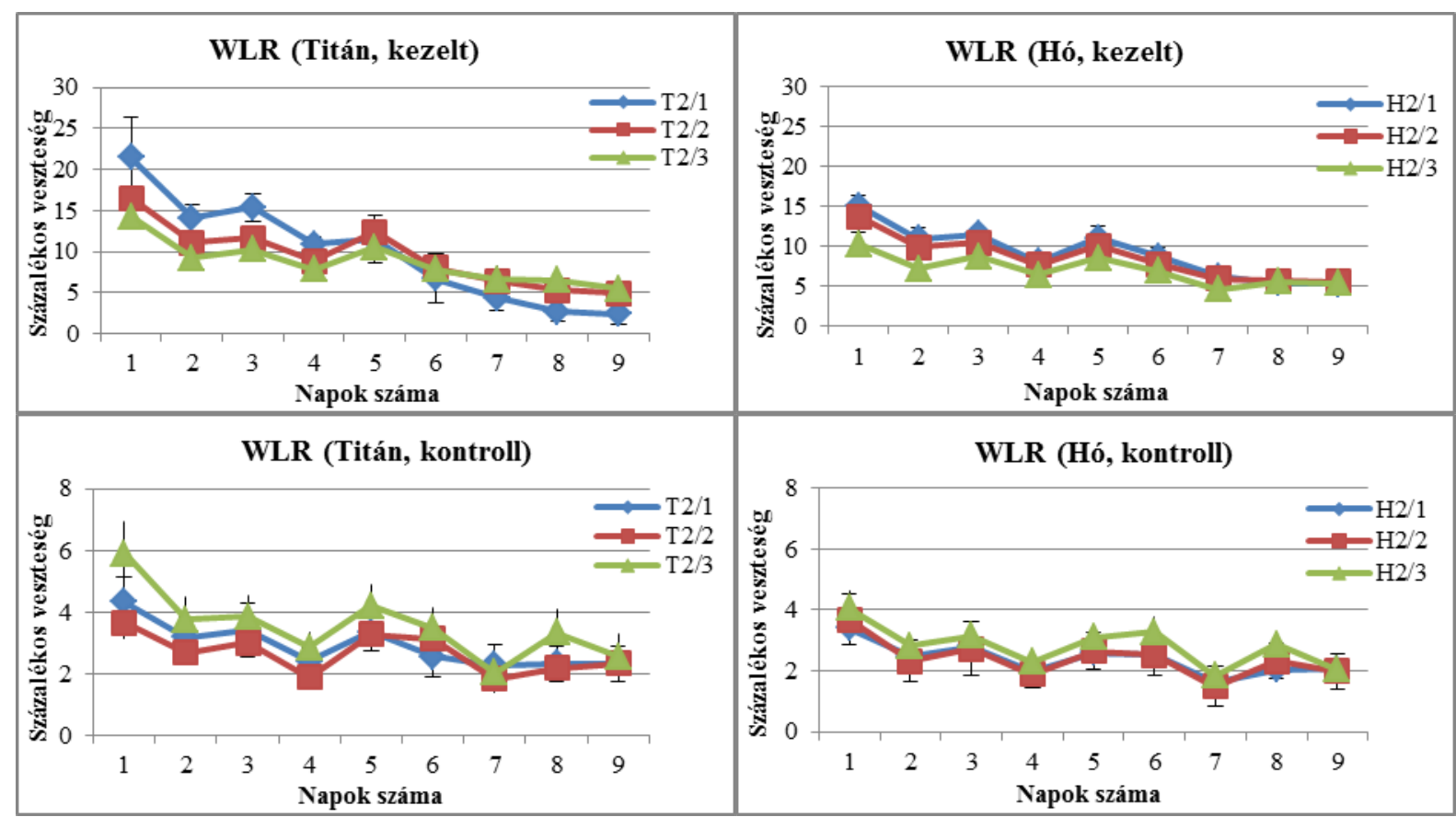

11. ábra: A második mérés során mért WLR eredmények kezelt és kontroll mintákon, Titán és Hó fajták esetén. Félméretü paprikák: /1, éretlen paprikák: /2, érett paprikák /3 jelöléssel.

A második mérés során az egyes napi változások alakulására mindegyik vizsgált tényező és ezek együttesen is hatással voltak (11. ábra).

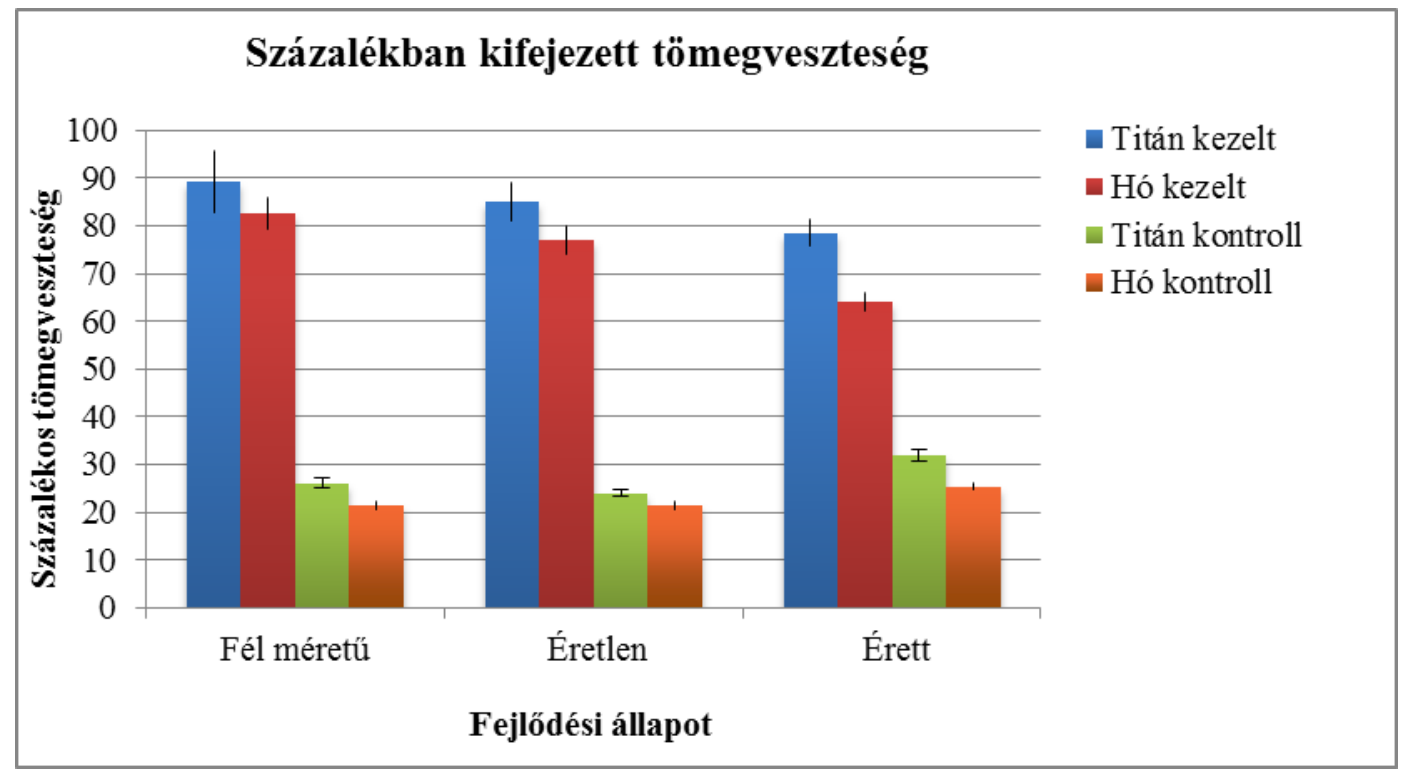

12. ábra: A második mérés során mért összes WLR eredmények kezelt és kontroll mintákon, Titán és Hó fajták esetén. 
Az egytényezős varianciaanalízissel megerősítettük, hogy fajta-érettség együttes hatás kivételével minden tényezőnk befolyásolja az összes vízvesztést, továbbá, hogy a kezelt csoporton belül a három érettségi állapot eredményei 95\%-os szignifikanciaszinten különbözőek, míg a kontroll csoportok esetén csupán a félméretü és éretlen csoport különíthető el az érett csoporttól (12. ábra).

A különböző érettségi állapotokban leoldott viaszok tömegét az egyes paprikák csoportjainak átlagos felületére visszaszámolva kaptuk a felületegységre vonatkoztatott viaszok tömegét (13. ábra), melyen láthatóan növekvő tendencia figyelhető meg mindkét fajta esetén, és míg a 'Titán’ fajta viaszoltsága kiegyensúlyozottabb ütemben alakul ki, addig a 'Hó’ paprikák viaszainak mennyisége a félméretü állapothoz képest az éretlen állapotot követően emelkedik közel kétszeresére.

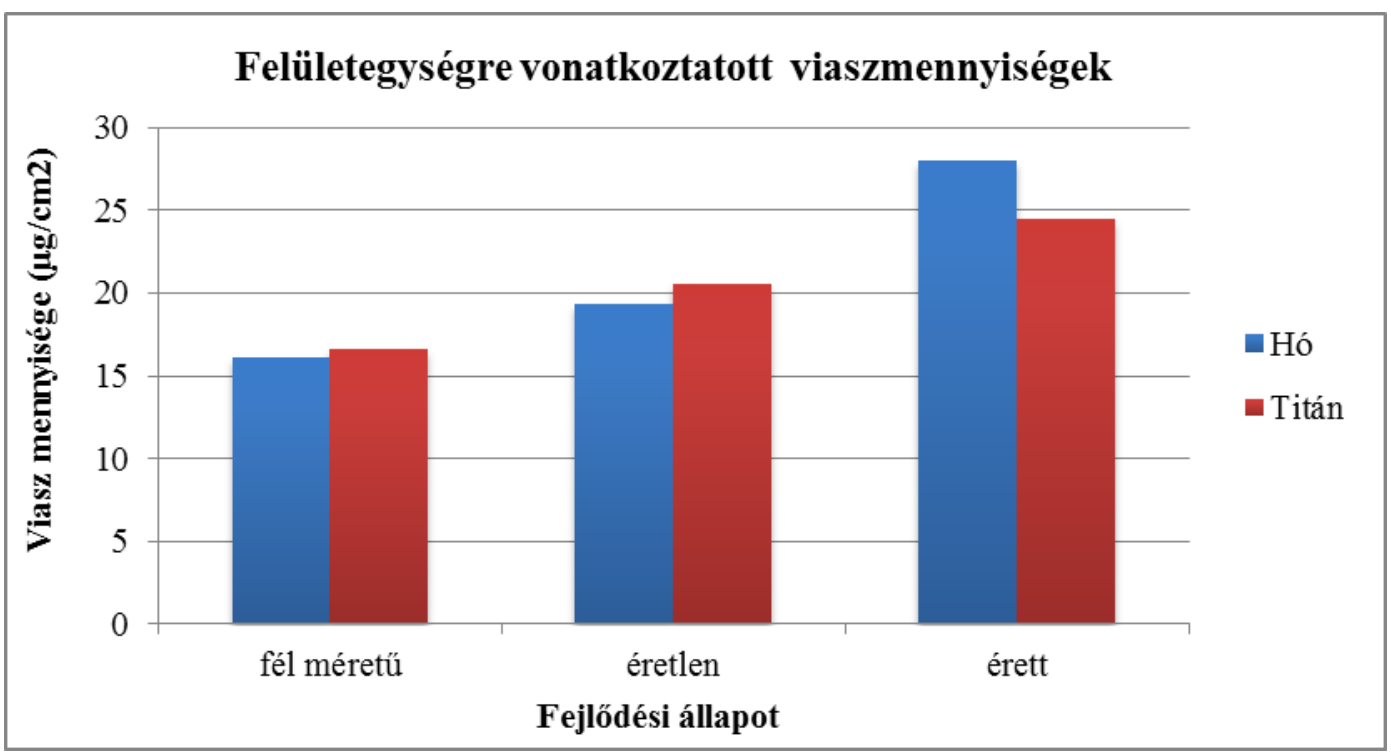

13. ábra: A ‘Hó’ és 'Titán’ paprikák különböző érettségi állapotaiban mért viasztömegek alakulása a fejlődésük során.

\subsection{2. 'Hó’ és 'Kárpia’ paprikák vízháztartásának és kutikuláris jellemzőinek összehasonlítása}

Irodalmi adatok állnak rendelkezésünkre arról, hogy a 'Kárpia’ fajta termései több más fajtával összehasonlítva hosszabban pulton tarthatók, de ennek biológiai háttere már nem ennyire jól feltárt terület. Vizsgálatunkban a WLR, az összes WLR és a felületegységre vonatkoztatott vízvesztés paramétereinek meghatározása mellett szöveti struktúrák vizsgálatát és kutikuláris viasztömeg analízist végeztünk annak érdekében, hogy okot találjunk e 
nagyfokú eltérésre a fajták vízvesztésében. Vizsgálatunkat két ismétlésben végeztük, ezeket egymást követően mutatjuk be a 14-15. ábrákon.

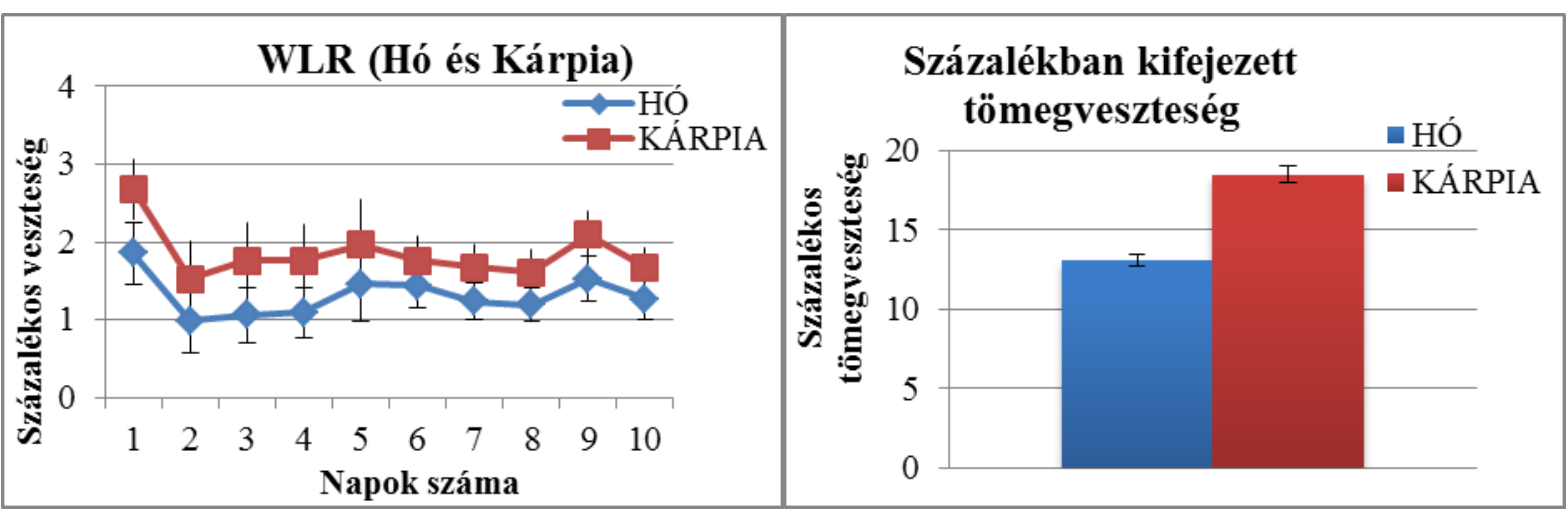

14. ábra: ‘Hó’ és ‘Kárpia’ paprikák WLR (balra) és összegzett WLR (jobbra) első mérése.

Méréseink alapján a 'Kárpia' fajta termései minden nap nagyobb mennyiségben párologtattak, mint a 'Hó’ fajtáéi, ez a különbség az ismétléses varianciaanalízis alapján szignifikáns 95\%-os szignifikanciaszinten. Az egyes napok eredményét összegezve a fajták közti különbség számottevő, egytényezős varianciaanalízissel ellenőrizve szignifikáns.

A második mérés során szintén meghatároztuk a WLR-t és az összegzett WLR-t. A WLR eredmények a két fajta között az első méréshez képest kisebb eltérést mutatnak, azonban a különbség továbbra is szignifikáns (15. ábra).

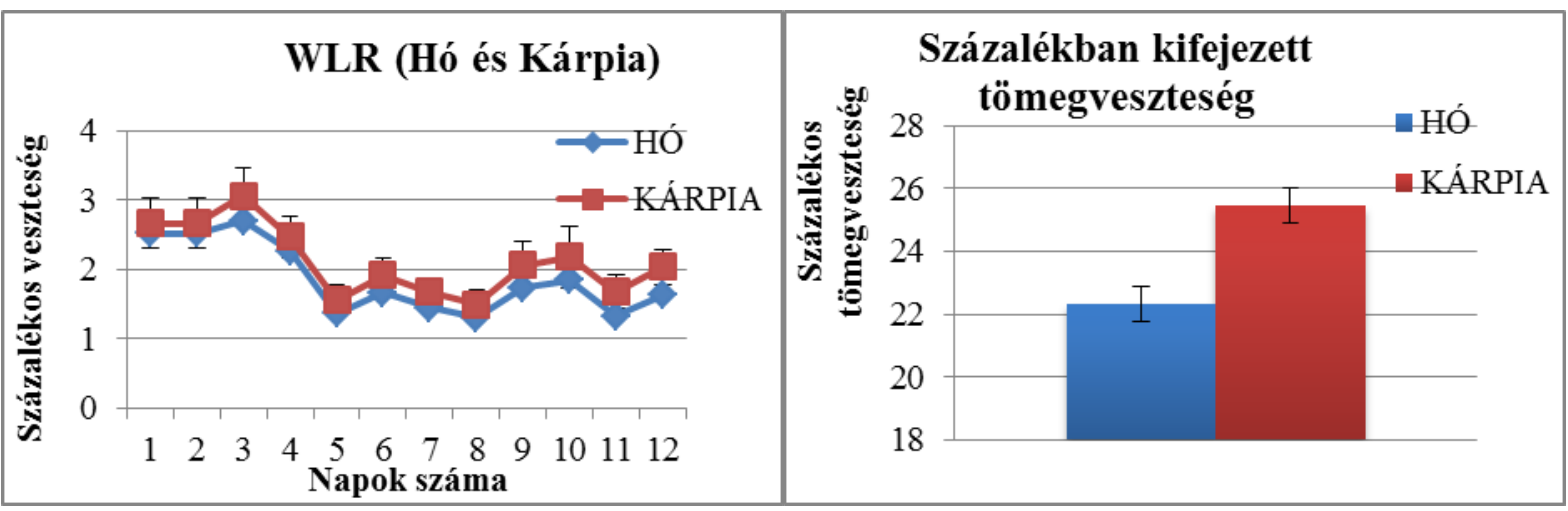

15. ábra: 'Hó' és 'Kárpia' paprikák WLR (balra) és összegzett WLR (jobbra) második mérése.

Ebben az egy esetben azonban annyira sérült az adatok szfericitása, hogy ez a GreenhouseGeisser korrekcióval már nem volt javítható, ezért a probléma kiküszöbölése érdekében BoxCox transzformációt alkalmaztunk, és az így kapott adatsor már kielégítette a paraméteres 
módszer alapfeltételeit. Az összes WLR vizsgálatakor ismét jelentős különbség látszik a két fajta eredményében, amely különbség az egytényezős varianciaanalízis szerint szignifikáns 95\%-os szignifikanciaszinten.

A kutikuláris viaszok leoldását és bepárlását követően meghatároztuk a felületegységre vonatkoztatott viasztömeget, mely alapján a 'Hó' fajta termésein található nagyobb mennyiségü felületi viasz, ez a különbség a fajták között szignifikáns (16. ábra).

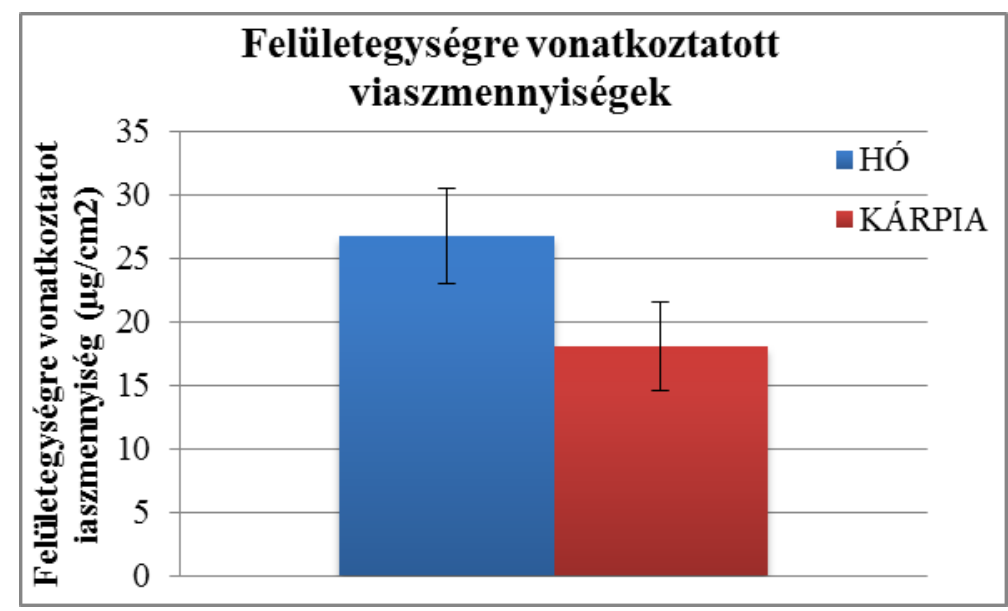

16. ábra: A 'Hó' és 'Kárpia' fajták terméseinek felületegységre vonatkoztatott viaszmennyiségei.

A kutikula esetleges strukturális különbségeinek azonosítására konfokális lézer pásztázó mikroszkópos méréseket végeztünk. A 'Hó' fajta terméseinek fluoreszcens mikroszkópos képei a 17. ábrán láthatók, a mérések során meghatározható kutikula vastagság $11,1 \pm 1,1 \mu \mathrm{m}$ volt. 


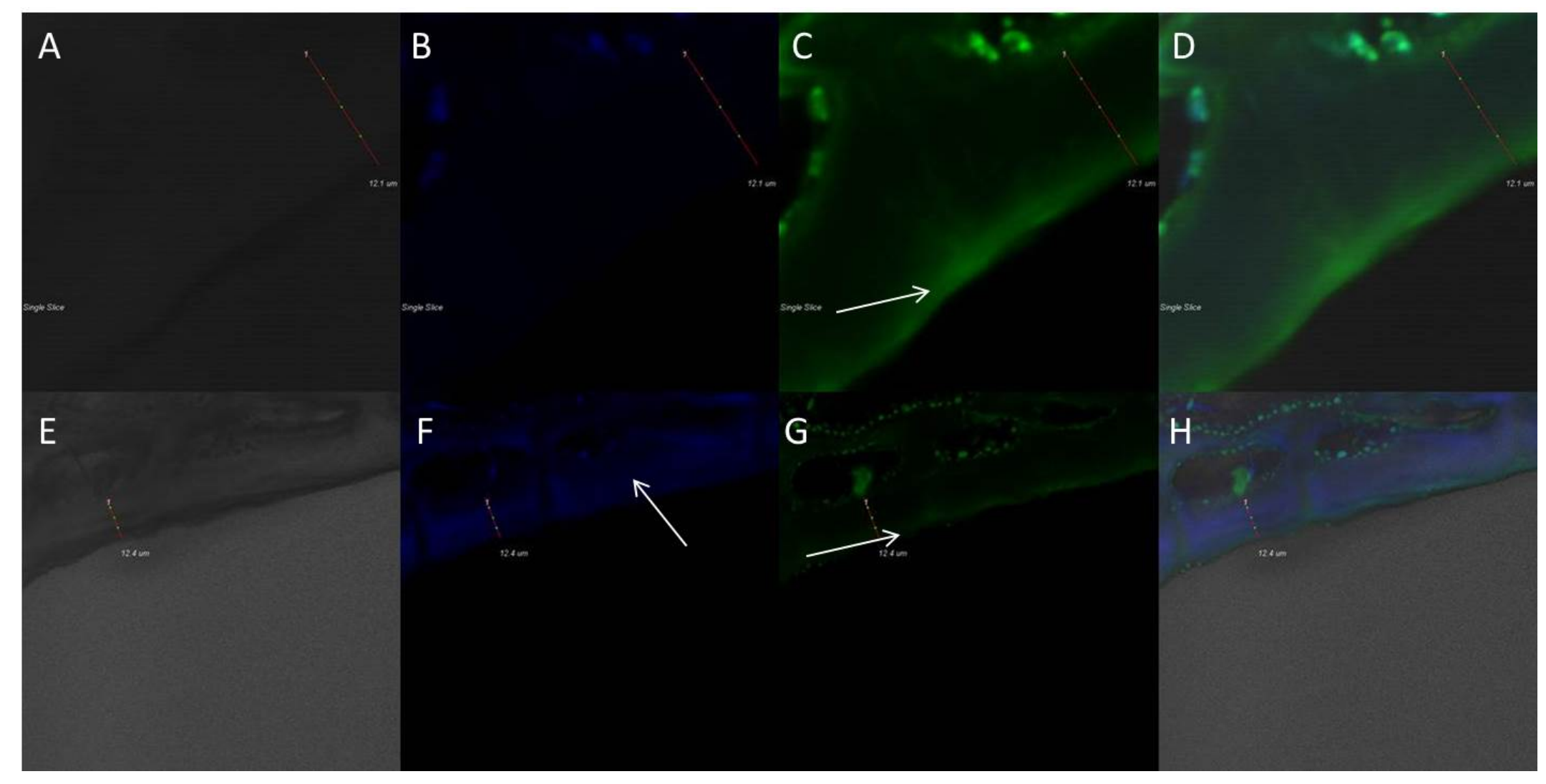

17. ábra: A 'Hó' termés kutikulájának fluoreszcens mikroszkópos képei két reprezentatív mintán; balról jobbra haladva (A-D és E-H): a hagyományos fénymikroszkópos képet (A, E), a Calcofluor White-al (B, F), és az Auramin O-val festett (C, G) képeket majd ettől jobbra mindhármat egymásra rendezve $(\mathrm{D}, \mathrm{H})$ láthatjuk.

A képeken látható, hogy a kutikula külső rétege intenzívebb festődést mutat az Auramin $\mathrm{O}$ festékkel (nyilakkal jelölt terület a $\mathrm{C}$ és $\mathrm{G}$ ábrarészeken), a Calcofluor White festékkel ezzel szemben detektálható, de nem jelentős festődést látunk a periklinális sejtfalak területén az Auramin O jele alatt (nyíllal jelölve az F ábrarészen). 


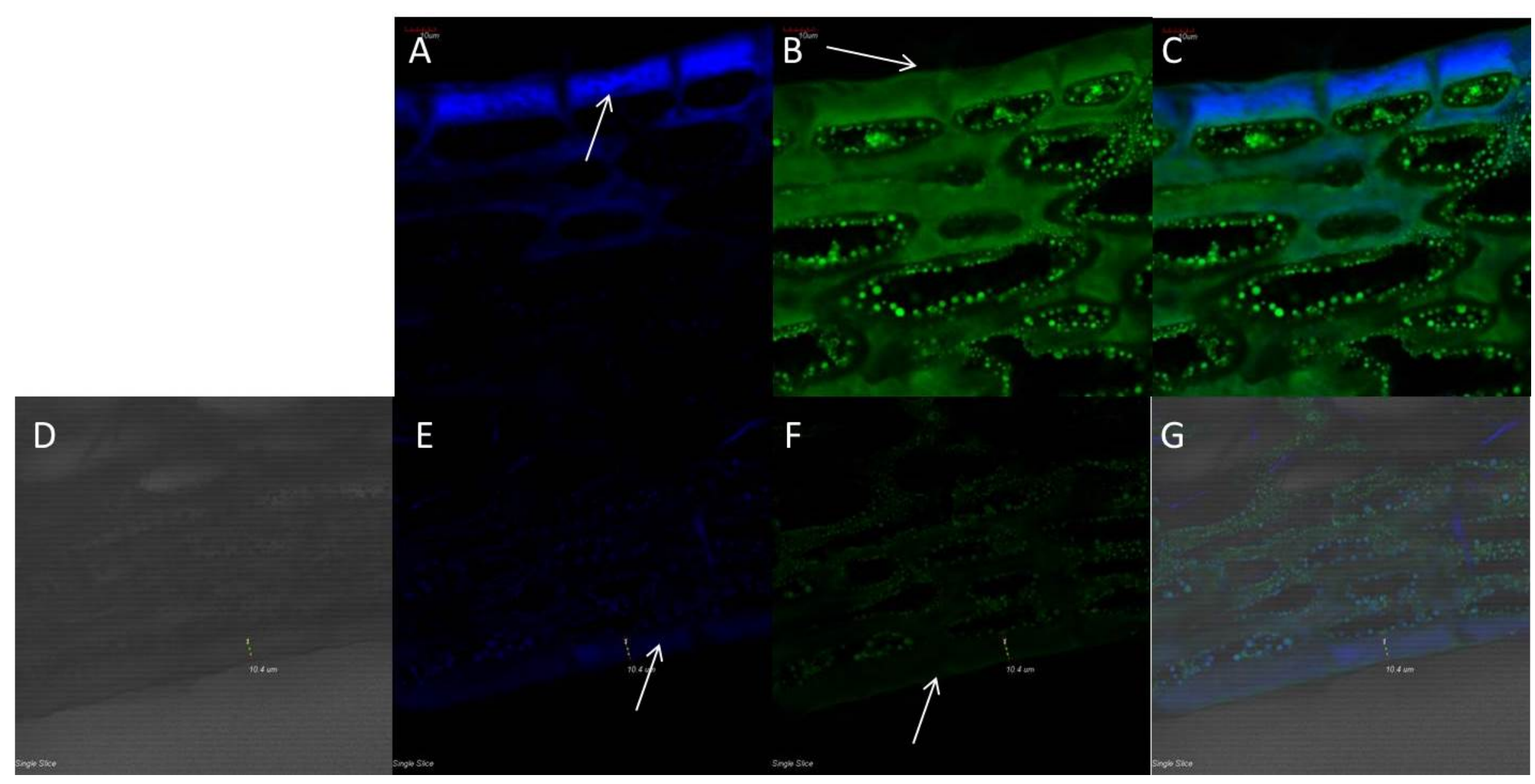

18. ábra: A ‘Kárpia’ termés kutikulájának fluoreszcens mikroszkópos képei két reprezentatív mintán; balról jobbra haladva az első mintán a Calcofluor White, az Auramin $O$, végül e kettő egymásra rendezett képét, míg az alsó panelen balról jobbra haladva a hagyományos fénymikroszkópos képet, a Calcofluor White és az Auramin O festést majd ettől jobbra mindhárom képet egymásra rendezve láthatjuk. 
A ‘Kárpia’ termések szemmel látható eltérést mutatnak a 'Hó’ termésekhez képest (18. ábra), ilyen különbség az Auramin O kevésbé intenzív jele az epikutikuláris régióban illetve a nagyon intenzív Calcofluor White jel a periklinális sejtfalak területén. A kutikula vastagsága 14,1 1 0,7 $\mu \mathrm{m}$ volt, ez a 'Hó’ termések vastagságával összehasonlítva szignifikánsan nagyobb. Megjelennek továbbá a hipodermális sejtsor régióiban zöld jelet kibocsátó gömbszerü testek, melyek feltehetöen a termés vörös színéért felelös plasztiszok és szintén festhetőek a lipofil vegyületekhez kötődő Auramin O festékkel.

\subsection{Viasz-bioszintézissel összefüggő génexpressziós vizsgálatok alma szövetekben}

\subsubsection{Referencia primerek alkalmazhatóságának vizsgálata alma szövetekben}

Génexpressziós vizsgálatainkhoz olyan génekre fókuszáltunk, melyek irodalmi adatok alapján a kutikuláris viaszok bioszintézisével függnek össze. Expressziójuk vizsgálatához

szükség volt minden szövettájban azonos mértékben kifejeződő, belső kontrollként használható, feltételezett housekeeping génekre tervezett primerekre. Előzetes vizsgálatainkhoz a 'Gegesi zöld' fajta termésének héját választottuk, melyből a választott

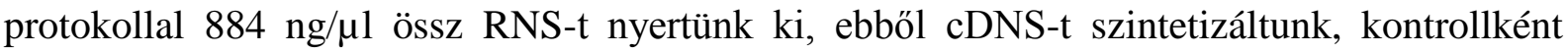
gDNS-t nyertünk ki szintén a héj szövettájból. 40 cikluson végeztünk PCR-t az aktin primerrel, a gélkép a 19. ábrán látható.

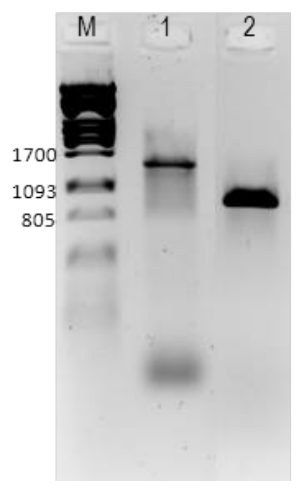

19. ábra: A 'Gegesi zöld' termésének héjából származó gDNS-ből (1) és cDNS-ből amplifikált termékek (2) aktin primerrel, molekulatömeg marker (M) mellett.

Az (1) és (2) sávokban megjelenő kb. 1600 és 1000 bp-os termékek közti nagyfokú méretbeli eltérés, melyeket rendre a genomi DNS-ből és a DN-áz kezelést RNS-ből szintetizált cDNS-ből amplifikáltunk, azzal magyarázható, hogy a genomi szekvencia intront tartalmaz, mely szakasz az RNS érése során kivágódik. E szakasz révén szürhetővé válik az 
RNS minta genomi DNS szennyezése, az aktin primert e vizsgálat alapján alkalmasnak találtuk a genomi DNS kiszürésére.

Belső kontrollként választott primereink közül az ubikvitin, az eukariota iniciációs faktor $4 \alpha$ és a tubulin primerekkel végzett PCR eredménye látható cDNS és gDNS templátokkal az 20. ábrán.

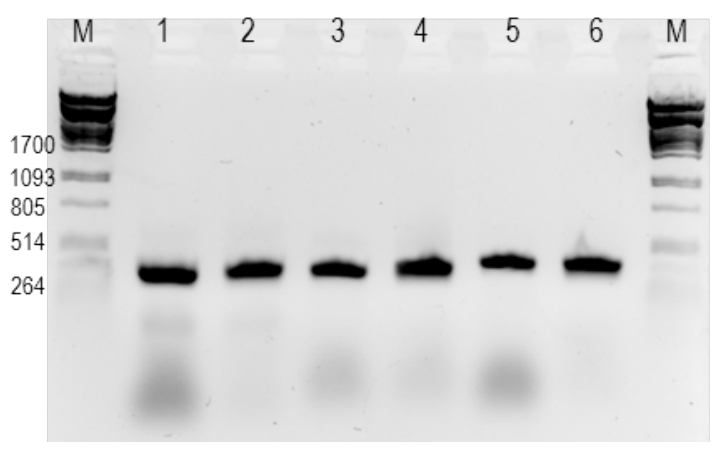

20. ábra: Belső kontrollként használható primerek alkalmazhatóságának vizsgálata. 1-2. sávok: Ubikvitin gDNS és cDNS templáton, 3-4. sávok: EIF4 $\alpha$ gDNS és cDNS templáton, 56. sávok: Tubulin gDNS és cDNS templáton, molekulatömeg marker (M) mellett.

A gélkép alapján elmondható, hogy a fenti primerekkel amplifikált termékek nem különböznek gDNS és cDNS templátokon, gDNS szürésére nem alkalmasak, belső kontrollként történő felhasználásuk több szövetben történő expressziójuk vizsgálata után lehetséges.

További vizsgálatainkhoz a ‘Florina’ levélrügyből származó, DN-áz kezelt RNS-ről átírt cDNS-t alkalmaztuk templátként egy 30 ciklusos PCR-hez, mellyel célunk a módszer későbbi levél szövettájra való alkalmazásának tesztelése volt (21. ábra). 


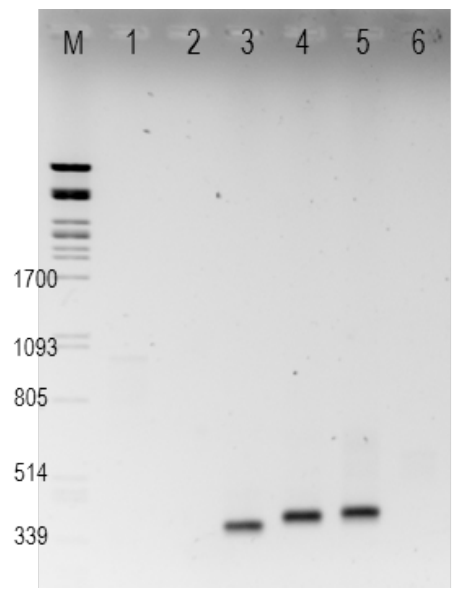

21. ábra: A 'Florina’ levélrügy RNS-böl nyert cDNS-en végzett PCR gélelektroforetikus képe az aktin (1), EIF4 $\alpha$ (2), ubikvitin (3), tubulin (4), EF1 (5), EF2 (6) primerekkel, molekulatömeg marker (M) mellett.

A ciklusszám csökkentésével a reakció felgyorsítása mellett célunk volt a látómezőnk olyan primerekre való leszükítése, melyek alacsony ciklusszám mellett is megbízhatóan amplifikálnak. Feltehetően éppen a ciklusszám csökkentése miatt nem kaptunk terméket a többihez képest hosszabb PCR terméket felszaporító aktin primer esetén, míg szöveti specifitással magyarázzuk az EIF4 $\alpha$ primer sávjában hiányzó jelet. Az ubikvitin és a tubulin primerek továbbra is a várt mérettartományban amplifikáltak. A genomi DNS szürésére szánt, kisebb terméket amplifikáló primerek közül az EF1 primerrel éles, intakt jelet kaptunk, azonban az EF2-vel nem kaptunk terméket, így az EIF4 $\alpha$-hoz és aktinhoz hasonlóan ezt a primert is elhagytuk későbbi vizsgálataink során.

A ‘Florina’ és a 'Prima’ fajták szöveteiből a választott RNS-kivonási módszerrel az 22. ábra szerinti RNS mennyiségeket sikerült kinyernünk a két évjáratban.

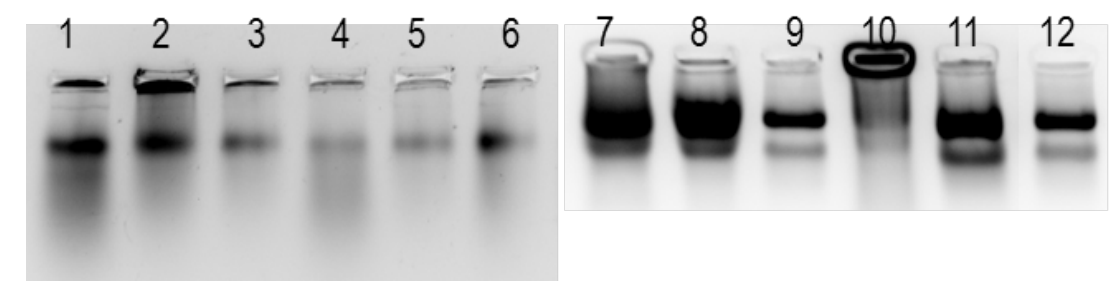

22. ábra: A 2010/2011-es kivonások során nyert RNS-ek gélelektroforéziseinek képei. A bal oldali gélen (1-6. sáv) a 2010-es, a jobb oldalin (7-12. sáv) a 2011-es kivonás eredménye. 'Prima' levél: 1, 10. sávok, 'Prima' héj: 2, 11. sávok, 'Prima’ hús: 3-12. sávok, 'Florina' levél: 4, 7. sávok, ‘Florina’ héj: 5, 8. sávok, ‘Florina’ hús: 6, 9. sávok. 
A minták DN-áz kezelést követően az IX. táblázat szerinti RNS koncentrációkat adták.

IX. táblázat: A ‘Prima’ és ‘Florina’ szövetekből kinyert RNS koncentrációk DN-áz kezelést követően

\begin{tabular}{|l|l|l|l|}
\cline { 3 - 4 } \multicolumn{2}{c|}{} & 2010-es kivonás & 2011-es kivonás \\
\cline { 3 - 4 } \multicolumn{2}{c|}{} & Kivont RNS mennyisége (ng/ $\mu \mathrm{l})$ & Kivont RNS mennyisége $(\mathrm{ng} / \mu \mathrm{l})$ \\
\hline 'Prima' & levél & 148,2 & 998,3 \\
\hline & terméshéj & 60,1 & 994,1 \\
\hline & terméshús & 123,69 & 674,4 \\
\hline 'Florina' & levél & 30,22 & 2465,8 \\
\hline & terméshéj & 98,91 & 1518,7 \\
\hline & terméshús & 121,4 & 559,2 \\
\hline
\end{tabular}

A 2011-es évjáratban megjelenő feljavult kivonási eredményeket a módszer begyakorlásának és nagyobb tapasztalattal történő elvégzésének tudtuk be. A cDNS szintézishez minden

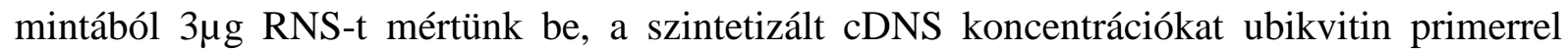
történő kontroll RT-PCR-ek alapján további hígításokkal egyenlítettük ki. Erre feltehetőleg azért volt szükség, mert a cDNS szintézis eltérő hatékonysággal zajlott a különböző eredetü mintákban.

X. táblázat: A 2011-es cDNS minták hígítási paraméterei

\begin{tabular}{|l|l|}
\hline Minta neve & $\begin{array}{l}\text { Hígítás } \\
\text { mértéke }\end{array}$ \\
\hline 'Prima' levél & $16,8 \mathrm{x}$ \\
\hline 'Prima' terméshéj & $38,4 \mathrm{x}$ \\
\hline $\begin{array}{l}\text { 'Prima' } \\
\text { terméshús }\end{array}$ & $46 \mathrm{x}$ \\
\hline $\begin{array}{l}\text { 'Florina' levél } \\
\text { 'Florina' } \\
\text { terméshéj }\end{array}$ & $16 \mathrm{x}$ \\
\hline $\begin{array}{l}\text { 'Florina' } \\
\text { terméshús }\end{array}$ & $26,4 \mathrm{x}$ \\
\hline
\end{tabular}


Az így kapott cDNS mintákkal végeztük a viasz-bioszintézissel összefüggésbe hozható RTPCR és qPCR vizsgálatainkat.

A gDNS kontrollnak kiválasztott EF1 primert a 2010-es mintafeldolgozást követően DN-áz kezelés nélkül teszteltük a 'Prima’ és ‘Florina’ fajták levél, terméshéj és terméshús szövettájából készített cDNS-en.

30 ciklusos PCR-t követően a 23. ábrán látható gélképet kaptuk.

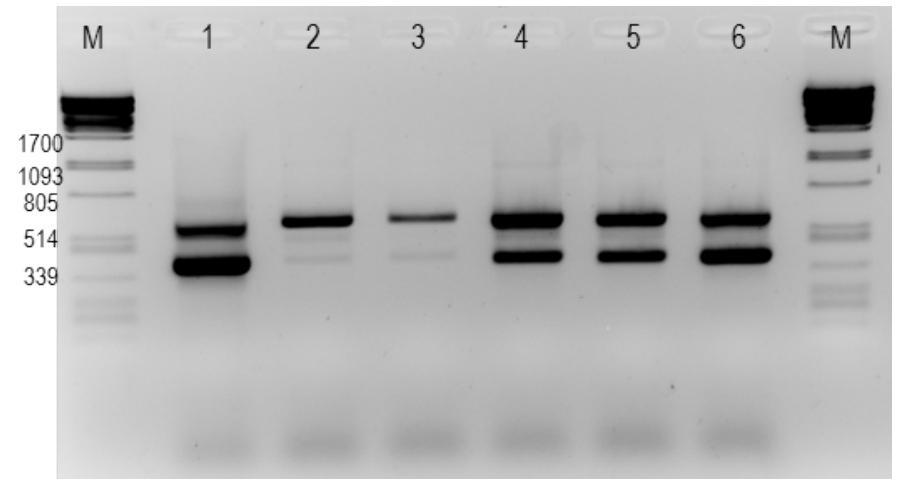

23. ábra: Genomi DNS szennyeződésének kimutatása DN-áz kezelés nélküli RNS-ből készült cDNS-en az EF1 primerpárral. 'Prima’ levél (1. sáv), terméshéj (2), terméshús (3), 'Florina' levél (4), terméshéj (5), terméshús (6), molekulatömeg markerek (M) között.

Genomi DNS szennyeződés jelenléte valószínüsíthető mindegyik szövettájban, ennek eltávolításának érdekében az RNS minták DN-áz kezelése volt indokolt.

A DN-áz kezelt RNS mintákból származó, a fentiek szerint hígított cDNS-eken, ubikvitin primerekkel végzett kontroll PCR a vizsgált szövettájak között hasonló kifejeződési szinteket mutatott (24. ábra).

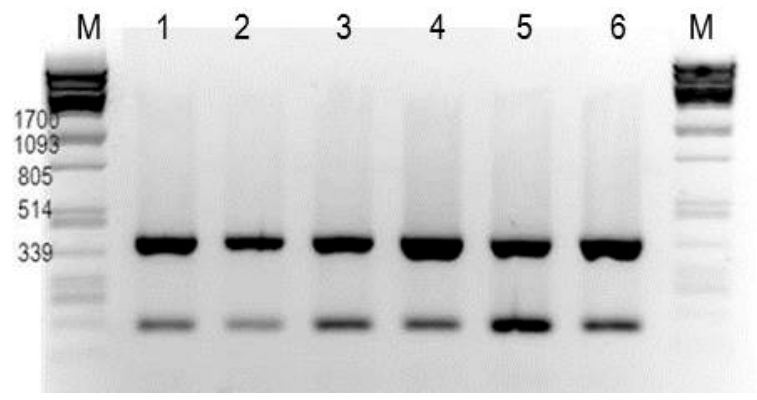

24. ábra: Ubikvitin primerek termékei: M: molekulatömeg marker. 'Prima' levél: 1. sáv, 'Prima’ terméshéj : 2. sáv, 'Prima’ terméshús: 3. sáv, 'Florina’ levél: 4. sáv, 'Florina’ héj: 5. sáv, 'Florina’ hús: 6. sáv. 
Eredményeinket egy másik, gyakran alkalmazott belső kontroll „háztartási” génre, egy, az előkísérletekben azonosított alma tubulingénre tervezett primerekkel is megerősítettük. Az ubikvitin specifikus primerekhez hasonlóan az alkalmazott cDNShígítások mellett ez az RT-PCR is a minták között szinte azonos mennyiségü terméket adott (25. ábra).

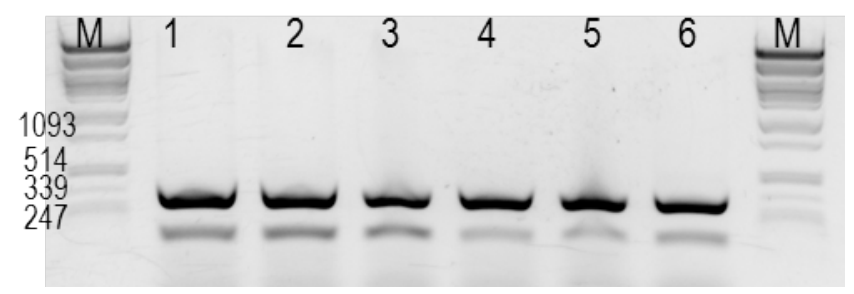

25. ábra: Tubulin primerekkel végzett RT-PCR a cDNS mintákon. A gélelektroforetikus képen a 'Florina' levél: 1. sáv, terméshéj : 2. sáv, terméshús: 3. sáv, 'Prima' levél: 4. sáv, terméshéj : 5. sáv, terméshús: 6. sáv, molekulatömeg markerek (M) között.

\subsubsection{Kutikuláris viaszok bioszintézisével feltételezhetően összefüggő gének expressziójának vizsgálata alma szövetekben}

A kutikuláris viaszok bioszintézise a korábban már bemutatott anyagcsereutakon, a növényi sejteken belül kloroplasztisszal, és endoplazmatikus retikulummal szoros együttműködésben valósul meg. A kloroplasztiszban szintetizálódó C16-C18 zsírsavak bioszintézisével nem foglalkoztunk. Azonban a kloroplasztisz termékeit szállító, átalakító folyamatokkal már igen, melyek közül az első nagyobb, molekuláris szintézisben szerepet játszó csoport a VLCFA bioszintézis KCS géncsaládja volt.

A KCS homológ gének vizsgálatához Arabidopsis thaliana növényen végzett vizsgálat eredményeiből indultunk ki 2010-ben, az itt közölt 21 KCS izoformára nézve homológ alma szekvenciákat kerestük ki az NCBI EST adatbázisában, melyek közül több egymással átfedő szekvenciának bizonyult, így csupán nyolc KCS primert terveztünk az VI. táblázatban bemutatottak szerint. A PCR-t elvégezve a 26. ábrán látható gélelektroforetikus képet kaptuk. 


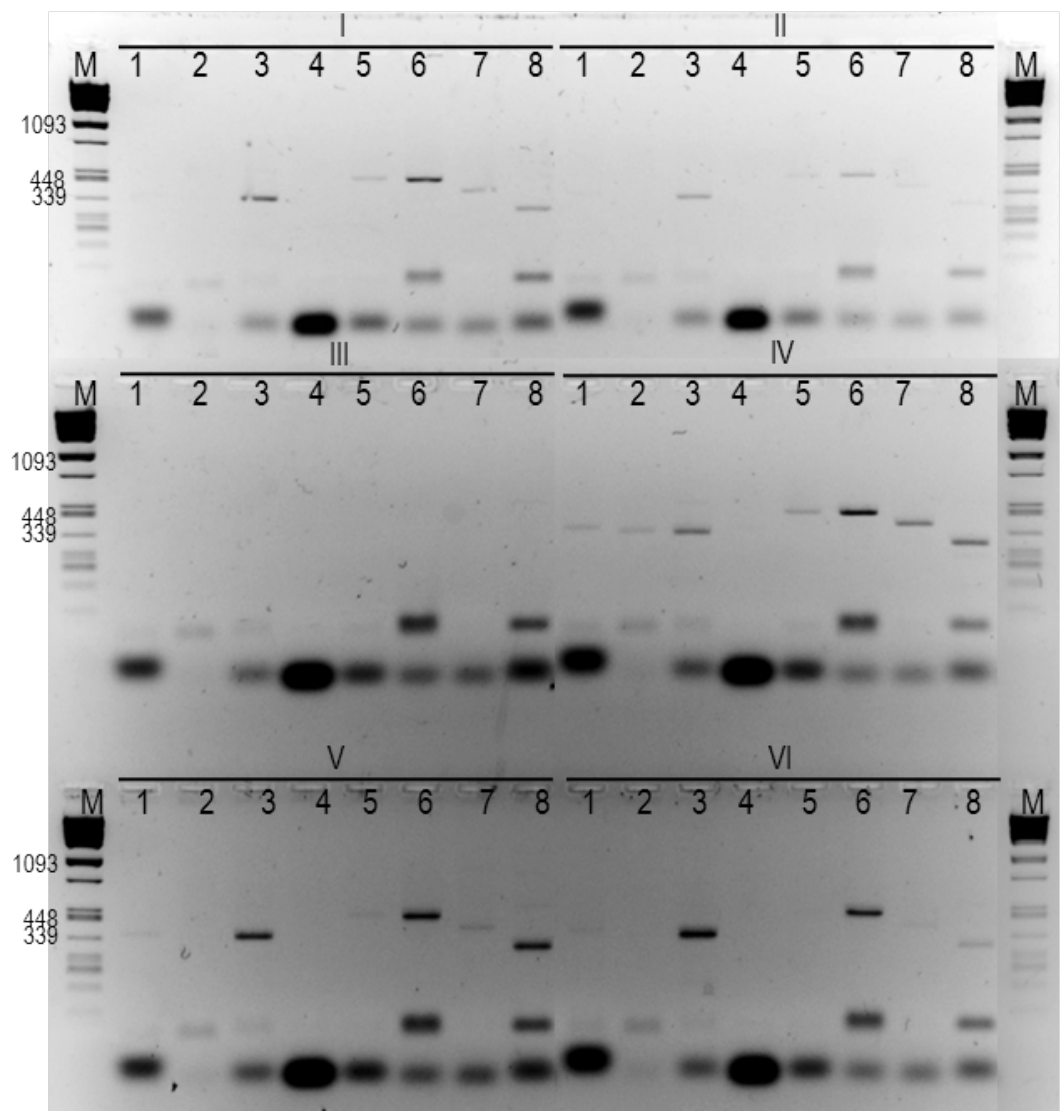

26. ábra: A feltételezhetően KCS funkciójú gének expressziójának vizsgálata alma szövetekben. 'Prima': I-II-III blokkok, 'Florina': IV-VI. blokkok. Levél: I, IV. blokkok, terméshéj : II, V. blokkok, terméshús: III, VI. blokkok. KCS1: 1. sáv, KCS2: 2. sáv, KCS4: 3. sáv, KCS4/2: 4. sáv, KCS5: 5. sáv, KCS7/2: 6. sáv, KCS10: 7. sáv, KCS14: 8. sáv.

A gélkép alapján kijelenthető, hogy az alma-beli KCS homológok expressziója nem csupán szöveti, de fajtaspecifitást is mutat. A vizsgált primerek közül a 'Prima' terméshús szövettájában nem találtunk terméket. Vizsgált primereink közül nem mutatott expressziót a KCS4/2. A 'Prima’ terméshúst leszámítva minden szövettájban expresszálódott a KCS4, a KCS7/2, a KCS10 és a KCS14. Alacsony intenzitású jelet kaptunk 'Florina' fajtában a KCS2 primerrel levél és a terméshéj szövettájában. Terméshús szövettáj kivételével mindenhol, nagyon alacsony expressziós jelet ad a KCS5 primerpárral amplifikált termék. A 'Florina' összes szövettájában megjelenik a KCS1 primerpárral amplifikált termék. Ezek alapján elmondható, hogy a termés viaszoltságának kialakításában a vizsgált gének közül a KCS4, a KCS5, a KCS7/2, a KCS10 illetve a KCS14 homológoknak lehet szerepe, melyek közül gyenge expressziós jel miatt elhagytuk a KCS4, a KCS5 és KCS10 primereket, és csupán a KCS7/2 és KCS14 primerekkel folytattuk vizsgálatainkat a 2011-es mintákon. 
A KCS homológok vizsgálatát követően a viasz-bioszintézis tágabb folyamataiban szerepet játszó gének homológjaira összpontosítottunk, ezekre terveztünk primereket. A lúdfüben leírt vagy feltételezett funkciójú gének alma genom projekt-beli homológjait kerestük ki, amelyeket alma EST-khez hasonlítottunk, és terveztünk rájuk primereket.

A kiválasztott homológok szekvenciáit aminosavszinten összevetettük a lúdfübeli szekvenciákkal, és meghatároztuk a szekvenciák átfedését valamint hasonlóságát. Az eredményeket az VII. táblázatban tüntettük fel, a szekvenciák sematikus illesztése pedig a 27. ábrán látható. 


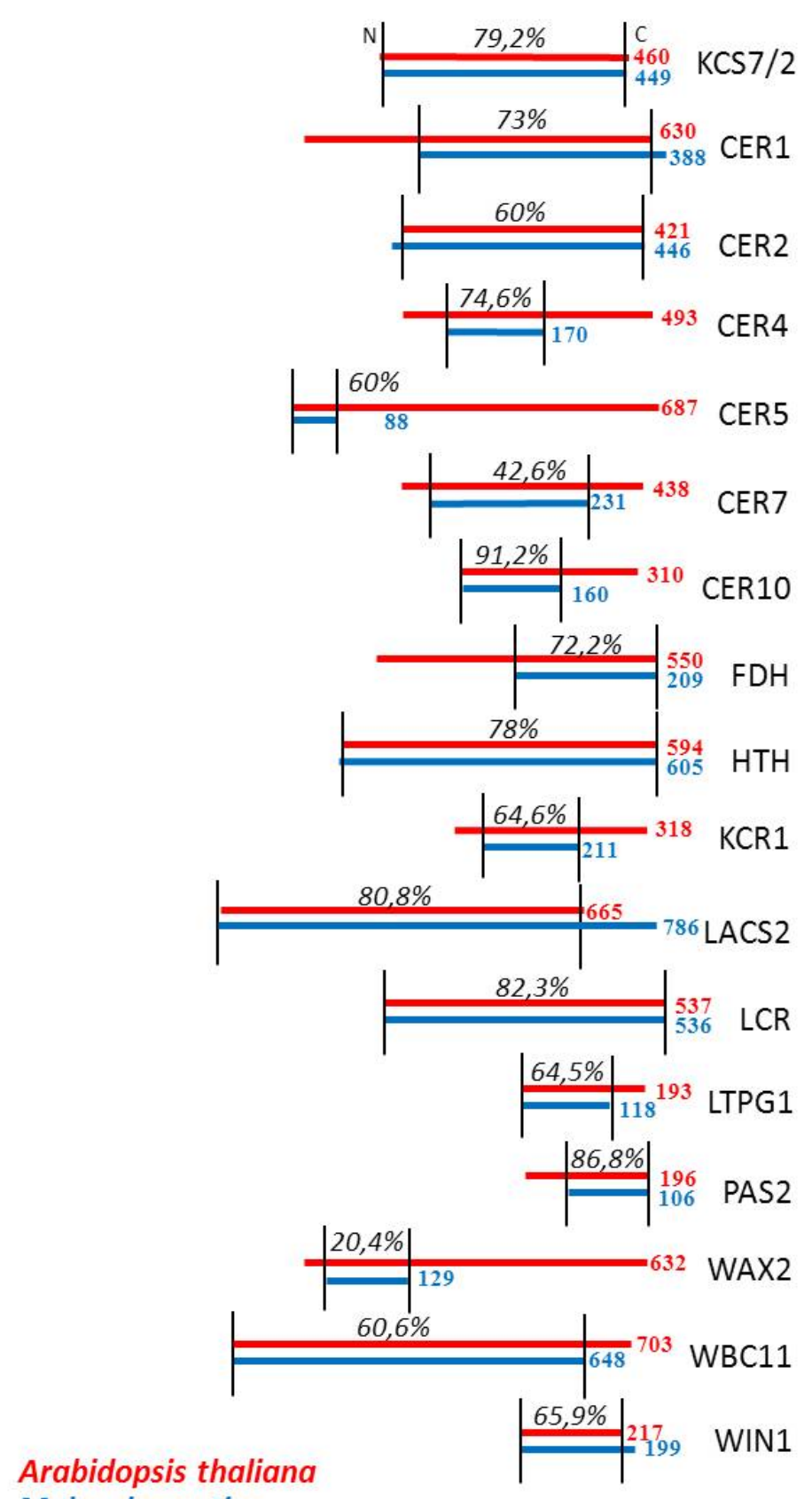

Malus domestica

27. ábra: A kiválasztott lúdfü viasz-bioszintézissel összefüggő fehérjéknek és alma-beli feltételezett homológjaiknak aminosavszintü sematikus illesztése. Az illesztéseken százalékosan megadott hasonlóság látható.

A kiválasztott primerekkel végzett PCR reakciók (30 ciklus) eredményét a 2010-es és 2011-es mintákon a 28. ábrán mutatjuk be. 


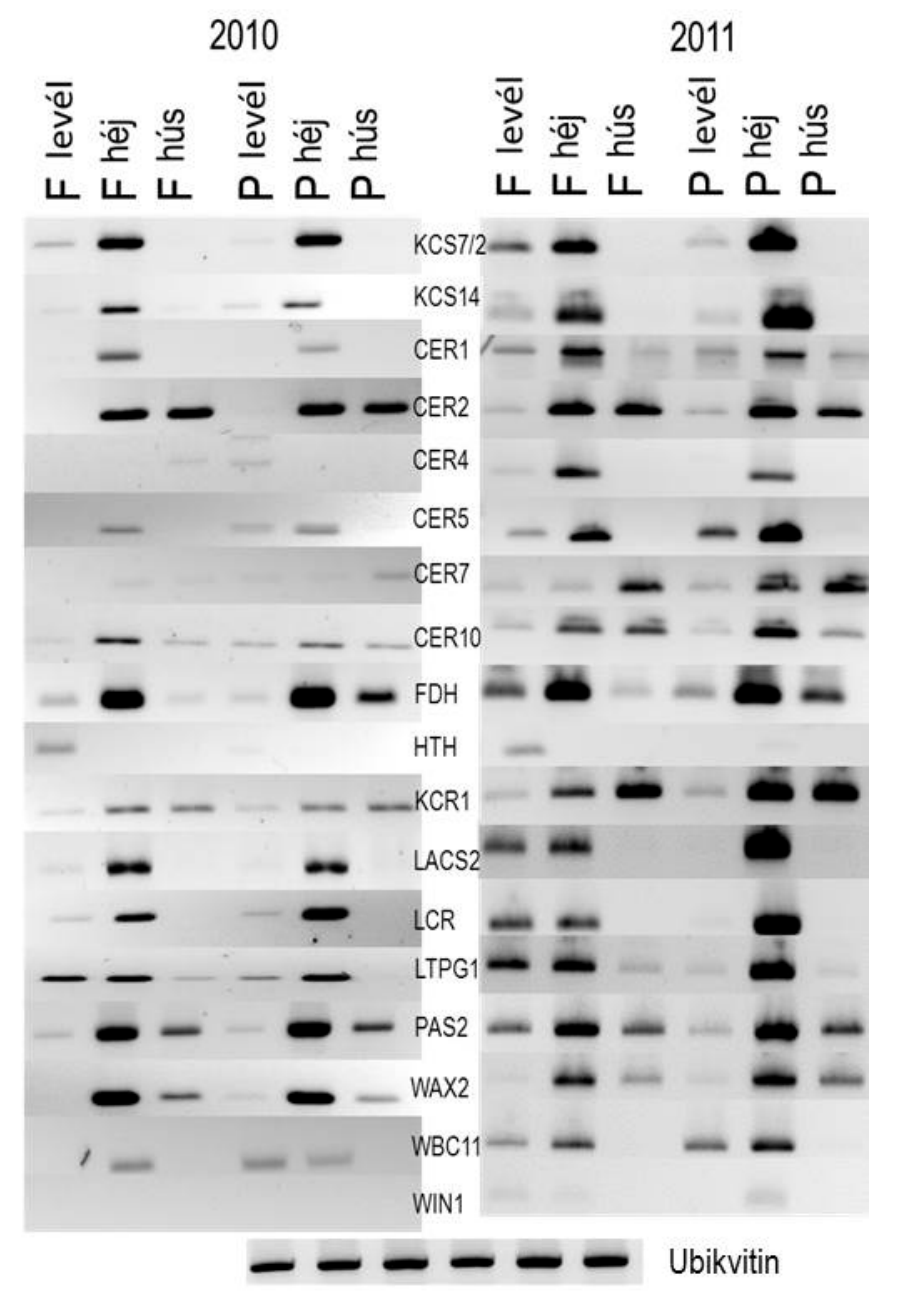

28. ábra: A viasz-bioszintézisben szerepet játszó gének feltételezett alma-beli homológok PCR termékeinek elektroforetikus képe. A bal blokkban a 2010-es, a jobb oldaliban a 2011-es minták termékei, F: 'Florina', P: 'Prima’.

Vizsgálatunk során a terméshéj ában specifikus expressziót kerestünk, mely szerint expressziós jelet vagy csupán a héj szövettájban láthatunk, vagy meggyőzően erősebb jelet mutat e szövettáj a többihez képest. A gélképek alapján ilyet a KCS7/2, a KCS14, a CER1, a CER4 (2011), a CER5, a CER10, a FDH, a LACS2, a LCR, a PAS2, a WAX2 és a WBC11 (2011) feltételezett homológok esetén láthatunk. A CER2 termés-specifikus expressziót mutat, a CER7 a terméshúsában, illetve a 'Prima' esetén héjban is domináns. A HTH feltételezett homológot csak a 'Florina' leveléböl sikerült kimutatnunk, a KCR1 minden szövetben expresszálódik ugyan, de a termésben mutat erősebb jelet. Ettől eltérően az LTPG1 génről bár szintén minden szövetben találunk jelet, erösebb jelet a terméshéj ában, és a ‘Florina’ levelében kaptunk. A WIN1 transzkripciós faktor alma homológjának expresszióját 
csak a 2011 évben sikerült alacsony intenzitással detektálnunk. Az évjárati hatás kiküszöbölésére a két évjáratot együttesen is megvizsgáltuk.

A gélképek alapján kvalitatív és szemikvantitatív tekintetben a LCR homológ expresszálódik a két évjáratban egymással közel megegyező mértékben. Az expressziós mintázat megegyező, de szemikvantitatívan eltérő a KCS7/2, KCS14, FDH, HTH, KCR1, LACS2, LTPG1, PAS2, WAX2 homológok esetén. Harmadik csoportba azokat a géneket soroltuk, melyek expressziós mintázata is eltér a két évjáratban, nem csupán szemikvatitatívan meghatározott mennyiségük. Ezek a CER1, CER2, CER4, CER5, CER7, CER10, WBC11, WIN1 homológok voltak. Az RTPCR megfelelő müködésének, specifitásának ellenőrzésére bizonyos homológok amplifikátumait szekvenáltattuk, melyhez a KCS7/2, KCS14, CER1, CER4, CER5, CER10, KCR1, LACS2, WAX2, WBC11 esetén a 'Florina' héjból, a CER2, FDH, LCR, LTPG1 esetén a ‘Prima’ termésének héjából származó termékeket választottuk.

A géntermékek közül a szekvenáltatást és az eredmények manuális javítását követően az NCBI BLAST 2.2.26+ programja segítségével illesztettük az eredeti szekvenciákhoz, és néhány esetben egy-egy nukleotidos eltérésekkel az eredetivel megegyező szekvenciákat kaptunk, az eredmények összegzését az XI. táblázatban, a részletes illesztéseket az 1. Mellékletben közöljük.

XI. Táblázat: A szekvenáltatást követő szekvenciaillesztések eredményei

\begin{tabular}{|l|l|l|l|}
\hline $\begin{array}{l}\text { Gén } \\
\text { neve }\end{array}$ & $\begin{array}{l}\text { Szekvencia } \\
\text { lefedettsége }\end{array}$ & $\begin{array}{l}\text { Szekvencia } \\
\text { azonossága }\end{array}$ & e-érték \\
\hline KCS7/2 & $65 \%$ & $93 \%$ & 0,0 \\
\hline KCS14 & $40 \%$ & $100 \%$ & $1 \mathrm{e}-127$ \\
\hline CER1 & $43 \%$ & $99 \%$ & $1 \mathrm{e}-153$ \\
\hline CER2 & $19 \%$ & $100 \%$ & $1 \mathrm{e}-167$ \\
\hline CER4 & $45 \%$ & $98 \%$ & $7 \mathrm{e}-59$ \\
\hline CER5 & $52 \%$ & $99 \%$ & $4 \mathrm{e}-97$ \\
\hline CER10 & $20 \%$ & $94 \%$ & $7 \mathrm{e}-59$ \\
\hline FDH & $38 \%$ & $99 \%$ & $4 \mathrm{e}-132$ \\
\hline KCR1 & $42 \%$ & $96 \%$ & $2 \mathrm{e}-120$ \\
\hline LACS2 & $42 \%$ & $99 \%$ & $1 \mathrm{e}-163$ \\
\hline LCR & $35 \%$ & $100 \%$ & 0,0 \\
\hline
\end{tabular}




\begin{tabular}{|l|l|l|l|}
\hline LTPG1 & $71 \%$ & $93 \%$ & $3 e-180$ \\
\hline WAX2 & $52 \%$ & $100 \%$ & $1 e-178$ \\
\hline WBC11 & $60 \%$ & $100 \%$ & 0,0 \\
\hline
\end{tabular}

A vizsgált gének közül a fent bemutatott gélképek alapján a Lacerata homológ mutatott mindkét évjáratban közel megegyező mértékben, terméshéj ra specifikus expressziót, emiatt választottuk ki kvantitatív PCR-es vizsgálatainkhoz. A körülmények optimalizására végzett cDNS-ek 2x, 5x, 10x és 30x hígításainak eredménye a 29. ábrán, látható, balra a tubulin, jobbra pedig az ubikvitin primerekkel végzett PCR, a 2x hígítás eredményéhez viszonyítva; a relatív expresszió kiértékelése pedig a 2. Mellékletben van feltüntetve. A tubulinnal végzett hígítási sorozat eredményeként azt kaptuk, hogy a reakció hatékonysága a 30x hígítású mintában a kezdeti, 2x-es hígítás 67,67\%-os eredményéhez képest 75\%-ra nőtt. Ez az eredmény bár számottevőnek mondható, és a hígítást előnyösnek mondhatjuk a PCR hatékonysága szempontjából, azonban a tubulinnal amplifikált termékek oly mértékben később kezdenek megjelenni a mintákban (29-32. ciklus), hogy későbbi választásunk az ubikvitin primerekre esett, melynél hígítási sorozatban jelentős különbséget a hatékonyságban, amely minden mintában 70\% körüli volt, nem találtunk.
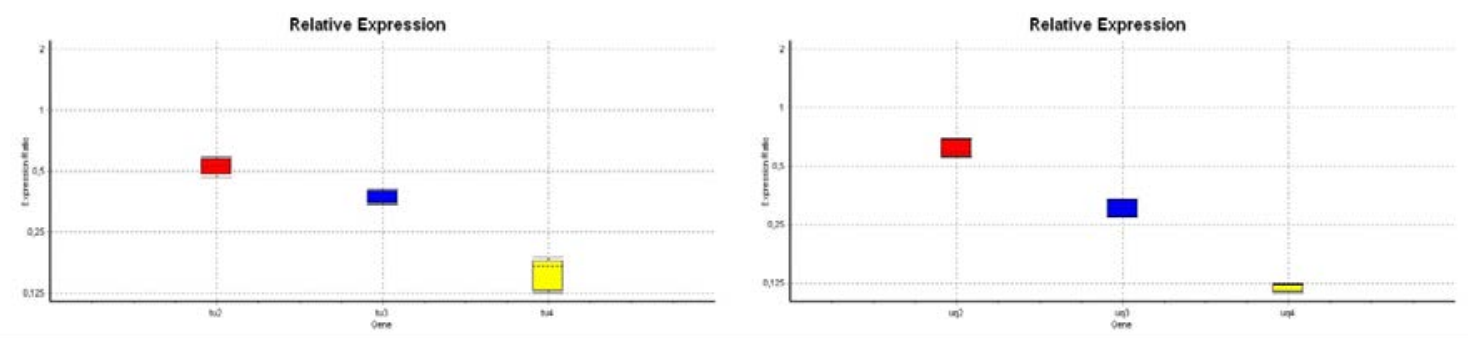

29. ábra: Tubulinnal (balra) és ubikvitinnel amplifikált termékek qPCR-jének kiértékelésének doboz-bajusz ábrázolása. Balról jobbra haladva pirossal az 5x, kékkel a 10x, sárgával a 30x hígítások relatív expressziói láthatóak, a 2x hígítások eredményeit tekintve referenciaként.

A körülmények optimalizálására végzett kísérletek közül a koncentrcáiók kiegyenlítésének ellenőrzésére az ubikvitin primerekkel végzett qPCR eredményét a 34. ábrán mutatom be. Az uq1 (ábrán nem feltüntetett) 'Florina’ levél szövettáj expressziójához viszonyítva láthatók rendre a ‘Florina’ héj és hús, valamint a ‘Prima’ levél, héj és hús szövettájak exressziói. Jól látszik, hogy az ezek közti eltérés nem mondható számottevőnek. 


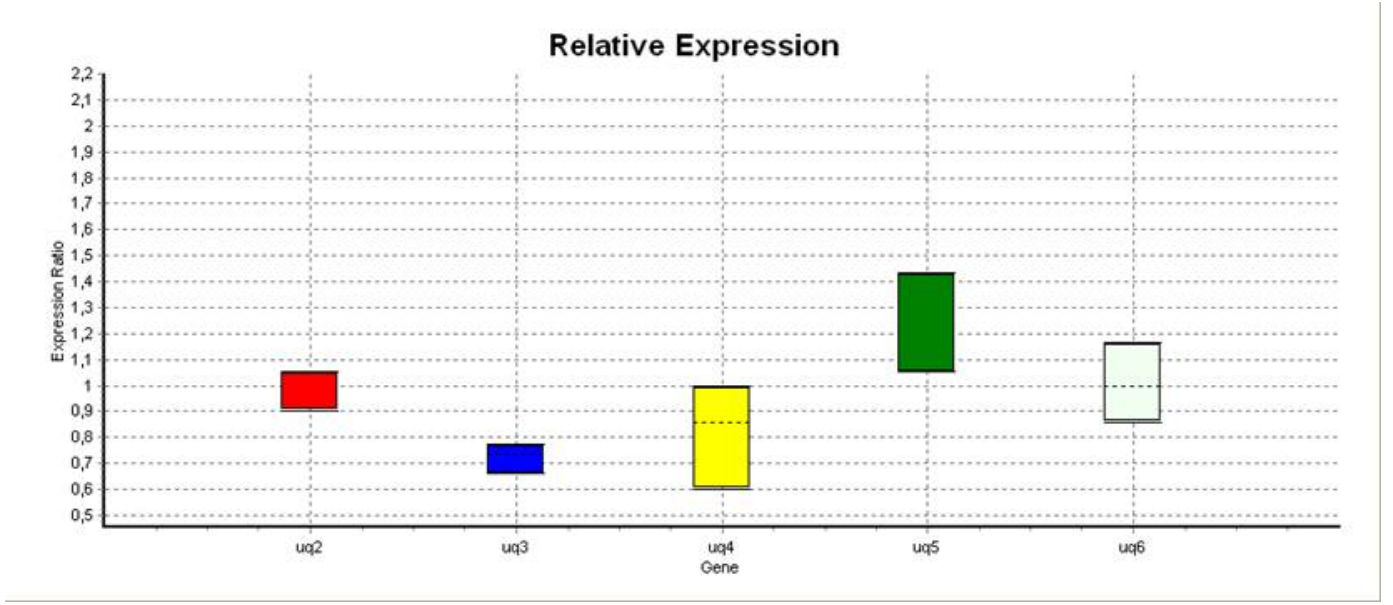

30. ábra: Ubikvitin homológ alma gén expressziója Florina levél referenciára viszonyítva 2011-es szövetekben, balról jobbra haladva ezek: 'Florina' terméshéj és hús, 'Prima' levél, terméshéj és hús.

A Lacerata homológon végzett qPCR során tehát az Ubikvitint választottuk referenciaként, az így kapott eredményeket az 31. ábrán, a kiértékelést pedig az 3. Mellékletben mutatjuk be.

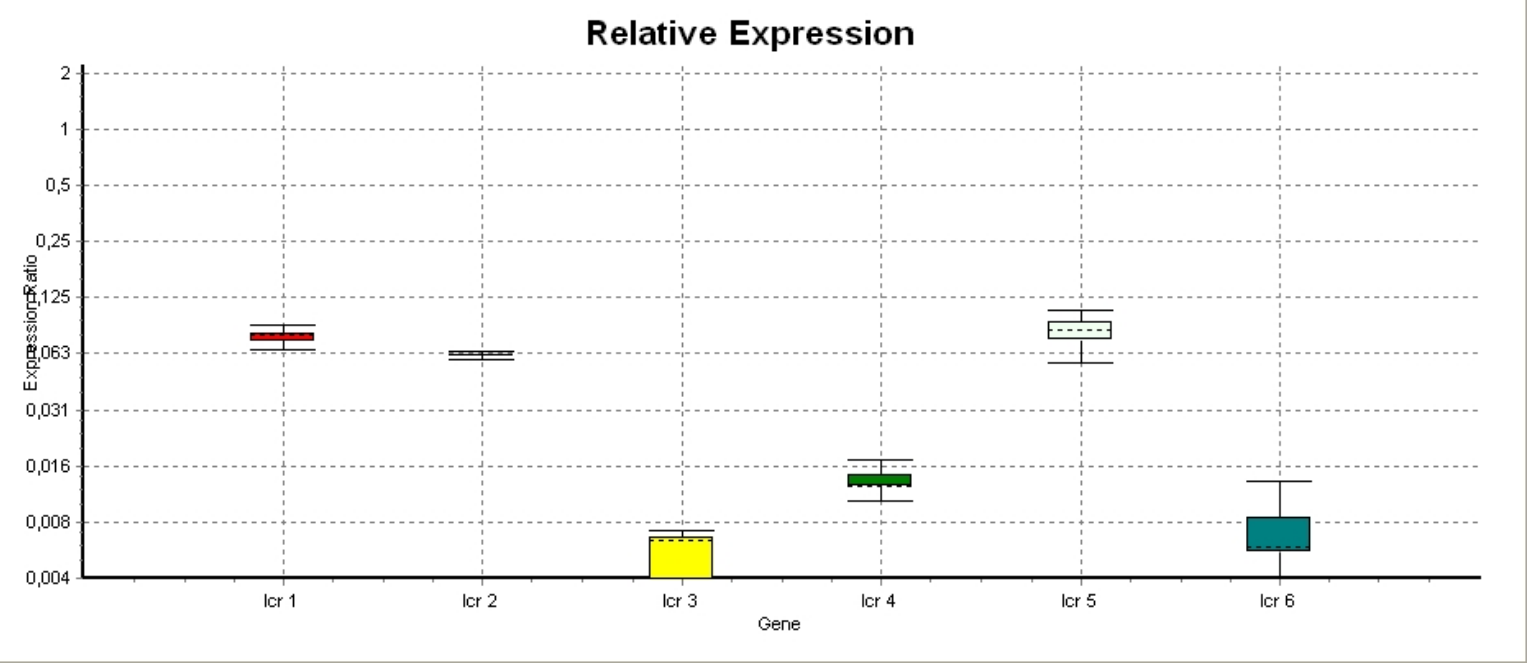

31. ábra: Lacerata homológ alma gén expressziója ubikvitin referenciára viszonyítva 2011-es szövetekben, balról jobbra haladva ezek: 'Florina’ levél, terméshéj és hús, 'Prima’ levél, terméshéj és hús.

Az expresszió mértéke szövetenként eltérő, azonban figyelemre méltónak ítéljük és kiemeljük, hogy a terméshéjak relatív expressziója 0,062 illetve 0,08, mely értékek a legcsekélyebb expressziót mutató ‘Florina’ terméshúshoz képest 15-16-szoros különbségnek tekinthetök. Az egyes szövettájakban megjelenő Lacerata gén expresszióját a legkisebb expressziót mutató ‘Florina’ szövettájjal összevetésben az XII. táblázatban mutatjuk be. 
XII. táblázat: A relatív expresszió mértéke az egyes alma szövettájakban a 'Florina' terméshúsát választva referenciaként

\begin{tabular}{|l|l|}
\hline Szövettáj neve & Expresszió mértéke a ‘Florina’ terméshúshoz képest \\
\hline 'Florina' levél & 15,6 \\
\hline 'Florina' terméshéj & 12,4 \\
\hline 'Prima’ levél & 2,6 \\
\hline 'Prima’ terméshéj & 16 \\
\hline 'Prima’ terméshús & 1,2 \\
\hline
\end{tabular}

\subsection{Az alma termés kutikulájának mikroszkópos vizsgálata}

A növényi kutikula fajonként és egy növényfajon belül gyakran fajtánként is eltérő paramétereket mutat úgy molekuláris összetételében, mint ultrastruktúrájában, kiterjedésében. Számos esetben tártak már fel bizonyítékot arra vonatkozóan, hogy a kutikula szerkezete hatással van akár a párologtatás szabályozására, de kártevők, kórokozók elleni védekezésben is kitüntetett szerepet kaphatnak ezek az eltérések. Az általunk vizsgált gének funkciója jelenleg nem tisztázott az almában, azonban feltehetően viasz-komponensek mennyiségében, illetve a kutikuláris viaszok molekuláris összetételében idézne elő változást ezen gének megváltozott működése. A két vizsgált fajta, a nyári ‘Prima’ és a téli ‘Florina’ esetében ezért megvizsgáltuk azokat a tulajdonságokat, melyekkel összefügghet az eltérő mértékü génexpresszió.

A kutikula vastagságának meghatározását hagyományos fénymikroszkópos illetve konfokális lézer pásztázó mikroszkópos módszerekkel végeztük. A fénymikroszkópos vizsgálatokhoz a Szudán IV festékkel festett és fixált mintákat vizsgáltuk, eltérő nagyítások mellett, néhány reprezentatív fényképet a 32. és a 33. ábrákon mutatunk be. 


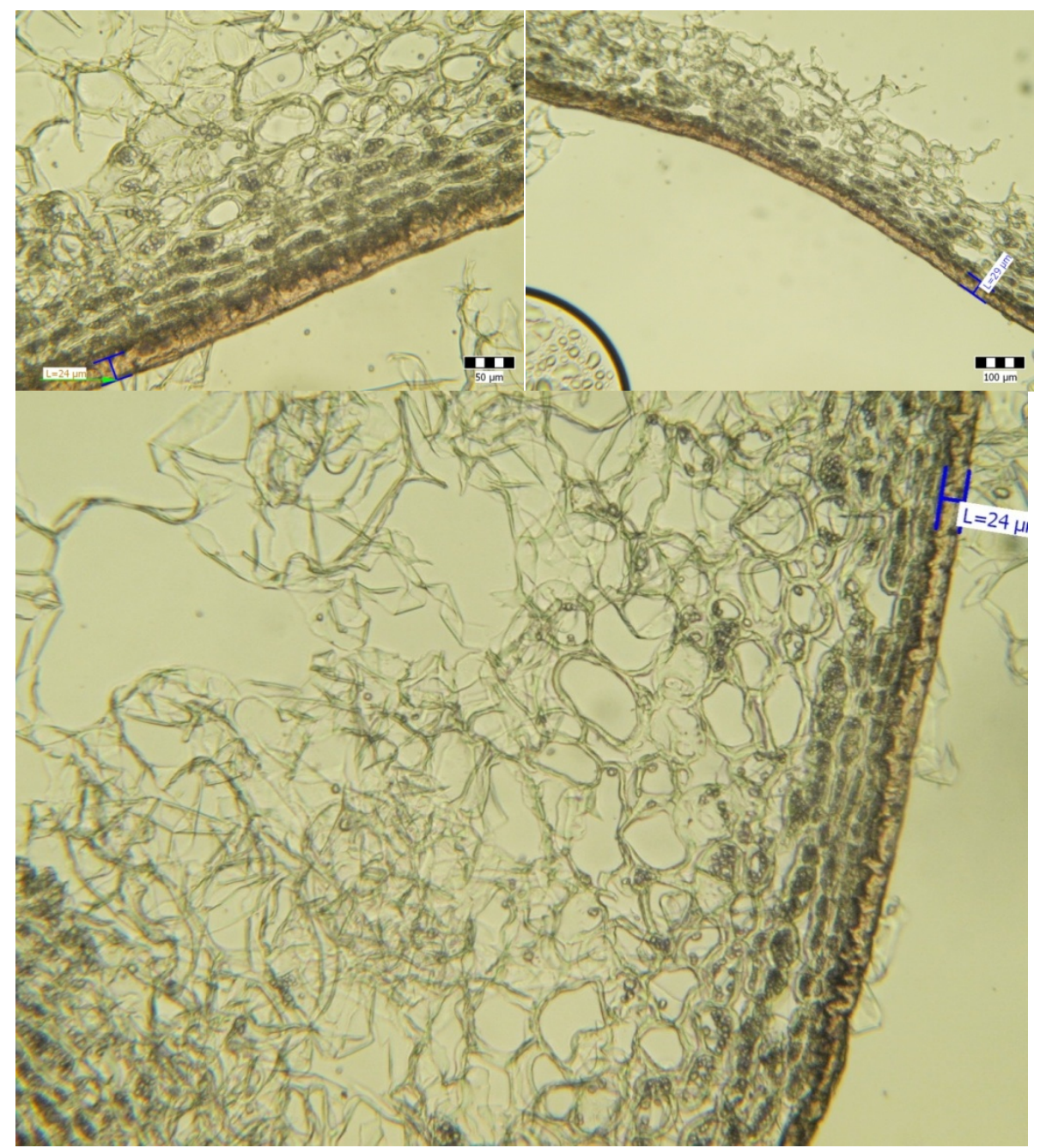

32. ábra: A 'Florina' termés kutikulájának fénymikroszkópos képei Szudán IV festést követően. 


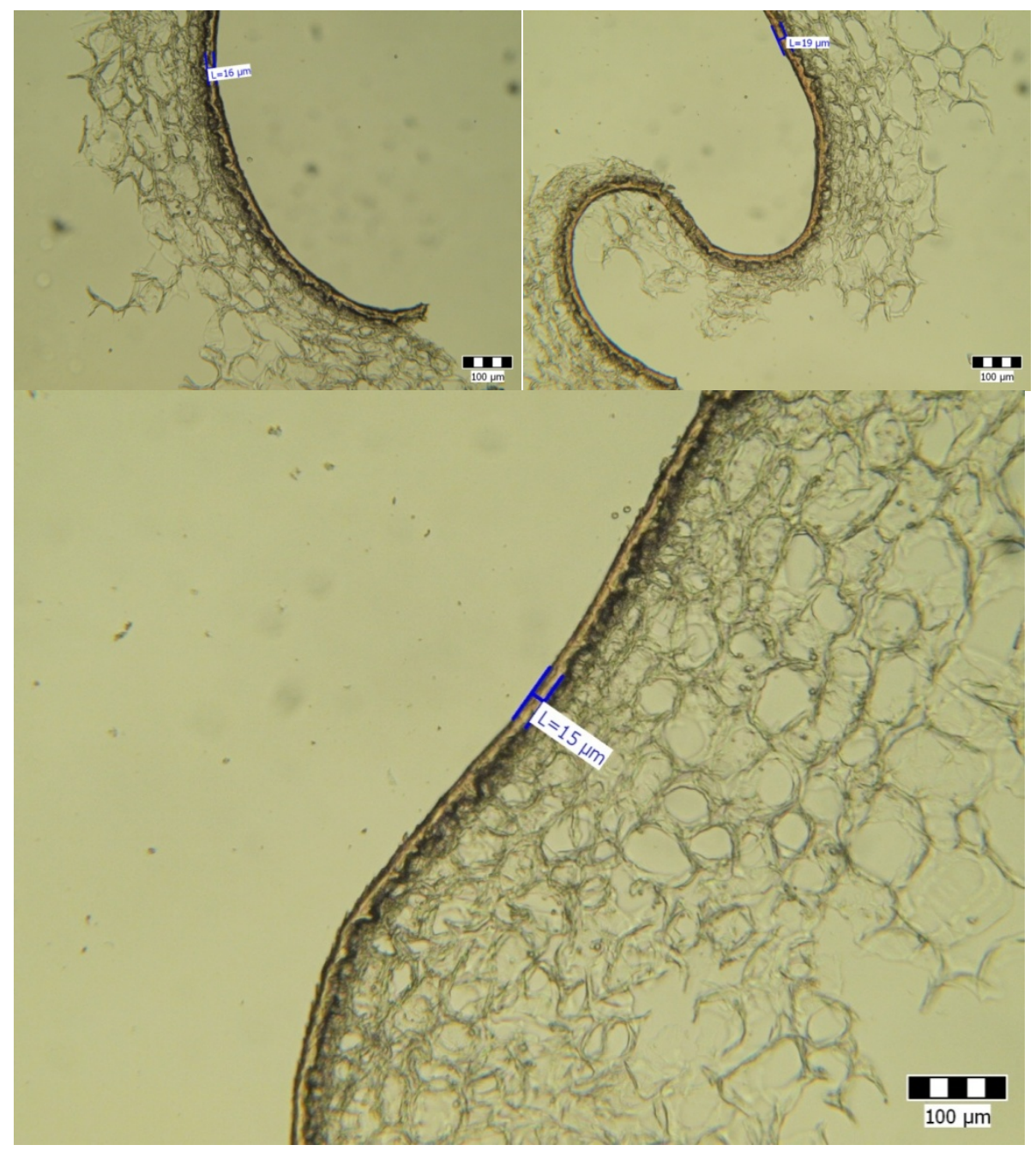

33. ábra: A 'Prima' termés kutikulájának fénymikroszkópos képei Szudán IV festést követően.

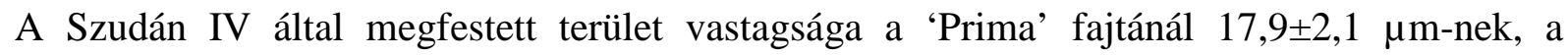

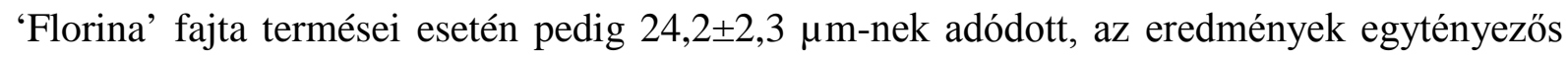
varianciaanalízist követően szignifikánsan különbözőnek mondhatók.

A szövetminták fluoreszcens festését követően konfokális lézer pásztázó mikroszkópos felvételeket is készítettünk annak érdekében, hogy a kutikuláris viaszréteg vastagságát ténylegesen meghatározzuk, ez a detektálási mód ugyanis jelentősen érzékenyebb az apoláris komponensű viaszokra, mint a Szudán IV festés. A Calcofluor White-tal és Auramine O-val együttesen festett, majd fixált minták képei közül néhány reprezentatívat a 34. illetve a 35. ábrákon mutatunk be. A képeket az FV10-ASW 2.1 szoftver segítségével készítettük, a detektált három csatornán (normál fény, kék csatorna, zöld csatorna) készített felvételeket külön-külön, illetve egymásra rendezve mutatjuk be. 


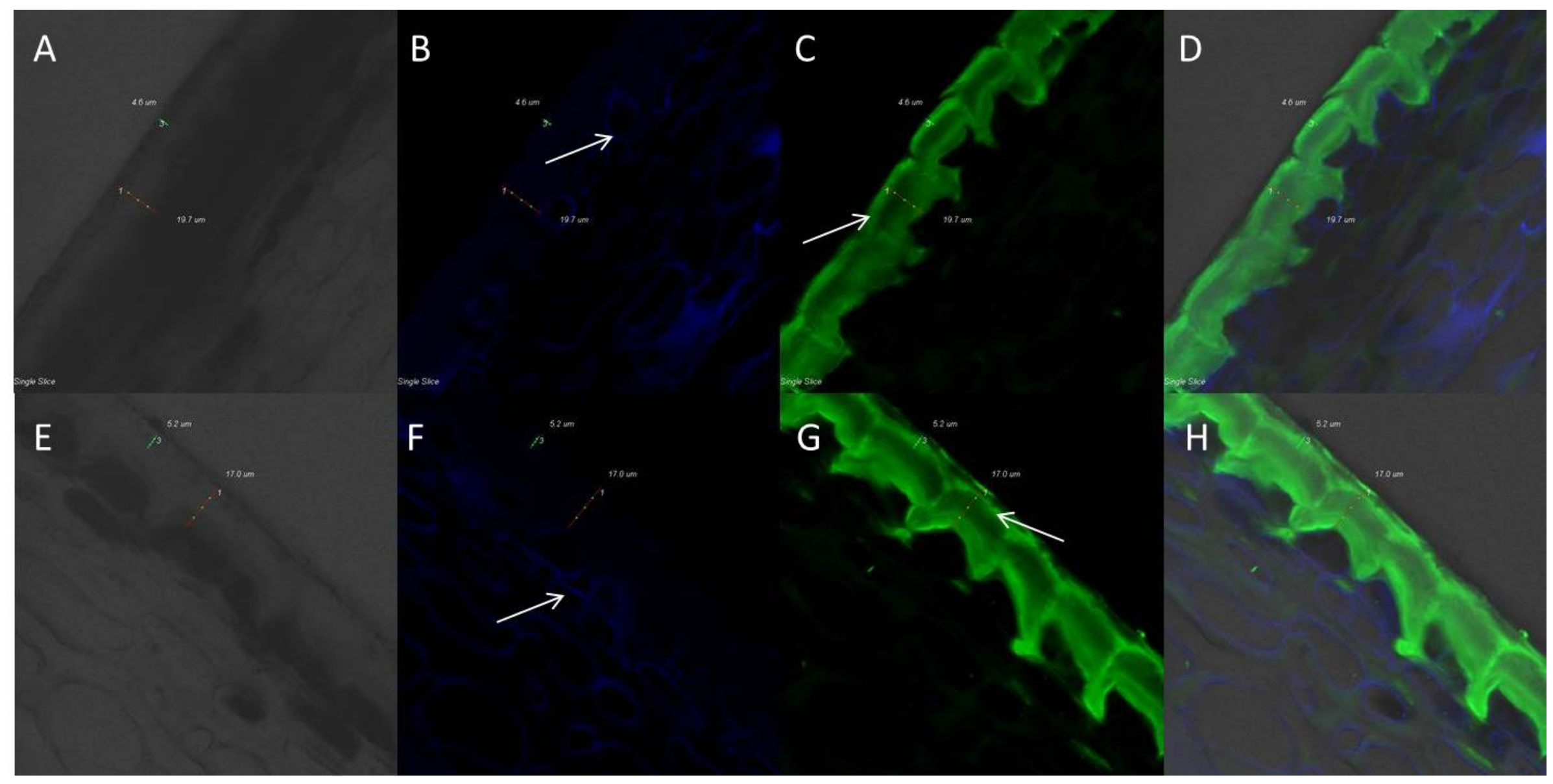

34. ábra: A 'Florina’ terméshéjak kutikulájának fluoreszcens mikroszkópos képei két reprezentatív mintán; balról jobbra haladva a hagyományos fénymikroszkópos képet (A, E), a Calcofluor White jelét $(B, F)$, az Auramin O festődés jelét $(C, G)$ majd ettől jobbra mindhármat egymásra rendezve láthatjuk $(D, H)$. 


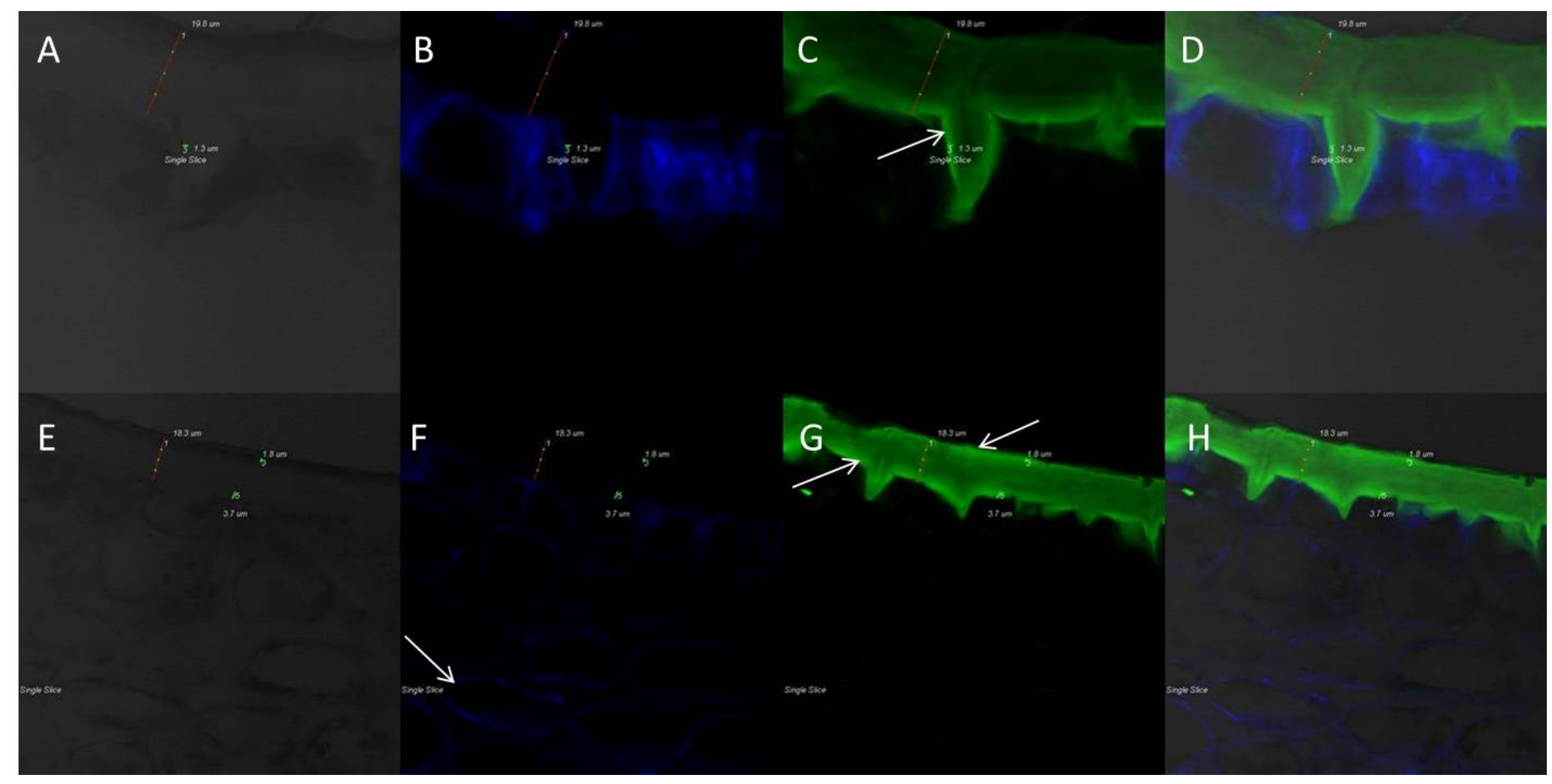

35. ábra: A ‘Prima’ terméshéjak kutikulájának fluoreszcens mikroszkópos képei két reprezentatív mintán; balról jobbra haladva a hagyományos fénymikroszkópos képet (A, E), a Calcofluor White jelét $(B, F)$, az Auramin O festődés jelét $(C, G)$ majd ettől jobbra mindhármat egymásra rendezve láthatjuk $(D, H)$. 
Mindkét fajta esetén erős festődést láthatunk az exokarpium feletti régiókban (egyöntetü zöld festődés a $\mathrm{C}$ és $\mathrm{G}$ ábrarészeken), míg a sejtfalak festődését követhetjük nyomon a parenchimális sejtsorokban, az exokarpium alatt (nyilakkal jelezve a B és F ábrarészeken). E mérésnél is különbség mutatkozik a kutikula vastagságában: a csupán apoláris régiókat megfestő Auramin O-val festődő réteg vastagsága a 'Prima' termés esetén

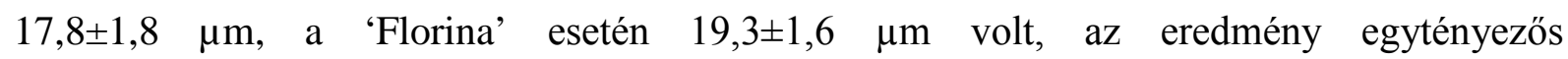
varianciaanalízissel került ellenőrzésre, a két csoport közti különbség szignifikáns 95\%-os szignifikanciaszinten. További eltéréseket találtunk a két fajta kutikuláris viaszrétegének ultrastrukturális tulajdonságaiban: a ‘Florina’ fajtánál az apoláris régió felső, külső környezet irányában lévő részén egy $6,1 \pm 2,4 \mu$ m-es (nyíllal jelezve a 34. ábra $C$ és $G$ ábrarészein), míg a

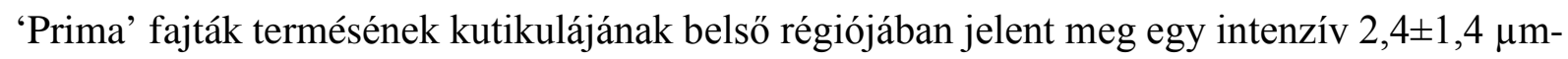

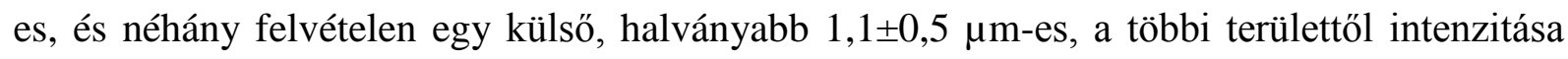
alapján élesen elkülöníthető sáv, réteg (nyilakkal jelezve a 35. ábra C és G részein).

\subsection{Az alma termések vízvesztésének meghatározása}

A posztharveszt párologtatás egy olyan gazdaságilag jelentős tulajdonság, melyre jelentős hatást gyakorol a kutikula, és annak ultrastruktúrája, így ezt is nyomon követtük a szedési érettségű termések betakarítását követően. A méréseket követően százalékban fejeztük ki a tömegeket, az első napi értékhez viszonyítva, és grafikonon ábrázolva regressziós egyenest illesztettünk rájuk a Microsoft Excel 2010 programmal, ez a 36. ábrán látható. 


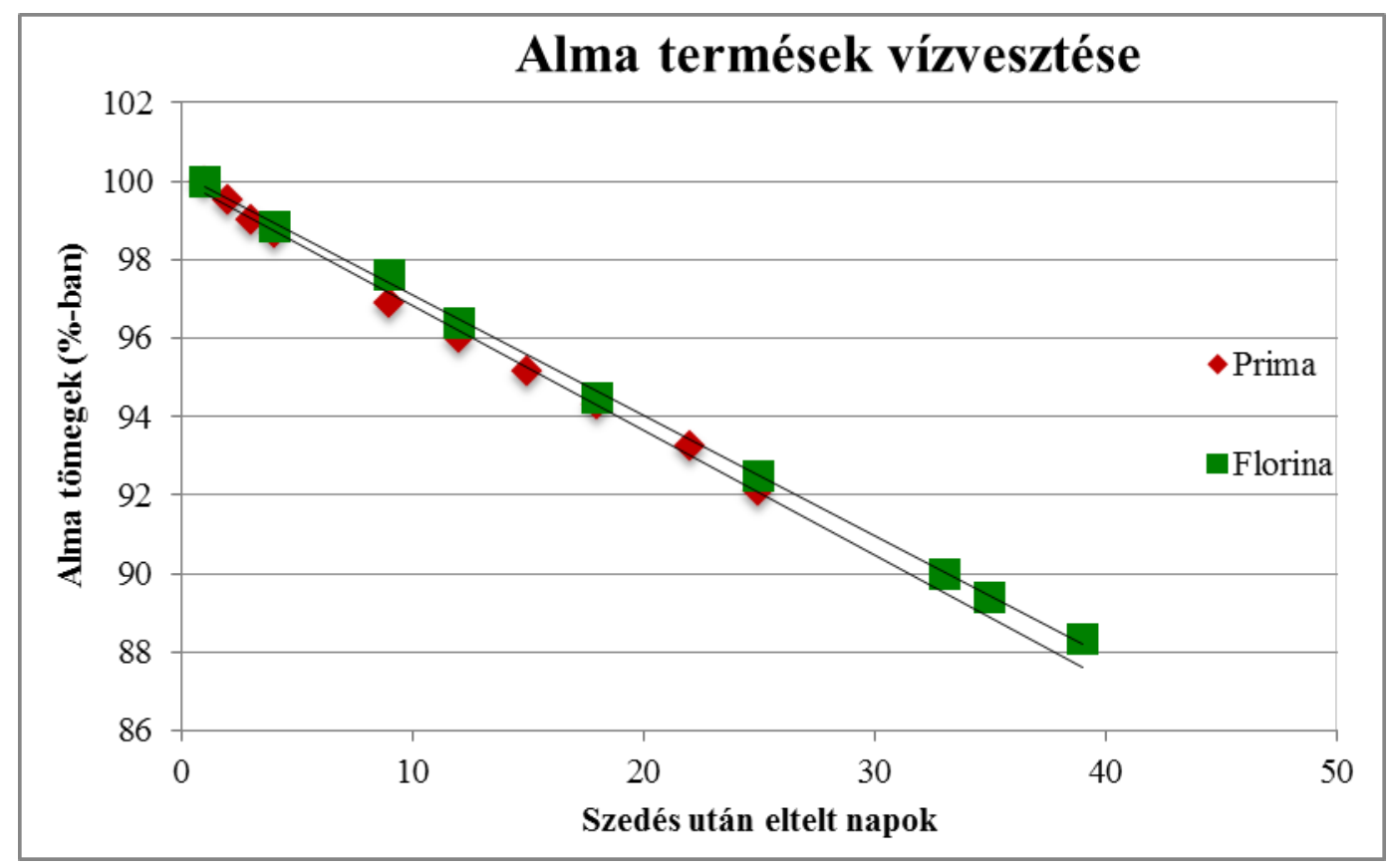

36. ábra: Az alma termések \%-ban kifejezett tömegcsökkenése a 2011-es mérések során. Zölddel a 'Florina', pirossal a 'Prima' almák méréseinek értékei láthatók, a hozzájuk tartozó lineáris regresszió egyenesével.

A regressziós görbék illesztésekor a legmagasabb $\mathrm{R}^{2}$ értékeket a lineáris illesztésnél kaptunk: 'Florina' esetén ez $\mathrm{R}^{2}=0,9991$, a 'Prima'-nál pedig $\mathrm{R}^{2}=0,9959$. Mindkét alma fokozatosan vesztett a tömegéből a posztharveszt tárolás alatt, a vizsgálat során betegség tüneteit mutató almákat azonnal eltávolítottuk a többi közül és kizártuk a vizsgálatból. A lineáris illesztések összehasonlítása nyomán a két alma vízvesztésének mértékében a gyakorlat szempontjából nem számottevő, azonban az értékelés szempontjából kimutatható és megemlítendő különbséget találtunk, ugyanis a két egyenes kezdőpontja azonos, a meredekségük viszont eltérő: ‘Florina': $y=-0,3073 x+100,18$, 'Prima': $y=-0,3185 x+100,2$.

\subsection{Az alma termések kutikuláris viaszrétegének vizsgálata}

A kutikuláris viaszok mennyiségi meghatározását két fejlődési állapotban vizsgáltuk 2010-ben (80\% körüli állapot, ami ‘Florina’ esetén 82\%-ot, 'Prima’ esetén 75\%-ot takart, és 100\%-os állapotok) és három érettségi állapotban 2011-ben (62\%, a 75/82\% és a 100\% állapotok). 2010-ben tíz-tíz darabból álló csoportot alakítottunk ki, párhuzamos mérések nélkül, míg 2011-ben mindegyik gyüjtésből három 7-7 darabos csoportot alakítottunk ki, és ezek kutikuláris viaszrétegét oldottuk be kloroformba, majd pároltuk be és mértük meg a szárazanyagok tömegét. Az eredmények között igen nagyfokú eltérést okozhat az egyes 
almák mérete, ezért a gyümölcsök felületegységére vonatkoztatott viaszmennyiségeket határoztunk meg. Az így kapott eredményeket a 37. és a 38. ábrákon mutatjuk be.

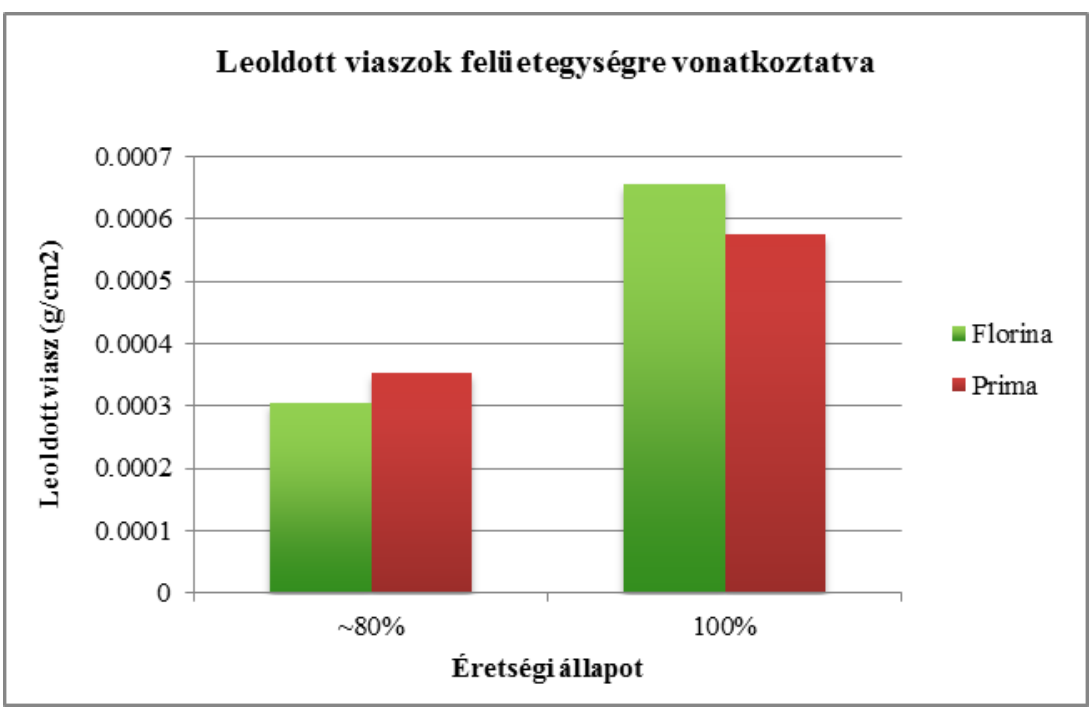

37. ábra: A 'Florina' és 'Prima' termések kutikuláris viasztömeg-meghatározásának eredményei 2010-ben.

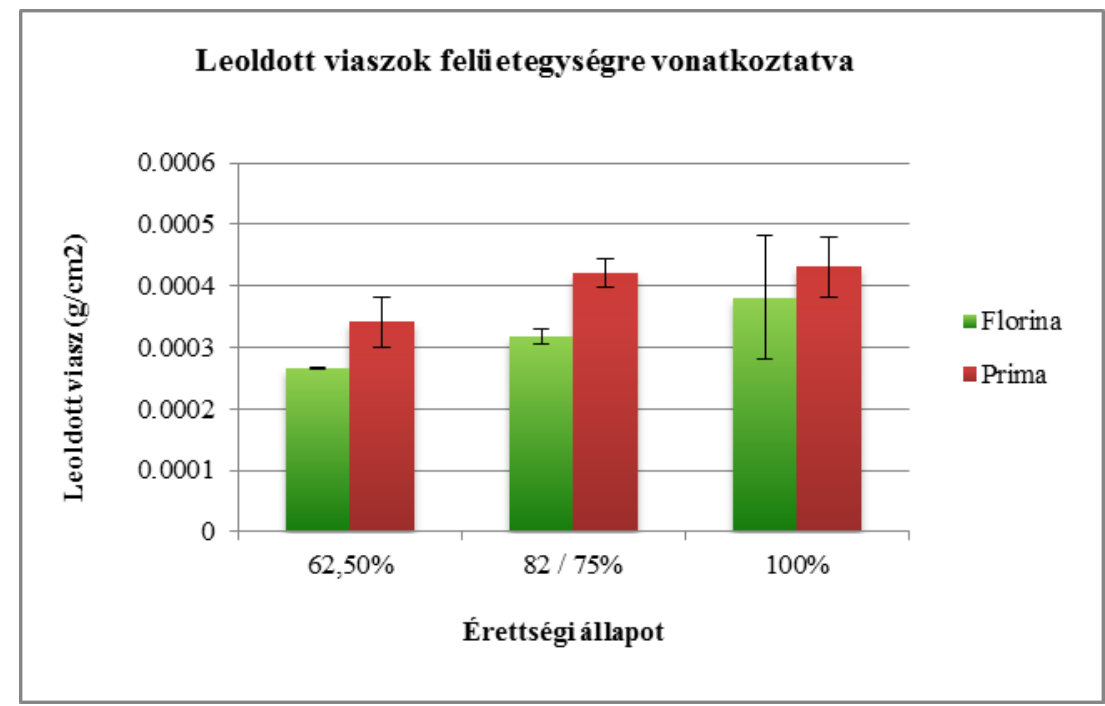

38. ábra: A 'Florina’ és 'Prima’ termések kutikuláris viasztömeg-meghatározásának eredményei 2011-ben.

A két fajta felületi viaszmennyiségei közötti különbségeket 2011-ben egytényezős varianciaanalízissel ellenőriztük, azonban ténylegesen bizonyítható különbséget csak a 82/75\%-os állapotban találtunk, az ez előtti és utáni állapotok eredményei statisztikailag nem voltak elkülöníthetők. 


\section{EREDMÉNYEK MEGVITATÁSA}

\subsection{Viasz-bioszintézissel összefüggő génexpressziós vizsgálatok almaszövetekben}

A kutikuláris viaszok bioszintézisében szerepet játszó gének azonosítása és jellemzése modellnövényben már megtörtént, illetve számos további gén esetén a vizsgálatuk folyamatban van. Az alma azért került vizsgálataink középpontjába, mert egy Magyarországon jelentős kertészeti haszonnövény egy lényeges tulajdonságáról, a gyümölcs felületi viaszképződéséről szerettünk volna ismereteket szerezni. Ezt az alma teljes genomszekvenciájának közzététele nagyban megkönnyítette. Egyéb kertészeti kultúrákban a viaszok bioszintézisében szerepet játszó gének vizsgálata csupán néhány kivételes esetben történt meg.

A kontrollként választott gének vizsgálata alapján azt mondhatjuk, hogy RT-PCR vizsgálatainkhoz az almaszövetekben megbízható és szemikvantitatívan megegyező expressziós jelet a tubulin és az ubikvitin gének esetén kaptunk. A Gasic és munkatársai által aktin génre tervezett primer használatát nem találtuk kielégítőnek a PCR termék viszonylag nagy mérete és a kifejeződés szöveti specifitása miatt, amiről a szerzők is beszámoltak (Gasic et al., 2004). Egy, az elongációs faktor $1 \alpha$ homológra tervezett primerpár használatát genomi DNS kontamináció szürésére kiválóan alkalmasnak ítéljük.

Az in silico módszerrel kiválasztott alma-beli KCS-homológok RT-PCR vizsgálata során megjelenő, terméshéjra specifikus és kismértékü levélbeni expresszió hasonló mintázatot mutat Joubés és munkatársai (2008) KCS génekkel lúdfüben végzett vizsgálatának eredményével. Ennek némiképp ellentmond azonban a KCS7/2 jelü gén levélben és héjban megjelenő expressziója, mely lúdfü esetén virágra és termésre mutatott specifitást. Az említett kutatócsoport eredményével szintén párhuzamba állítható a KCS4 génnel kapott eredményünk, amely lúdfü esetén is minden szövettájban kifejeződést mutatott. A homológ KCS gének izoformáinak eltérő szöveti specifitása a géntermékek eltérő funkcióira is utalhat, melyekre funkcionális vizsgálat deríthet a jövőben fényt. Joubés és munkatársai (2008) lúdfü esetén felhívták a figyelmet, ezen izoformák eltérő expressziójára különböző stresszek esetén, ilyen vizsgálatokat azonban mi nem végeztünk.

A CER1 gént lúdfüben az aldehid-alkán átalakulás kulcsenzimeként említik, müködését vizsgálták már búzában (Hu et al., 2009) és rozsban (Richardson et al., 2007). A 'Florina’ fajta gyümölcsviasz analízisének eredményeit korábban már közölték (Verardo et 
al., 2003), és a C29 alkánok felhalmozódását találták a vizsgálat során. Ezen viaszkomponens megjelenése összhangban áll az általunk talált feltételezett alma CER1 gén exokarpiális expresszióval.

A CER2 gén Arabidopsis thaliana-ban a virágzati szárban mutat specifikus expressziót (Joubés et al., 2011), a gén terméke pedig a C26-nál hosszabb zsírsavak lánchosszabbításában játszik szerepet (Jenks et al., 1995). Az általunk talált fajtaspecifitást nem mutató CER2 homológ szekvencia főként héjra és húsra jellemző expressziója egybevág a lúdfü CER2 gén NCBI Unigene oldalán talált expressziós profiljával.

A lúdfü CER4 génje egy acil-koenzim-A-reduktáz funkciójú fehérjét kódol, és a primer alkoholok kialakításában játszik szerepet (Rowland et al., 2006). Vizsgálatunk során egy alma CER4 homológ héjspecifikus expresszióját találtuk, ezt kiegészítve a 'Florina' fajta viaszanalízisének eredményeivel (Verardo et al., 2003), melyben a C30, C28 és C26 primer alkoholok felhalmozódását találták, azt mondhatjuk, hogy a fenti termékek a CER4 fehérje müködésének eredményei is lehetnek.

A CER5 gén az eddigi eredmények szerint lúdfüben a viaszkomponensek transzportjában játszik szerepet a WBC11-gyel közösen (Bird, 2008). Érdekes eredménynek tartjuk, hogy a CER5 és a WBC11 alma homológok egymással megegyező szövetspecifitású és erejü expressziós jelet mutattak a két évjáratban, ezt a David Bird által bemutatott heterodimer képződésével magyarázzuk. A viaszképződés jelenlegi modellje szerint a két gén terméke által képzett heterodimer együttesen képes a kutikuláris viaszok transzportját ellátni a sejtfal felé.

A feltételezett alma FDH, PAS2, WAX2 és CER10 homológ gének expresszióját erősnek találtuk a héjban, jóllehet megjelenésük nem korlátozódott kizárólagosan erre a szövettájra. A gyümölcs húsában megjelenő expressziójuk feltehetően a VLCFA-k triacilglicerolokká vagy szfingolipidekké történő átalakításában játszott szerepüket tükrözi.

A feltételezett alma HTH gén expressziója kizárólagosan a levél szövettájra korlátozódott, ez némiképp egybevág a lúdfüben talált expressziós mintázattal, ahol szárban és virágzatban detektálták a legerősebb jelet, ennél gyengébb jelet kaptak levélben, és még ennél is gyengébb jelet a gyökérben, illetve a becőkben (Krolikowski et al., 2003).

A KCR1 gén almabeli homológjának expressziója mindkét évjáratban a termés szöveteiben volt a legintenzívebb, a levélben csekély expressziós intenzitású jelet tudtunk 
detektálni. A KCR1 gén FAE-komplexben betöltött szerepe Arabidopsis thaliana-ban nélkülözhetetlennek bizonyult, hiányában embrionális letalitás lépett fel (Beaudoin et al., 2009). Az általunk kapott expressziós mintázat alapján arra is következtethetünk, hogy a lúdfühöz hasonlóan almában is hasonlóan számottevő funkciót láthat el, a gén expressziója egy cseresznyét érintő vizsgálat eredményével is egybevág (Alkio et al., 2012).

A LACS gének lúdfüben a kloroplasztiszból kikerült láncok észteresítési reakcióit katalizálják, és a kilenc azonosított LACS gén közül a LACS1 a viaszok, a LACS2 pedig a kutin bioszintézisében játszik szerepet (Shockey et al., 2002, Weng et al., 2010). Cseresznye vizsgálata során a LACS2 gén expressziójának fokozatos csökkenését mutatták be az érés során az exokarpiumban, a mezokarpiumban a gén kifejeződését nem tudták detektálni (Alkio et al., 2012). Az alma és cseresznye gyümölcsök szövettájainak eltérő ontogenezise miatt a köztük lévő génexpressziós viszonyokról nem szabad következtetést levonni, azonban a cseresznye exokarpiumában és alma exokarpiumában kifejeződő gének hasonló expresszióját valószínüsíthetjük, a gén expressziója cseresznyében az érés elörehaladtával csökken, vizsgálataink során almában a LACS homológ gén müködése 100\%-os érettségnél is kimutatható volt.

Az alma LCR homológ gén expresszióját héjspecifikusnak találtuk mindkét évjáratban, 'Florina’ fajtánál 2011-ben levélben is megjelent. A gén a kutin bioszintézisében tölt be fontos szerepet a zsírsavak $\omega$-hidroxilációja révén (Wellesen et al., 2011), eredményeink alapján a kutin bioszintézise az érett alma gyümölcsben is aktívan zajlik.

Az LTPG1 gén termékét lúdfüben a viaszkomponensek sejtfalon keresztül történő átjutását segítő fehérjeként azonosították (DeBono et al., 2009). Az alma LTPG homológ gén expressziós jelét levél és héj szövettájban intenzívnek, hús szövettájban nagyon gyengének vagy nem detektálhatónak találtuk. Ez az eredmény összefügghet az alma LTPG1 viaszkomponens-transzferben betöltött szerepével, a gyümölcshúsbeli alacsony expresszióját ez legalábbis mindenképp magyarázza.

A lúdfü WIN1 gén a kutatások szerint a CER1, KCS1, LACS2 és CER2 gének transzkripciós faktora (Broun et al., 2004, Kannangara et al., 2007). A hozzá hasonló alma szekvencia általában gyenge expressziós jelet mutatott, 'Florina’ esetén a levél és héj, 'Prima' esetén a héj szövettájban 2011-ben. Az említett, általa feltételezhetően szabályozott gének közül az alma LACS2 homológ gén expressziója mutatott hasonló profilt a WIN1-ével, a többi gén esetén a kérdéses szövettájak mindegyikében kaptunk expressziós jelet. 
A kutin bioszintézisében szereplö LACS2, LCR és WIN1 gének alma homológjainak 2011-ben megjelenő azonos mintázatú expressziója alátámasztja azt a feltételezést, hogy ezek a gének a közös bioszintetikus folyamatban játszhatnak szerepet, ez pedig a kutin bioszintézise lehet.

\subsection{A kutikula szerepe az alma termés vízháztartásában}

A vizsgált ‘Florina’ és ‘Prima’ (téli és nyári alma) fajták gyümölcseinek betakarítás utáni, szobahőmérsékleten, $\mathrm{kb} 60 \%$ relatív páratartalom melletti tárolás során mért vízvesztésében a fajták között csak kismértékủ különbséget találtunk. A tárolás körülményeit azért így választottuk meg, mert feltételezhető volt, hogy a gyümölcs belső tere és a kis vízgőz tartalmú szabad levegő közötti nagy vízpotenciál grádiens fokozottan mérhetővé teszi a kutikula párologtatást gátló hatásának különbségeit. Ennek ellenére a vízvesztésben tapasztalt különbség nem volt számottevő. Adataink alapján feltételezhetjük tehát, hogy a vizsgált almafajták tárolhatóságának különbségét nem a kutikula vízáteresztésében meglevő különbség határozza meg. Különösen igaz lehet ez a tárolók magas páratartalmú légterét is számításba véve. Feltételezhető, hogy a tárolhatóságot más bélyegek, például a klimaktérium intenzitása és gyorsasága befolyásolhatja. Ebben azonban a kutikulának szintén szerepe lehet, hiszen a klimaktériumban termelődő etilén számára a gyümölcs kutikulája diffúziós gátat jelenthet. Ebben az irányban azonban egyelöre nem végeztünk vizsgálatokat. A kutikula vastagságát Ghafir et al. (2009) sem találták jellemzőnek a hütött, alacsony hőmérsékleten történő tárolhatóságra nézve, amennyiben a rosszul tárolható 'Gala' fajta kutikuláját különösen vastagnak találták.

Kísérleteink egy meglepő eredménye az, hogy a kutikulák mért vastagsága nem állt egyenes arányban a felszínről extrahálható lipidek mennyiségével. A felületegységre vonatkoztatott viaszmennyiségekben az egymást követő években történt mérések során jelentkező különbséget a két év közötti évjárathatással magyarázzuk. A különböző stresszek ugyanis jelentős hatást képesek kifejteni a kutikulára, és így a kutikuláris viaszok termelődésére (Shepherd és Griffiths, 2006), ezért sem meglepő, hogy az egymás utáni évek mérései nem reprodukálták egymást teljesen.

Lényeges különbséget találtunk azonban a kutikula mikroszkópos vizsgálata során, a vékonyabb kutikulájú 'Florina' fajta külső rétegében, a vastagabb kutikulájú 'Prima' fajta kutikulájának pedig az belső régiójában találtunk intenzívebb Auramin O-festődést. Úgy gondoljuk, hogy a kutikula strukturáltságának szerepe lehet a tárolhatóság kialakításában. A 
kutikula ultrastruktúrájának fluoreszcens képalkotással készült felvételét mutatták be Buda és munkatársai is, az intenzívebben festődő régiókat az intrakutikuláris, a kevésbé intenzív jelü területeket külső kutikuláris régióként ismertették. A kutatócsoport ezt a rétegződést a kutikuláris viasz komponenseinek eltérő elhelyezkedésével magyarázta (Buda et al., 2009). Eredményeink alapján elmondható, hogy a kutikulájuk tekintetében az általunk vizsgált két almafajta különbségeket mutat, úgy a teljes kutikuláris réteg vastagságát, mint annak ultrastruktúráját tekintve. Feltételezzük, hogy inkább az ultrastrukturális különbség játszhat szerepet a két fajta eltérő tárolhatóságának kialakulásában, de valószínűleg nem az eltérő kutikuláris párologtatási rátán keresztül .

\subsection{A kutikula szerepe a paprika termés vízháztartásában}

A 'Titán' és 'Hó' fajtájú paprikák terméseinek vízháztartása között jelentős különbségeket találtunk. A WLR és az összes WLR vizsgálata alapján azt mondhatjuk, hogy a ‘Titán’ paprikák több vizet párologtattak a tárolás során a 'Hó’ terméseinél. A két fajta pulton tarthatóságáról megfigyelések állnak csupán rendelkezésre, a 'Titán’ paprikák hamar fonnyadtak, vizsgálatunk során ezt mérésekkel dokumentáltuk: a kloroformmal kezelt paprikák össztömegük közel 80-90\%-át veszítették el a tárolás alatt, fejlettségi állapotuk függvényében, a kezeletlen paprikáknál ugyanez az arány 20-30 \% körüli volt. Bár a kezeletlen paprikák összes tömegvesztésük alapján nem mutattak jelentős eltérést a vizsgált tényezők tekintetében, a kezelés hatására különbségeket találtunk az érettségi állapotok között is: a félméretű és éretlen állapotú paprikák elkülöníthetőek voltak az érett állapottól, ezek a kezelést követően többet párologtattak az éretlen állapotúaknál. A paprikák érettségi állapotai közötti különbségek és a vízvesztés kapcsolatának vizsgálata során azt találták, hogy a legkisebb tömegü paprikák vesztették a legtöbb vizet a tárolási periódus alatt, a tömegek növekedésével a párologtatás mértéke aszimptotikusan csökkent (Díaz-Pérez et al., 2007). Az említett cikkben közölt eredmények eltérései a vizsgálataink során kapottaktól több okból is fakadhatnak. A cikkben vizsgált 'Camelot' fajta Blocky típusú paprika, a 'Titán’ és 'Hó' fajták a Cecei típusú paprikák közé tartoznak, a két fajta WLR értékeinek különbségei a szerzők által használt képlettel számított WLR értékeiben (összes WLR \%-ban kifejezve, osztva a napok számával és a légnyomás értékével) is megmutatkoznak: a Blocky típusúaknál ez 0,5 körüli, a mi értékeink a fentiek szerint korrigálva 0,2 körül alakulnak. A szerzők mindezek mellett vizsgálatukban a kocsányon keresztül történő párologtatást nem küszöbölték ki, így az általuk közölt WLR eredmények a kocsányon keresztül történő párologtatást is magukba foglalják. A kloroformmal kezelt termések közül az éretlen állapotban lévő, fiatal 
paprikák vesztették a legtöbb vizet, és érdekes módon a kontrolloknál látott tendencia a kezelt mintákon is megfigyelhető volt, ezen mintáknál is a 'Hó' termései vesztettek több vizet. A kloroformozott minták vízvesztésének ugrásszerü növekedése arra utal, hogy a sztómamentes paprikatermés vízháztartásában és annak szabályozásában a kutikula kulcsfontosságú szerepet tölt be.

A 'Hó’ és 'Kárpia’ paprikák pulton tarthatóságáról rendelkezésre álló információk alapján a vízvesztésük összehasonlítása korábban már megtörtént (Zsom, 2007), és meglepő módon a 'Kárpia' termések bár hosszabban pulton tarthatók, több vizet veszítenek. Zsom Tamás doktori értekezésében beszámol arról, hogy hütőtárolás alatt a tömegváltozás tekintetében az egyes étkezési paprikák érettségi állapotai között apróbb eltérések voltak leírthatók, azonban ezeket statisztikailag nem sikerült alátámasztni. A tömegvesztésre szolgáló magyarázatként döntő mértékben a bogyó belső tere és környezete közötti vízgőznyomás-differenciától függő párologtatást adta meg. Az étkezési paprikák tömegvesztésének vizsgálata a mi kísérletsorozatunkban a paprika termések mikroszkópos analízisével egészült ki, a kapott eredmények a szöveti különbségekkel is összefüggésbe hozhatók.

Egyes paprikafajták között az exokarpium különbségei már korábban is ismertek voltak, például a régebbi és újabb paprikafajták esetén (Balázs, 1994), ezt vizsgálataink során két vizsgált fajta esetében mikroszkópos módszerek segítségével megerősítettük. Az érett állapotú ‘Titán’ paprikák esetén ugyanis 2-3 sejtsorból álló hipodermális kollenchimát sikerült azonosítani, emellett a 'Titán' terméseket borító kutikularéteg vastagabb volt a 'Hó' terméseken találhatónál, az érés előrehaladtával a 'Hó' fajtán a kutikula vastagsága csökkent (Albert et al., 2011). A kutikula vastagsága ugyan nagyobb volt a ‘Titán’ fajtánál, azonban a kutikuláris viaszok felületegységre vonatkoztatott mennyisége épp a 'Hó' fajta terméseinél volt nagyobb, ez valószínűleg a kutikula struktúrájának különbségeiből fakadhat, a kutikula nagyobb vastagságát viasz híján feltehetően a kutin struktúra okozhatja. Eredményünk azt a feltételezést támasztja alá, hogy a kutikula vastagsága és a növény vízmegtartó képessége között közvetlen összefüggés nem áll fenn, erről már más kutatók is beszámoltak (Smith et al., 2006). Az eredmények alapján arra következtethetünk, hogy a kutikuláris viaszok összetételében, strukturáltságában meglevő különbség okozhatja a vízmegtartás eltérő mértékét a fajták között. Ez utóbbi kijelentés összhangban állhat azzal, hogy a 'Hó’ és 'Titán’ termések kutikuláris viaszaiban az érés elörehaladtával kvaliltatív különbségeket és változásokat találtunk (Nagy et al., 2011). 
A felszíni viaszok leoldása után a 'Hó’ termésein találtunk több viaszt felületegységre vonatkoztatva. A ‘Kárpia’ termésein lévő kutikuláris viasz mennyisége olyan csekély, hogy az egy évvel korábbi mérésben a tárolás során fonnyadásra kifejezetten hajlamos 'Titán' termésein is többet találtunk. Ezen eredményeket összegezve megerösíthetjük eredményeinkkel azt a feltételezést, hogy a kutikuláris viaszok mennyisége önmagában nem befolyásolja a posztharveszt párologtatás mértékét. A 'Kárpia' paprikák kutikulája vastagabbnak bizonyult a 'Hó' fajta termésein található kutikularétegnél, amik között strukturális különbséget is felfedeztünk. A kutikula mellett a periklinális sejtfal vastagságában, a hipodermális kollenchima sejtrétegeinek számában, az exokarpium és a kollenchima együttes vastagságában és a kollenchimatikus sejtek sejtfalainak vastagságában is magasabb értékeket találtunk a 'Kárpia' termései esetén (Albert et al., 2012). Feltételezhetjük tehát, hogy inkább ezekből a szövetszerkezeti különbségekből eredő jobb fizikai tartás, semmint a kutikulán át történő vízvesztés különbségei állhatnak a 'Kárpia’ jobb pulton tarthatóságának hátterében. 


\section{8. ÚJ TUDOMÁNYOS EREDMÉNYEK}

1. Megbízhatóan müködő referenciagéneket találtunk alma szövetekben zajló génexpresszió vizsgálatára RT-PCR és RT-qPCR eljárásokhoz.

2. cDNS genomi DNS szennyeződésének kimutatására egy intron-tartalmú szekvenciára tervezett primerpárt vezettünk be almában, mellyel a genomi DNS zavaró jelenléte nagy biztonsággal szürhető.

3. Héjspecifikusan expresszálódó, a kutikula alkotóinak-bioszintézisében feltehetően szerepet játszó gének müködését mutattuk ki almában.

4. 'Prima’ és ‘Florina’ termések mikroszkópos vizsgálata során különbségeket tártunk fel a kutikulájuk vastagságában és szerkezetében.

5. Jellemeztük a 'Hó' és 'Titán’ paprikák vízvesztését három érettségi állapotban, különbségeket tártunk fel a két fajta, és a három érettségi állapot között is a vízvesztés tekintetében.

6. A ‘Hó’ és 'Kárpia’ paprikák kutikuláris viaszfedettsége és a kutikulájuk szerkezete között különbségeket írtunk le. A ‘Kárpia’ fajta esetében a jobb pultontarthatóság ellenére a bogyók magasabb vízvesztését találtuk, így ebben az esetben az eltarthatóság és a párologtatás mértéke közötti feltételezett egyenes arányossági kapcsolatot elvetettük. 


\section{9. ÖSSZEFOGLALÁS}

A növényi kutikula elsődleges határolóréteg a növények földfelszíni szervein, szerepe létfontosságú a különböző biotikus és abiotikus stresszek elleni védekezésben. Vizsgálataink során célul tüztük ki a növényi kutikula vízháztartásra gyakorolt hatásának vizsgálatát különböző fajtájú paprika termések és alma termések esetén, valamint célunk volt a kutikuláris viaszok bioszintézisében feltételezhetően szerepet játszó gének vizsgálata alma különböző szövettájaiban.

In silico módszerek felhasználásával kontrollgéneket választottunk ki, melyek expresszióját referenciaként alkalmaztunk későbbi vizsgálatainkban. A kiválasztott gének közül az ubikvitin és a tubulin bizonyultak stabilan kifejeződőnek a különböző szövettájakban, egy EF1 $\alpha$ homológot pedig alkalmasnak találtuk a RT-PCR alapú módszer során a zavaró genomi DNS szürésére. Szintén in silico módszerekkel a lúdfüben müködő viasz-bioszintézisben szerepet játszó gének segítségével azok alma-beli homológjait kívántuk azonosítani, majd később kísérletesen expressziójukat jellemezni. A szelektált gének többsége aminosav-szinten vizsgálva nagyfokú hasonlóságot mutat a lúdfü-beli homológjával. A kiválasztott gének közül többnél is sikerült RT-PCR módszerrel héjspecifikus expressziót találnunk, ilyenek voltak a KCS7/2, a KCS14, a CER1, a CER4, a CER5, a FDH, a LCR, a PAS2 és a WAX2 homológok, a kifejezödésbeli különbséget kvantitatív módon a LCR homológ esetén qPCR-rel erősítettük meg. A viaszkomponensek transzportjában szereplő CER5 és WBC11 homológok expressziós profilját egymással összepárosíthatónak találtuk.

Az almák vízháztartásában számottevő különbséget nem találtunk, de a termésének kutikulájában a vizsgált két fajta esetében különbségeket tártunk fel. A nyári 'Prima' fajta kutikulája vastagabb volt a 'Florina’ fajtáénál. Konfokális lézer pásztázó mikroszkópos módszerrel a 'Florina’ termések kutikulájának felszíni régiójában, a 'Prima’ termések kutikulájának bőrszövet felöli részén találtunk erősebb apoláris jellegủ réteget. Ez alapján a két fajta között egyértelmü, a kutikuláris ultrastruktúrában jelentkező különbségről számolhatunk be.

A 'Hó’ és ‘Titán’ paprikák posztharveszt vízvesztésének nyomonkövetésével jellemeztük vízháztartásukat, és a ‘Titán’ paprikákat kevésbé jó vízmegtartónak találtuk. A termések érettségi állapotát a fajta mellett egy további jelentős befolyásoló tényezőként azonosítottuk a vízvesztésben. A fajták között eltérés mutatkozott a felszínre vonatkoztatott viaszok mennyiségében is, azonban ahogyan több kutató is rámutatott, önmagában sem a 
kutikula vastagsága sem pedig a kutikuláris viaszok mennyisége nincs közvetlen és egyértelmü összefüggésben a posztharveszt vízvesztés mértékével.

A 'Hó’ és 'Kárpia' fajtákkal végzett vizsgálatunk során jelentős különbségeket találtunk a felületegységre vonatkoztatott viaszok mennyiségében, és a kutikula struktúrájában is. Eredményeink szerint azonban a 'Kárpia' paprikák vízvesztése nem alacsonyabb (sőt magasabb) a 'Hó’ fajtájúéknál, a ‘Kárpia’ jobb pultontarthatósága tehát nem eredhet az kisebb párologtatásból. Valószínübb magyarázatul szolgálhatnak a fajták tulajdonságaira az exokarpium szövettani vizsgálatai. 


\section{SUMMARY}

The cuticle is a primary barrier of the aerial organs of plants towards the athmosphere that plays an important role in the defense against several biotic and abiotic stresses. We aimed to examine the effect of the plant cuticle on water relations in the fruits of different cultivars of apple and pepper. We also aimed to identify genes potentially involved in cuticle formation of apple fruit.

Using in silico methods we chose some control genes that were used as reference genes in further experiments. Among all, ubikvitin and tubulin showed stabile expression in the different apple tissues, while an EF1 $\alpha$ homolog gene is found to be a possible genomic DNA contamination marker in RT-PCR experiments. Amino acid sequences of the selected apple genes showed high similarity to the corresponding thale cress sequences. Peel-specific expression was found in the case of KCS7/2, KCS14, CER1, CER4, CER5, FDH, LCR, PAS2, WAX2 homologs. The difference in the expression level was quantified by qPCR method in the case of the LCR homolog. The putative transport-related CER5 and WBC11 homologous genes showed parallel expression pattern.

While we could not find significant differences in water relations of fruits from the two apple cultivars under investigation, major differences in the structure of the cuticles were shown. The 'Prima' cultivar has thicker cuticle than that of 'Florina' apples, and furthermore, in the outermost layer of 'Florina' and the basal region of 'Prima' cuticles intense staining was observed, indicating the accumulation of lipophilic substances in that region. Altogether our results show major ultrastructural differences between the cuticles of the two cultivars.

Following the postharvest water-loss rates of 'Hó' and 'Titán’ pepper fruits we studied their water relations, and we found 'Titán' cultivar generally to lose more water per surface unit area. The developmental stage of the fruits showed to have an impact on the rate of water-loss, which was also cultivar specific. We also found differences in the total amount of cuticular wax per surface area unit, but like many other studies suggest, neither the thickness of the cuticle, nor the total amount of cuticular waxes could be identified as exact and determining factors in the rate of postharvest water-loss.

We found major differences in the total amount of cuticular waxes per surface area unit and also in the cuticular structure of'Hó' and 'Kárpia' pepper fruits. Our results indicated that despite longer shelf life 'Kárpia' fruits display higher rate of water loss. This suggests 
that water relations are not determining factors in storability of 'Kárpia' fruits. A most probable explanation comes from results of studying structures of the exocarp tissues of fruits. 


\section{IRODALOMJEGYZÉK}

1. AARTS, M. G. M., KEIJZER, C. J., STIEKEMA, W. J., PEREIRA, A. (1995.) Molecular characterization of the CER1 gene of Arabidopsis involved epicuticular wax biosynthesis and pollen fertility. The Plant Cell 7. 2115-2127. DOI: 10.1105/tpc. 7.12.2115

2. ALBERT, ZS., KUZNYÁK, L., DEÁK, CS., MISKÓ, A., ERÖS-HONTI, ZS., HÖHN, M., TERBE, I., PAPP, I. (2011.) Kutikuláris viaszok és bőrszöveti struktúrák szerepe két paprikafajta termésén a posztharveszt vízvesztés szabályozásában. Erdei Ferenc VI. Tudományos Konferencia III. kötet, 199-204. Kecskemét. (ISBN 978-6155192-01-2)

3. ALKIO, M., JONAS, U., SPRINK, T., VAN NOCKER, S., KNOCHE, M. (2012) Identification of putative candidate genes involved in cuticle formation in Prunus avium (sweet cherry) fruit. Annals of Botany 110. (1.) 101-112. DOI: 10.1093/aob/mcs087

4. ALONI, B., KARNI, L., RYLSKI, I., COHEN, Y., LEE, Y., FUCHS, L. M., MORESHET, S., YAO, C. (1998.) Cuticular cracking in pepper fruit. I. Effects of night temperature and humidity. Journal of Horticultural Science \& Biotechnology 73. (6.) 743-749.

5. ALTSCHUL, S. F., MADDEN, T. L., SCHÄFFER, A. A., ZHANG, J., ZHANG, Z., MILLER, W., LIPMAN, D. J. (1997.) Gapped BLAST and PSI-BLAST: a new generation of protein database search programs. Nucleic Acids Research 25. 33893402.

6. AROndel, V., Vergnole, C., CANTREL, C., KADER, J. C. (2000.) Lipid transfer proteins are encoded by a small multigene family in Arabidopsis thaliana. Plant Science 157. 1-12.

7. ASIF, M., TRIVEDI, P., SOLOMOS, T., TUCKER, M. (2006.) Isolation of highquality RNA from apple (Malus domestica) fruit. Journal of Agricultural and Food Chemistry 54. 5227-5229. DOI: 10.1021/jf053137n

8. BACH, L., FAURE, J. D. (2010.) Role of very-long-chain fatty acids in plant development, when chain length does matter. C. R. Biologies 333. 361-370. DOI: 10.1016/j.crvi.2010.01.014 
9. BACH, L., MICHAELSON, L. V., HASLAM, R., BELlEC, Y., GISSOT, L., MARION, J., DA COSTA, M., BOUTIN, J. P., MIQUEL, M., TELlIER, F., DOMERGUE, F., MARKHAM, J. E., BEAUDOIN, F., NAPIER, J. A., FAURE, J. D. (2008.) The very-long-chain hydroxy fatty acyl-CoA dehydratase PASTICCINO2 is essential and limiting for plant development. PNAS 105. (38.) 14727-14731. DOI: 10.1073/pnas.0805089105

10. BALÁZS, S. (1994.) Zöldségtermesztők kézikönyve. Mezőgazda Kiadó, Budapest. ISBN: 9638439378

11. BAUD, S., GUYON, V., KRONENBERGER, J., WUILlEME, S., MIQUEL, M., CABOCHE, M., LEPINIEC, L., ROCHAT, C. (2003.) Multifunctional acetyl-CoA carboxylase 1 is essential for very long chain fatty acid elongation any embryo development in Arabidopsis. The Plant Journal 33. 75-86. DOI: 10.1046/j.1365313X.2003.016010.x

12. BAUER, S., SCHULTE, E., THIER, H. P. (2004a.) Composition of the surface wax from tomatoes I. Identification of the components by GC/MS. European Food Research and Technology 219. 223-228. DOI: 10.1007/s00217-004-0943-0

13. BAUER, S., SCHULTE, E., THIER, H. P. (2004b.) Composition of the surface wax from tomatoes II.Quantification of the components at the ripe red stage and during ripening. European Food Research and Technology 219. 487-491. DOI: 0.1007/s00217-004-0944-z

14. BEAUDOIN, F., WU, X., LI, F., HASLAM, R. P., MARKHAM, J. E., ZHENG, H., NAPIER, J. A., KUNST, L. (2009.) Functional characterization of the Arabidopsis $\beta$ ketoacyl-Coenzyme A reductase candidates of the fatty acid elongase. Plant Physiology 150. 1174-1191. DOI: 10.1104/pp.109.137497

15. BEISSON, F., KOO, A. J. K., RUUSKA, S., SCHWENDER, J., POLLARD, M., THELEN, J. J., PADDOCK, T., SALAS, J. J., SAVAGE, L., MILCAMPS, A., MHASKE, V. B., CHO, Y., OHLROGGE, J. B. (2003.) Arabidopsis genes involved in acyl lipid metabolsim. A 2003 census of the candidates, a study of the distribution of expressed sequence tag sin organs, and a web-based database. Plant Physiology 132. 681-697. DOI: $10.1104 /$ pp.103.022988

16. Beisson, F., LI, Y., BONAVENTURE, G., POLlARD, M., OHLROGGE, J. B. (2007.) The acyltransferase GPAT5 is required for the synthesis of suberin in seed coat and root of Arabidopsis. The Plant Cell 19. 351-368. DOI: 10.1105/tpc.106.048033 
17. BESSIRE, M., CHASSOT, C., JACQUAT, A. C., HUMPHRY, M., BOREL, S., PETÉTOT, M. C. J., NAWRATH, C. (2007.) A permeable cuticle in Arabidopsis leads to a strong resistance to Botrytis cinerea. The EMBO Journal 26, 2158-2168. DOI: 10.1038/sj.emboj.7601658

18. BILES, C. L., WALL, M. M., WAUGH, M., PALMER, H. (1993.) Relationship of Phytophtora fruit rot to fruit maturation and cuticle thickness of New Mexican-type peppers. Phytopathology 83. 607-611.

19. BIRD, D.A. (2008.) The role of ABC transporters in cuticular lipid secretion. Plant Science 174. 563-569. DOI: 10.1016/j.plantsci.2008.03.016

20. BIRD, D., BEISSON, F., BRIGHAM, A., SHIN, J., GREER, S., JETTER, R., KUNST, L., WU, X., YEPHREMOV, A., SAMUELS, L. (2007.) Characterization of Arabisopsis ABCG11/WBC11, an ATP binding casette (ABC) transporter that is required for cuticular lipid secretion. The Plant Journal 52. 485-498. DOI: 10.1111/j.1365-313X.2007.03252.x

21. BiSIO, A., CORAllO, A., GASTAlDO, P., ROMUSSI, G., CIARALlO, G., FONTANA, N., DE TOMMASI, N., PROFUMO, P. (1999.) Glandular hairs and secreted material in Salvia blepharophylla Brandegee ex epling grown in Italy. Annals of Botany 83. 441-452. DOI: DOI: 10.1006/anbo.1998.0838

22. BONAVENTURE, G., SALAS, J. J., POLLARD, M. R., OHLROGGE, J. B. (2003.) Disruption of the FATB gene in Arabidopsis demonstrates an essential role of saturated fatty acids in plant growth. The Plant Cell 15. 1020-1033. DOI: 10.1105/tpc.008946

23. BOURDENX, B., BERNARD, A., DOMERGUE, F., PASCAL, S., LÉGER, A., ROBY, D., PERVENT, M., VILE, D., HASLAM, R. P., NAPIER, J. A., LESSIRE, R., JOUBÉS, J. (2011.) Overexpression of Arabidopsis ECERIFERUM1 promotes wax very-long-chain alkane biosynthesis and influences plant response to biotic and abiotic stresses. Plant Physiology 156. 29-45. DOI: 10.1104/pp.111.172320

24. BOX, G. E. P., COX, D. R. (1964.) An analysis of transformations. Journal of the Royal Statistical Society, Series B 26. (2.) 211-252. DOI: 10.1.1.321.3819

25. BROUN, P., POINDEXTER, P., OSBORNE, E., JIANG C. Z., RIECHMANN, J. L. (2004.) WIN1, a transcriptional activator of epidermal wax accumulation in Arabidopsis. PNAS 101. (13.) 4706-4711. DOI: 10.1073/pnas.0305574101 
26. BRUNNER, A. M., YAKOVLEV, I. A., STRAUSS, S. H. (2004.) Validating internal controls for quantitative plant gene expression studies. BMC Plant Biology 4. (14.) DOI: $10.1186 / 1471-2229-4-14$

27. BUDA, G. J., ISAACSON, T., MATAS, A. J., PAOLILLO, D. J., ROSE, J. K. C. (2009.) Three-dimensional imaging of plant cuticle architecture using confocal scanning laser microscopy. The Plant Journal 60. 378-385. DOI: 10.1111/j.1365313X.2009.03960.X

28. BUSCHHAUS, C., JETTER, R. (2011.) Composition differences between epicuticular and intracuticular wax substructures: How do plants seal their epidermal surfaces? Journal of Experimental Botany 62. (3.) 841-853. DOI: 10.1093/jxb/erq366

29. CAMERON, K. D., TEECE, M. A., SMART, L. B. (2006.) Increased accumulation of cuticular wax and expression of lipid transfer protein in response to periodic drying events in leaves of tree tobacco. Plant Physiology 140. 176-183. DOI: 10.1104/pp.105. 069724

30. CHATTERJEE, S., SARKAR, S., OKTAWIEC, J., MAO, Z., NIITSOO, Z., STARK, R. E. (2012.) Isolation and biophysical study of fruit cuticles. Journal of Visualized Experiments 61. e3529 10.3791/3529, DOI: 10.3791/3529.

31. CHIBNALL, A. C., PIPER, S. H., POLLARD, A., SMITH, J. A. B., WILLIAMS, E. F. (1931.) The wax contituents of the apple cuticle. Biochemistry Journal 25. (6.) 2095-2110.

32. CHEN, X., GOODWIN, S.M., BOROFF, V.L., LIU, X., JENKS, M.A. (2003.) Cloning and characterization of the WAX2 gene of Arabidopsis involved in cuticle membrane and wax production. The Plant Cell 15. 1170-1185. DOI: 10.1105/tpc.010926

33. COSTA, F., ALBA, R., SCHOUTEN, H., SOGLIO, V., GIANFRANCESCHI, L., SERRA, S., MUSACCHI, S., SANSAVINI, S., COSTA, G., FEI, Z., GIOVANNONI, J. (2010.) Use of homologous and heterologous gene expression profiling tools to characterize transcription dynamics during apple fruit maturation and ripening BMC Plant Biolology 10. 229. DOI: 10.1186/1471-2229-10-229.

34. DEBONO, A., YEATS, T. H., ROSE, J. K. C., BIRD, D., JETTER, R., KUNST, L., SAMUELS, L. (2009.) Arabidopsis LTPG is a glycosylphosphatidylinositol-anchored lipid transfer protein required for export of lipids to the plant surface. The Plant Cell 21. 1230-1238. DOI: 10.1105/tpc.108.064451 
35. DÍAZ-PÉREZ, J. C., MUY-RANGEL, M. D., MASCORRO, A. G. (2007.) Fruit size and stage of ripeness affect postharvest water loss in bell pepper fruit (Capsicum annuum L.) Journal of the Science of Food and Agriculture 87. 68-73. DOI: 10.1002/jsfa.2672

36. DITTRICH-DOMERGUE， F., PASCAL， S., JOUBÉS， J., LESSIRE， R., DOMERGUE, F. (2011.) Production of wax esters from acyl-CoAs by FAR-WS fusion proteins. 5th European Symposium on Plant Lipids, Book of Abstracts, p. 91. DOI: 10.1194/jlr.M029512

37. DUAN, H., SCHULER, M. A. (2005.) Differential expression and evolution of the Arabidopsis CYP86A subfamily. Plant Physiology 137. 1067-1081. DOI: 10.1104/pp. 104.055715

38. FALLIK, E., GRINBERG, S., ALKALAI, S., YEKUTIELI, O., WISEBLUM, A., REGEV, R., BERES, H., BAR-LEV, E. (1999.) A unique rapid hot water treatment to improve storage quality of sweet pepper. Postharvest Biology and Technology 15. 2532. DOI: 10.1016/S0925-5214(98)00066-0

39. FARD, K. G., KAMARI, S., GHASEMNEZHAD, M., GHAZVINI, R. F. (2010.) Effect of chitosan coating on weight loss and postharvest quality of green pepper (Capsicum annuum L.) fruits. Proceedings of the 6th International Postharvest Symposium, Acta Horticulturae 877. 821-826.

40. FERnÁNDEZ, S., OSORIO, S., HEREDIA, A. (1999.) Monitoring and visualising plant cuticles by confocal laser scanning microscopy. Plant Physiology and Biochemistry 37. (10.) 789-794. DOI: 10.1016/S0981-9428(00)86692-9

41. GASIC, K., HERNANDEZ, A., KORBAN, S. S. (2004.) RNA extraction from different apple tissues rich in polyphenols and polysaccharides for cDNA library construction. Plant Molecular Biology Reporter 22. 437a-437g. DOI: 10.1007/BF02772687

42. GEISSER, S., GREEENHOUSE, S. W. 1958. An extension of Box's results on the use of the distribution in multivariate analysis. Annals of Mathematical Statistics 29. 885-891.

43. GHAFIR, S. A. M., GADALLA, S. O., MURAJEI, B. N., EL-NADY, M. F. (2009.) Physiological and anatomical comparison between four different apple cultivars under cold-storage conditions. Acta Biologica Szegediensis 53. (1.) 21-26.

44. GUTIERREZ, L., MAURIAT, M., GUÉNIN, S., PELLOUX, J., LEFEBVRE, J. F., LOUVET, R., RUSTERUCCI, C., MORITZ, T., GUERINEAU, F., BELLINI, C., 
VAN WUYTSWINKEL, O. (2008.) The lack of systematic validation of reference genes: a serious pitfall undervalued in reverse transcription polymerase chain reaction (RT-PCR) analysis in plants. Plant Biotechnology Journal 6. 609-618. DOI: 10.1111/j.1467-7652.2008.00346.x

45. HAMMER, P. F., EVENSEN, K. B. (1994.) Differences between rose cultivars in susceptibility to infection by Botrytis cinerea. Phytopathology 84. 1305-1312. DOI: 10.1094/Phyto-84-1305

46. HASLAM, T. M., MAÑAS-FERNÁNDEZ, A., ZHAO, L., KUNST, L. (2012.) Arabidopsis ECERIFERUM2 is a component of the fatty acid elongation machinery required for fatty acid extension to exceptional lengths. Plant Phsiology 160. (3.) 1164-1174. DOI: 10.1104/pp.112.201640

47. HOOKER, T.S., LAM, P., ZHENG, H., KUNST, L. (2007.) A core subunit of the RNA-processing/degrading exosome specifically influences cuticular wax biosynthesis in Arabidopsis. The Plant Cell 19. 904-913. DOI: 10.1105/tpc.106.049304

48. HU, C. G., HONDA, C., KITA, M., ZHANG, Z., TSUDA, T., MORIGUCHI, T. (2002.) A simple protocol for RNA isolation from fruit trees containing high levels of polysaccharides and polyphenol compounds. Plant Molecular Biology Reporter 20. 69a-69g. DOI: 10.1007/BF02801935

49. JAIN, M., NIJHAWAN, A., TYAGI, A. K., KHURANA, J. P. (2006.) Validation of housekeeping genes as internal controls for studying gene expression in rice by quantitaive real-time PCR. Biochemical and Biophysical Research Communications 345. 646-651. DOI: 10.1016/j.bbrc.2006.04.140

50. JANSSEN, B. J., THODEY, K., SCHAFFER, R. J., ALBA, R., BALAKRISHNAN, L., BISHOP, R., BOWEN, J. H., CROWHURST, R. N., GLEAVE, A. P., LEDGER, S., MCARTNEY, S., PICHLER, F. B., SNOWDEN, K. C., WARD, S. (2008.) Global gene expression analysis of apple fruit development from the floral bud to ripe fruit. BMC Plant Biololgy Feb 17. 8-16. DOI: 10.1186/1471-2229-8-16

51. JAYAKUMAR, R., MENON, D., MANZOOR, K., NAIR, S. V., TAMURA, H. (2010.) Biomedical applications of chitin and chitosan based nanomaterials. Carbohydrate Polymers 82. (2.) 27-232. DOI: 10.1016/j.carbpol.2010.04.074

52. JENKS, M. A., TUTTLE, H. A., EIGENBRODE, S. D., FELDMANN, K. A. (1995.) Leaf epicuticular waxes of the Eceriferum mutants in Arabidopsis. Plant Physiol. 108. 369-377. DOI: 10.1104/pp.108.1.369 
53. JENKS, M. A., ASHWORTH, E. N. (1999.) Plant epicuticular waxes: function, production and genetics. Horticultural Reviews 23. ISBN 0-471-25445-2 DOI: 10.1002/9780470650752.ch1

54. JETTER, R., KUNST, L. (2008.) Plant surface lipid biosynthetic pathways and their utility for metabolic engineering of waxes and hydrocarbon biofuels. The Plant Journal 54. 670-683. DOI: 10.1111/j.1365-313X.2008.03467.x.

55. JOUBÉS, J., PASCAL, S., BERNARD, A., SOREL, M., HASLAM, R. P., NAPIER, J. A., DOMERGUE, F., LESSIRE, R. (2011.) The Arabidopsis cer26 mutant is specifically afected in VLCFA elongation process. 5th European Symposium on Plant Lipids, Book of Abstracts, p. 78.

56. JOUBÉS, J., RAFFAELE, S., BOURDENX, B., GARCIA, C., LAROCHETRAINEAU, J., MOREAU, P., DOMERGUE, F., LESSIRE, R. (2008.) The VLCFA elongase gene family in Arabidopsis thaliana: phylogenetic analysis, 3D modeling and expression profiling. Plant Mol Biol 67. 547-566. DOI: 10.1007/s11103-008-9339-z

57. KANNANGARA, R., BRANIGAN, C., LIU, Y., PENFIELD, T., RAO, V., MOUILlE, G., HÖFTE, H., PAULY, M., RIECHMAN, J. L., BROUN, P. (2007.) The transcription factor WIN1/SHN1 regulates cutin biosynthesis in Arabidopsis thaliana. The Plant Cell 19. 1278-1294. DOI: 10.1105/tpc.106.047076

58. KOSMA, D. K., BOURDENX, B., BERnARD, A., PARSONS, E. P., LÜ, S., JOUBÉS, J., JENKS, M. A. (2009.) The impact of water deficiency on leaf cuticle lipids of Arabidopsis. Plant Physiology 151. 1918-1929. DOI: 10.1104/pp.109.141911

59. KÖLLER, W., PARKER, D. M., BECKER, C. M. (1991.) Role of cutinase in the penetration of apple leaves by Venturia inaequalis. Phythopathology 81. 1375-1379.

60. KROLIKOWSKI, K.A ., VICTOR, J.L., WAGLER, T.N., LOLLE, S.J., PRUITT, R.E. (2003.) Isolation and characterization of the Arabidopsis organ fusion gene HOTHEAD. The Plant Journal 35. 501-511. DOI: 10.1046/j.1365-313X.2003.01824.X

61. KUNST, L., CLEMENS, S., HOOKER, T. (2000.) Expression of the wax-specific condensing enzyme CUT1 in Arabidopsis. Biochemical Society Transactions 28. (6.) 651-654. DOI: 10.1042/0300-5127:0280651

62. KUNST, L., SAMUELS, A.L. (2003.) Biosynthesis and secretion of plant cuticular wax. Progress in Lipid Research 42. 51-80.

63. KUNST, L., SAMUELS, L. (2009.) Plant cuticles shine: advances in wax biosynthesis and export. Current opinion in Plant Biology 12. 721-727. DOI: 10.1016/j.pbi.2009.09.009 
64. LAI, C., KUNST, L., JETTER, R. (2007.) Composition of alkyl esters int he cuticular wax on inflorescence stems of Arabidopsis thaliana cer mutants. The Plant Journal 50. 189-196. DOI: 10.1111/j.1365-313X.2007.03054.x

65. LAZNIEWSKA, J., MACIOSZEK, V. K., KONONOWICZ, A. K. (2012.) Plantfungus interface: The role of surface structures in plant resistance and susceptibility to pathogenic fungi. Physiological and Molecular Plant Pathology 78. 24-30. DOI: 10.1016/j.pmpp.2012.01.004

66. LEE, S. B., JUNG, S. J., GO, Y. S., KIM, H. U., KIM, J. K., CHO, H. J., PARK, O. K., SUH, M. C. (2009.) Two Arabidopsis 3-ketoacyl CoA synthase genes, KCS20 and KCS2/DAISY, are functionally redundant in cuticular wax and root suberin biosynthesis, but differentially controlled by osmotic stress. The Plant Journal 60. 462475. DOI: 10.1111/j.1365-313X.2009.03973.x.

67. LEE, Y. P., YU, G. H., SEO, Y. S., HAN, S. E., CHOI, Y. O., KIM, D., MOK, I. G., KIM, W. T., SUNG, S. K. (2007.) Microarray analysis of apple gene expression engaged in early fruit development. DOI: 10.1007/s00299-007-0308-9 Plant Cell Reports 26. 917-926. LEONARD, A. E., PEREIRA, S. L., SPRECHER, H., HUANG, Y. S. (2004.) Elongation of long-chain fatty acids. Progress in Lipid Research 43. 3654.

68. LI, Y., BEISSON, F., KOO, A. J. K., MOLINA, I., POLLARD, M., OHLROGGE, J. (2007.) Identification of acyltransferases required for cutin biosynthesis and production of cutin with suberin-like monomers. PNAS 104. (46). 18339-18344. DOI: 10.1073/pnas.0706984104

69. LI, F., WU, X., LAM, P., BIRD, D., ZHENG, H., SAMUELS, L., JETTER, R., KUNST, L. (2008.) Identification of the wax ester synthase/acyl-coenzyme A:diacylglycerol acyltransferase WSD1 required for stem wax ester biosynthesis in Arabidopsis. Plant Physiology 148. 97-107. DOI: 10.1104/pp.108.123471

70. LYTOVCHENKO, A., BELEGGIA, R., SCHAUER, N., ISAACSON, T., LEUENDORF, J. E., HELLMANN, H., ROSE, J. K., FERNIE, A.R. (2009.) Application of GC-MS for the detection of lipophilic compounds in diverse plant tissues. Plant Methods 5. (4.) DOI: 10.1186/1746-4811-5-4.

71. LOWNDS, N. K., BANARAS, M., BOSLAND, P. W. (1993.) Relationships between postharvest water loss and physical properties of pepper fruit (Capsicum annuum L.). HortScience 28. (12.) 1182-1184. 
72. LURIE, S., FALLIK, E., KLEIN, J. D. (1996.) The effect of heat treatment on apple epicuticular wax and calcium uptake. Postharvest Biology and Technology 8. 271-277. DOI: 0.1016/0925-5214(96)00007-5

73. LÜ, S., SONG, T., KOSMA, D. K., PARSONS, E. P., ROWLAND, O., JENKS, M. A. (2009.) Arabidopsis CER8 encodes LONG-CHAIN ACYL-COA SYNTHETASE (LACS1) that has overlapping funkctions with LACS2 in plant wax and cutin synthesis. The Plant Journal 59. 553-564. DOI: 10.1111/j.1365-313X.2009.03892.x.

74. LÜ, S., ZHAO, H., PARSONS, E. P., XU, C., KOSMA, D. K., XU, X., CHAO, D., LOHREY, G., BANGARUSAMY, D. K., WANG, G., BRESSAN, R. A., JENKS, M. A. (2011.) The glossyhead1 allele of ACC1 reveals a principal role for moltidomain acetyl-coenzyme A carboxylase in the biosynthesis of cuticular waxes by Arabidopsis. Plant Physiology 157. 1079-1092. DOI: 10.1104/pp.111.185132

75. MAALEKUU, K., ELKIND, Y., LEIKIN-FRENKEL, A., LURIE, S., FALLIK, E. (2006.) The relationship between water loss, lipid content, membrane integrity and LOX activity in ripe pepper fruit after storage. Postharvest Biology and Technology 42. 248-255. DOI: 10.1016/j.postharvbio.2006.06.012

76. MAGUIRE, K. M., BANKS, N. H., OPARA, L. U. (2001.) Factors affecting weight loss of apples. Horticultural Reviews 25. ISBN 0-471-34933-X

77. MENGEL, K., KIRKBY, E. A. (2001.) Principles of plant nutrition (5th edition). Kluwer Academic Publishers, Dordrecht, The Netherlands. ISBN 0-7923-7150-X

78. METZ, J. G., POLLARD, M. R., ANDERSON, L., HAYES, T. R., LASSNER, M. W. (2000.) Purification of a jojoba embryo fatty acyl-coenzyme A reductase and expression of its cDNA in high erucic acid rapeseed. Plant Phyiology 122. 635-644. DOI: $10.1104 / \mathrm{pp} \cdot 122.3 .635$

79. Millar, A. A., ClEmenS, S., ZACHGO, S., GIBLIN, M., TAYLOR, D. C., KUNST, L. (1999.) CUT1, an Arabidopsis gene required for cuticular wax biosynthesis and pollen fertility, encodes a very-long-chain fatty acid condensing enzyme. The Plant Cell 11. 825-838.

80. MINTZ-ORON, S., MANDEL, T., ROGACHEV, I., FELDBERG, L., LOTAN, O., YATIV, M., WANG, Z., JETER, R., VENGER, I., ADATO, A., AHARONI, A. (2008.) Gene expression and metabolism in tomato fruit surface tissues. Plant Physiology 147. 823-851. DOI: 10.1104/pp.108.116004 
81. NAGY, V., ALBERT, ZS., GYEPES, A., LELIK, L., KUZNYÁK, L., DEÁK, CS., MISKÓ, A., ERŐS-HONTI, ZS., HÖHN, M., TERBE, I., PAPP, I. (2011.) Investigation of epidermal and cuticular structures in relation to postharvest water-loss of bell pepper fruits. $5^{\text {th }}$ European Symposium on Plant Lipids, Book of Abstracts, p. 99., Gdansk.

82. NAWRATH, C. (2002.) The biopolymers cutin and suberin. The Arabidopsis Book DOI: $10.1199 /$ tab.0021

83. NICOT, N., HAUSMAN, J. F., HOFFMANN, L., EVERS, D. (2005.) Housekeeping gene selection for real-time RT-PCR normalization in potato during biotic and abiotic stress. Journal of Experimental Botany 56. (421.) 2907-2914. DOI: 10.1093/jxb/eri285

84. ORGELL, W. H. (1954.) The isolation of plant cuticle with pectin enzymes. Plant Physiology 30. (1.) 78-80. DOI: 10.1104/pp.30.1.78

85. PARSONS, E. P., POPOPVSKY, S., LOHREY, G. T., LÜ, S., ALKALAI-TUVIA, S., PERZELAN, Y., PARAN, L., FALLIK, E., JENKS, M. A. (2012.) Fruit cuticle lipid composition and fruit post-harvest water loss in an advanced backcross generation of pepper (Capsicum sp.). Physiologia Plantarum 146. (1.) 15-25. DOI: 10.1104/pp.30.1. 78

86. PASCAL, S., BERNARD, A., SOREL, M., PERVENT, M., VILE, D., HASLAM, R. P., NAPIER, J.A., LESSIRE, R., DOMERGUE, F., JOUBÈS, J. (2013.) The Arabidopsis cer26 mutant, like the cer2 mutant, is specifically affected in the very long chain fatty acid elongation process. The Plant Journal 73. (5.) DOI: 10.1111/tpj.12060

87. PASQUARIEllo, M. S., REGA, P., MigliozZI, T., CAPUANO, L. R., SCORTICHINI, M., PETRICCIONE, M. (2013.) Effect of cold storage and shelf life on physiological and quality traitsof early ripening pear cultivars. Scientia Horticulturae 162., 341-350. DOI: 10.1016/j.scienta.2013.08.034

88. PODANI, J. (2007.) A szárazföldi növények evolúciója és rendszertana. ELTE Eötvös Kiadó, Budapest.

89. PODILA, G. K., ROGERS, L. M., KOLATTUKUDY, P. E. (1993.) Chemical signs from avocado surface wax trigger germination and appressorium formation in Colletotrichum gloeosporoides. Plant Physiology 103. 267-272. DOI: 10.1104/pp.103. 1.267 
90. POLLARD, M., BEISSON, F., LI, Y., OHLROGGE, J.B. (2008.) Building lipid barriers: biosynthesis of cutin and suberin. Trends in Plant Science 13. (5.) 236-246. DOI: 10.1016/j.tplants.2008.03.003.

91. PRUITT, R. E., VIELLE-CALZADA, J. P., PLOENSE, S. E., GROSSNIKLAUS, U., LOLLE, S. J. (2000.) FIDDLEHEAD, a gene required to suppress epidermal cell interactions in Arabidopsis, encodes a putative lipid biosynthetic enzyme. PNAS 97. (3.) 1311-1316. DOI: 10.1073/pnas.97.3.1311

92. RASHOTTE, A.M., JENKS, M.A., FELDMANN, K.A. (2001.) Cuticular waxes on eceriferum mutants of Arabidopsis thaliana. Phytochemistry 57. 115-123. DOI: 10.1016/s0031-9422(00)00513-6

93. RAWSTHORNE, S. (2002.) Carbon flux and faty acid synthesis in plants. Progress in Lipid Research 41. 182-196. DOI: 10.1016/S0163-7827(01)00023-6

94. REUVENI, M., TUZUN, S., COLE, J. S., SIEGEL, M. R., NESMITH, W. C., KUS, J. (1987.) Removal of duvatrienediols from the surface of tobacco leaves increases heir susceptibility to blue mold. Physiological and Molecular Plant Pathology 30. 441-451. DOI: 10.1016/0885-5765(87)90023-3

95. RIEDERER, M., MÜLLER, C. (ed., 2006.) Biology of the plant cuticle. Blackwell Publishing Ltd., Oxford. ISBN-10:1-4051-3268-X DOI: 10.1600/036364408785679914

96. ROWLAND, O., LEE, R., FRANKE, R., SCHREIBER, L., KUNST, L. (2007.) The CER3 wax biosythetic gene from Arabidopsis thaliana is allelic to WAX2/YRE/FLP1. FEBS Letters 581. 3538-3544. DOI: 10.1016/j.febslet.2007.06.065

97. ROWLAND, O., ZHENG, H., HEPWORTH, S.R., LAM, P., JETTER, R., KUNST, L. (2006.) CER4 encodes an alcohol-forming fatty acyl-coenzyme A reductase involved in cuticular wax production in Arabidopsis. Plant Physiology 142. 866-877. DOI: $10.1104 /$ pp.106.086785

98. SALADIÉ, M., MATAS, A. J., ISAACSON, T., JENKS, M. A., GOODWIN, S. M., NIKLAS, K. J., XIAOLIN, R., LABAVITCH, J. M., SHACKEL, K. A., FERNIE, A. R., LYTOVCHENKO, A., O’NEILL, M. A., WATKINS, C. B., ROSE, J. K. C. (2007.) A reevaluation of the key factors that influence tomato fruit softening and integrity. Plant Physiology 144. 1012-1028. DOI: 10.1104/pp.107.097477 
99. SALAS, J. J., OHLROGGE, J. B. (2002.) Characterization of substrate specifity of plant FatA and FatB acyl-ACP thioesterases. Archives of Biochemistry and Biophysics 403. 25-34. DOI: 10.1016/S0003-9861(02)00017-6

100. SAMUELS, L., KUNST, L., JETTER, R. (2008.), Sealing plant surfaces: cuticular wax formation by epidermal cells. Annu. Rev. Plant Biol. 59. 683-707. DOI: 10.1146/annurev.arplant.59.103006.093219.

101. SCHREIBER, L. (2010.) Transport barriers made of cutin, suberin and associated waxes. Trend sin Plant Science 15. (10.) 546-553. DOI: 10.1016/j.tplants.2010.06.004

102. SEO, P. J., PARK, C. M. (2011) Cuticular wax biosynthesis as a way of inducing drought resistance. Plant Signaling \& Behavior 6. (7.) 1043-1045. DOI: 10.4161/psb.6.7.15606

103. SEO, P. J., LEE, S. B., SUH, M. C., PARK, M. J., GO, Y. S., PARK, C. M. (2011) The MYB96 transcription factor regulated cuticular wax biosynthesis under drought conditions in Arabidopsis. The Plant Cell 23. 1138-1152. DOI: 10.1105/tpc.111.083485

104. SHEPHERD, T., GRIFFITHS, D. W. (2006.) The effect of stress on plant cuticular waxes. New Phytologist 171. 469-499. DOI: 10.1111/j.14698137.2006.01826.X

105. SHOCKEY, J.M., FULDA, M.S., BROWSE, J.A. (2002.) Arabidopsis contains nine long-chain acyl-coenzyme A synthetase genes that participate in fatty acid and glycerolipid metabolism. Plant Physiology 129. 1-13. DOI: 10.1104/pp.003269

106. SMITH, D. L., STOMMEL, J. R., FUNG, R. W. M., WANG, C. Y., WHITAKER, B. D. (2006.) Influence of cultivar and harvest method on postharvest storage quality of pepper (Capsicum anuum L.) fruit. Postharvest Biology and Technology 42. 243-247. DOI: 10.1016/j.postharvbio.2006.06.013

107. SOGLIO, V., COSTA, F., MOLTHOFF, J. W., WEEMEN-HENDRIKS, W. M. J., SCHOUTEN, H. J., GIANFRANCESCHI, L. (2009.) Transcription analysis of apple fruit development using cDNA microarrays. Tree Genetics \& Genomes 5. 685698. DOI: 10.1007/s11295-009-0219-8

108. SUH, M. C., SAMUELS, L., JETTER, R., KUNST, L., POLLARD, M., OHLROGGE, J., BEISSON, F. (2005.) Cuticular lipid composition, surface structure, and gene expression in Arabidopsis stem epidermis. Plant Physiology 139. 1649-1665. DOI: 10.1104/pp.105.070805 
109. SZAKIEL, A., PACZKOWSKI, C., PENSEC, F., BERTSCH, C. (2012.) Fruit cuticular waxes as a source of biologcially active triterpenoids. Phytochemistry Reviews DOI: 10.1007/s11101-012-9241-9.

110. TANG, D., SIMONICH, M. T., INNES, R. W. (2007.) Mutations in LACS2, a long-chain acy-coenzyme A synthetase, enhance susceptibility to avirulent Pseudomonas syringae but confer resistance to Botrytis cinerea in Arabidopsis. Plant Physiology 144. 1093-1103. DOI: 10.1104/pp.106.094318

111. TERBE, I., SLEZÁK, K., KAPPEL, N. (2011.) Kertészeti és szántóföldi növények fejlődési rendellenességei. Mezőgazda Kiadó, Budapest ISBN 978-963-286623-9, p. 93-179.

112. TU, K., NICOLAÏ, B., DE BARDEMAEKER, J. (2000.) Effects of relative humidity on apple quality under simulated shelf temperature storage. Scientia Horticulturae 85. 217-229. DOI: 10.1016/S0304-4238(99)00148-X

113. VERARDO, G., PAGANI, E., GEATTI, P., MARTINUUZI, P. (2003.) A thorough study of the surface wax of apple fruits. Analitical and Bioanalitical Chemistry 376. 659-667. DOI: 10.1007/s00216-003-1945-7

114. VERAVERBEKE, E. A., VAN OOSTVELDT, P., DECASTRO, I. C., NICOLAI, B. M. (2001a.) Analysis of apple (Malus domestica Borkh.)wax by means of chromatographic and confocal microscopy. Proceedings of the 4th International Conference On Postharvest, Acta Horticulturae 553. 519-522. DOI:

115. VERAVERBEKE, E. A., LAMMERTYN, J., SAEVELS, S., NICOLAI, B. M. (2001b.) Changes in chemical wax composition of three different apple (Malus domestica Borkh.) cultivars during storage. Postharvest Biology and Technology 23. 197-208. DOI: 10.1016/S0925-5214(01)00128-4

116. VERAVERBEKE, E. A., VAN BRUAENE, N., VAN OOSTVELDT, P., NICOLAI, B. M. (2001c.) Non destructive analysis of the wax layer of apple (Malus domestica Borkh.) by means of confocal laser scanning microscopy. Planta 213. 525533.

117. WALLIS, J. G., WATTS, J. L., BROWSE, J. (2002.) Polyunsaturated fatty acid synthesis: what will they think of next? Trends in Biochemical Sciences 27. (9.) 467-473. DOI: 10.1016/S0968-0004(02)02168-0

118. WELLESEN, K., DURST, F., PINOT, F., BENVENISTE, I., NETTESHEIM, K., WISMAN, E., STEINER-LANGE, S., SAEDLER, H., YEPHREMOV, A. (2001.) Functional analysis of the LACERATA gene of Arabidopsis provides evidence for 
different roles of fatty acid $\omega$-hydroxylation in development. PNAS 98. (17.) 96949699. DOI: 10.1073/pnas.171285998

119. WEN, M., JETTER, R. (2009.) Composition of secondary alcohols, ketones, alkanediols, and ketols in Arabidopsis thaliana cuticular waxes. Journal of Eperimental Botany, 60. (6.) 1811-1821. DOI: 10.1093/jxb/erp061

120. WENG, H., MOLINA, I., SHOCKEY, J., BROWSE, J. (2010.) Organ fusion and defective cuticle function in a lacs1 lacs2 double mutant of Arabidopsis. Planta 231. 1089-1100. DOI: 10.1007/s00425-010-1110-4

121. WHITAKER, B. D., SCHMIDT, W. F., KIRK, M. C., BARNES, S. (2001.) Novel fatty acid esters of p-coumaryl alcohol in epicuticular wax of apple fruit. Journal of Agricultural Food Chemistry 49. 3787-3792. DOI: 10.1021/jf010409n

122. WIEDENHOEFT, A. C. (2006.) Plant nutrition. Chelsea House Publishers, New York, USA. ISBN 0-7910-8564-3

123. XIA, Y., NIKOLAU, B.J., SCHNABLE, P.S. (1997.) Developmental and hormonal regulation of the Arabidopsis CER2 gene that codes for a nuclear-localized protein required for the normal accumulation of cuticular waxes. Plant Physiol. 115. 925-937. DOI: 10.1104/pp.115.3.925

124. XIAO, F., GOODWIN, S. M., XIAO, Y., SUN, Z., BAKER, D., TANG, X., JENKS, M. A., ZHOU, J. M. (2004.) Arabidopsis CYP86A2 represses Pseudomonas syringae type III genes and is required for cuticle development. The EMBO Journal 23, 2903-2913. DOI: 10.1038/sj.emboj.7600290

125. YEPHREMOV, A., SCHREIBER, L. (2005.) The dark side of the cell wall: Molecular genetics of plant cuticle. Plant Biosystems, 139. (1.) 74-79. DOI: $10.1080 / 11263500500059835$

126. ZHENG, H., ROWLAND, O., KUNST, L. (2005.) Disruptions of the Arabidopsis enoyl-CoA reductase gene reveal an essential role for very-long chain fatty acid synthesis in cell expansion during plant morphogenesis. The Plant Cell 17. 1467-1481. DOI: 10.1105/tpc.104.030155

127. ZSOM, T. (2007.) Az étkezési paprika minőségváltozása a szedés utáni időszak alatt. Doktori értekezés. Budapesti Corvinus Egyetem. 


\section{AZ ÉRTEKEZÉS TÉMAKÖRÉBŐL MEGJELENT PUBLIKÁCIÓK JEGYZÉKE}

\section{Folyóiratcikkek:}

Albert Zs., Ivanics B., Molnár A., Miskó A., Tóth M., Papp I. (2012) Candidate genes of cuticle formation show characteristic expression in the fruit skin of apple. Plant Growth Regulation, DOI: 10.1007/s10725-012-9779-y

Albert Zs., Erős-Honti Zs., Solymossy G., Kuznyák L., Miskó A., Deák Cs., Ladányi M., Terbe I., Papp I. (2012) Epidermal and exodermal tissue structures are characteristic for the long shelf-life 'Kárpia' pepper cultivar. Acta Alimentaria 41. (Suppl.), pp. 1-11, DOI: 10.1556/AAlim.41.2012.Suppl.1

Albert Zs., Ivanics B., Molnár A., Deák Cs., Miskó A., Tóth M., Papp I. (2013.) Expression analysis of KCS genes potentially involved in cuticular wax production in the apple cultivar 'Gegesi Zöld'. Acta Horticulturae 981: II Balkan Symposium on Fruit Growing, 205-208.

Albert Zs., Ivanics B., Molnár A., Deák Cs., Miskó A., Tóth M., Papp I. (2011) Characterization of gene expression in apple, connected potentially to cuticular wax production. Acta Biologica Szegediensis 55(1): 59-61.

Albert Zs., Deák Cs., Miskó A., Tóth M., Papp I. (2011) Development of cDNA normalization system and preliminary transcription analysis of KCS genes in apple tissues. Acta Universitatis Agriculturae et Silviculturae Mendelianae Brunensis 59(3): 9-12.

\section{Konferencia kiadványok:}

Albert Zs., Molnár A., Ivanics B., Miskó A., Deák Cs., Tóth M., Papp I. (2011) Expression analysis of genes potentially involved in epicuticular wax production in apple. Second Balkan Symposium on Fruit Growing, Book of Abstracts, p. 29., Pitesti.

Albert Zs., Kuznyák L., Beh M., Deák Cs., Miskó A., Gyepes A., Tóth M., Papp I. (2011) Investigation of diversity of cuticular waxes on two apple cultivars. $5^{\text {th }}$ European Symposium on Plant Lipids, Book of Abstracts, p. 96., Gdansk.

Molnár A., Albert Zs., Ivanics B., Deák Cs., Miskó A., Tóth M., Papp I. (2011) Studies aiming at identification of cuticular wax-associated genes in apple fruit. $5^{\text {th }}$ European Symposium on Plant Lipids, Book of Abstracts, p. 97., Gdansk.

Nagy V., Albert Zs., Gyepes A., Lelik L., Kuznyák L., Deák Cs., Miskó A., Erős-Honti Zs., Höhn M., Terbe I., Papp I. (2011) Investigation of epidermal and cuticular structures in relation to postharvest water-loss of bell pepper fruits. $5^{\text {th }}$ European Symposium on Plant Lipids, Book of Abstracts, p. 99., Gdansk.

Albert Zs., Kuznyák L., Deák Cs., Miskó A., Erős-Honti Zs., Höhn M., Terbe I., Papp I. (2011) Kutikuláris viaszok és bőrszöveti struktúrák szerepe két paprikafajta termésén a posztharveszt vízvesztés szabályozásában. Erdei Ferenc VI. Tudományos Konferencia III. kötet, pp. 199-204. 2011. augusztus 25-26., Kecskemét. (ISBN 978-615-5192-01-2) 
Albert Zs., Ivanics B., Deák Cs., Miskó A., Tóth M., Papp I. (2011) Nyári és téli alma kutikulájának mikroszkópos és molekuláris vizsgálata. A Budapesti Corvinus Egyetem kutatási, fejlesztési és innovációs teljesítményének növelése öt interdiszciplináris kiválósági központ létrehozásával, III. kutatási alprojekt: Kihívások és megoldások a XXI. század élelmiszertudományában, Záró konferencia. 2012. január 18-19., Budapest.

Albert Zs., Deák Cs., Miskó A., Tóth M., Papp I. (2010) Előzetes adatok az alma viaszoltságában szerepet játszó gének expressziójáról. Magyar Biokémiai Egyesület Vándorgyülése, 2010. augusztus 25-28. Budapest, Biokémia XXXIV. évf. (3.) p. 31.

Albert Zs., Deák Cs., Miskó A., Tóth M., Papp I. (2010) Development of cDNA normalization system and preliminary transcription analysis of KCS genes in apple tissues. 2nd International Conference on Horticulture Post-Graduate Study, Cenference Proceedings p. 47-53., Lednice. 


\section{KÖSZÖNETNYILVÁNÍTÁS}

Köszönetemet szeretném kifejezni Dr. Lukács Noémi tanszékvezető asszonynak, hogy lehetőséget kaptam a Növényélettan és Növényi Biokémia Tanszék munkájába történő bekapcsolódásra, valamint azt, hogy az itt töltött éveim során támogatásával, javaslataival, szakmai észrevételeivel segítette munkámat.

Szeretném megköszönni témavezetőm, Dr. Papp István témavezetői munkáját, amely nélkül dolgozatom nem készülhetett volna el.

Szeretnék köszönetet mondani Dr. Tóth Magdolna tanszékvezető asszonynak és Dr. Terbe István egyetemi tanár úrnak, hogy bekapcsolódhattam a Gyümölcstermő Növények és a Zöldség- és Gombatermesztési Tanszékek alma- és paprikanövényeket érintő munkájába, és hogy szakmai felkészültségükkel és tapasztalatukkal segítettek a fajtaválasztástól a felmerülő tudományos kérdések megválaszolásáig.

Hálás vagyok és köszönettel tartozom Dr. Ladányi Mártának, amiért idejét és erejét nem kímélve segítségemre volt az eredményeim statisztikai kiértékelésében, tanulmányaimhoz nélkülözhetetlen tanácsokat adott, tapasztalatával, tudományos szemléletével és emberségével segítette munkámat.

Köszönetet szeretnék mondani kollégáimnak a Növényélettan és Növényi Biokémia Tanszéken, hogy szakmai felkészültségükkel, figyelmükkel és támogatásukkal segítették munkámat. Dr. Szegő Anitának, amiért az alkalmazott modern tudományos módszerekhez szükséges kérdések feltevésében, az eredmények kiértékelésében gyakran kritikai és lényegre törő észrevételeivel segítségemre volt. Dr. Halász Krisztiánnak, amiért megkönnyítette az alkalmazott statisztikai és bioinformatikai eljárásokban történő elmélyülést. Dr. Pós Veronikának, a konfokális lézer pásztázó mikroszkóppal, valamint a qPCR készülékkel történő munkavégzésem során időt és energiát nem kímélve rendelkezésemre állt és segítette a munkámat. Deák Csillának, amiért segítségemre volt a viaszok kinyerésével kapcsolatos munkáim során, Demián Emesének, Németh Antalnénak, Bali Juditnak és Miskó Andrásnak amiért a kísérleteim során a felmerülő kiegészítő munkák során segítségemre voltak.

Köszönet illeti a kutatási munkámban részt vevő szakdolgozó hallgatóimat. Molnár Attilát, aki a génexpressziós vizsgálat alapozásában nyújtott segítséget. Kuznyák Lillát, a paprikák vízháztartását érintő vizsgálatban nyújtott segítségéért és végül, de nem utolsó 
sorban Ivanics Balázst, aki az alma fajtaösszehasonlítás és a kapcsolódó génexpressziós vizsgálat és qPCR eljárások során nyújtott nélkülözhetetlen segítséget.

Köszönöm Dr. Szikriszt Bernadett és Dr. Pfeiffer Péter génexpressziós vizsgálatokban és a real-time PCR eljárásban nyújtott segítségét, tanácsait, észrevételeit, valamint Solymossy Gábor segítségét a mikroszkópos munkák előkészítésében és kivitelezésében.

Szeretném megköszönni Gyepes Attila segítségét, aki a viaszok bepárlásában és a bepárolt viaszok mennyiségi analízisében segítségemre volt.

Köszönetemet szeretném kifejezni Király Ildikó egyetemi tanársegédnek, Kis Krisztiánné és Gyökös Imre Gergő tudományos segédmunkatársaknak, valamint Petróné Pázmándi Ildikó tanszéki mérnöknek, hogy a kísérleteimhez szükséges növények begyüjtésében segítségemre voltak.

Köszönöm Dr. Hegedűs Attila és Dr. Szalay László egyetemi docens uraknak, hogy elvállalták dolgozatom bírálatát a mühelyvitámra, és az elvárhatónál is alaposabb és részletesebb bírálatukkal segítették dolgozatom jobbá tételét. Köszönöm továbbá Dr. Höhn Mária tanszékvezető asszonynak, hogy segítségemre volt a dolgozatom botanikai kérdéseinek tisztázásában, valamint Dr. Bernáth Jenőnek, Dr. György Zsuzsannának és Dr. Gáspár Lászlónak, hogy mühelyvitám bizottsági tagjaiként kritikai észrevételeikkel hozzásegítettek dolgozatom véglegesítéséhez.

Köszönettel tartozom Dr. Laczay Péter ügyvezető úrnak, valamit Dr. Marsó Krisztinának amiért lehetőséget biztosítottak doktori munkám befejezésére munkahelyi teendőim mellett, és ebben messzemenően támogattak.

Szeretném továbbá megköszönni Konradek Norbertnek, családomnak és barátaimnak, hogy a doktori képzésem évei alatt tanácsaikkal, javaslataikkal, támogatásukkal és türelmükkel mellettem álltak és ezzel nélkülözhetetlen segítséget nyújtottak munkám elvégzéséhez, dolgozatom elkészítéséhez. 


\section{MELLÉKLETEK}

14.1. 1. Melléklet: A kutikuláris viaszok bioszintézisvel összefüggésbe hozható feltételezett alma-homológok PCR-termékeinek szekvenáltatott mintáinak nukleotid-szintü összevetése az eredeti szekvenciával

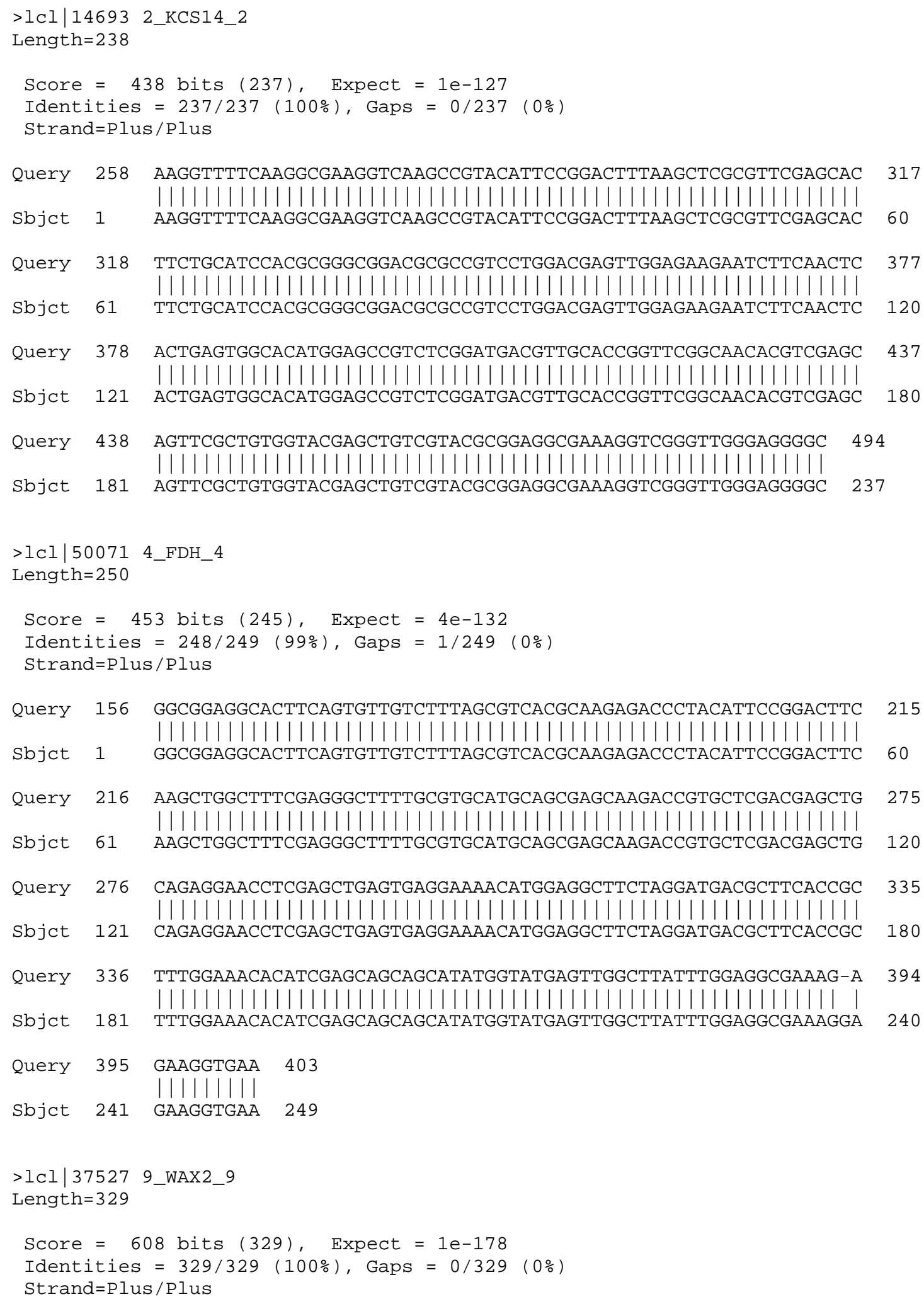




\begin{tabular}{|c|c|c|c|}
\hline Query & 180 & 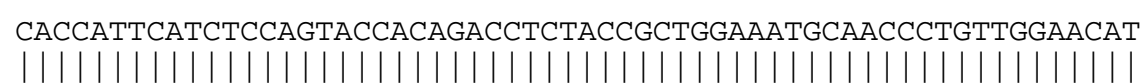 & 239 \\
\hline Sbjct & 1 & CACCATTCATCTCCAGTACCACAGACCTCTACCGCTGGAAATGCAACCCTGTTGGAACAT & 60 \\
\hline Query & 240 & 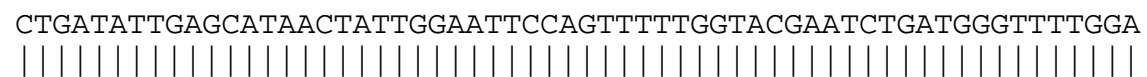 & 299 \\
\hline Sbjct & 61 & CTGATATTGAGCATAACTATTGGAATTCCAGTTTTTGGTACGAATCTGATGGGTTTTGGA & 120 \\
\hline Query & 300 & $\begin{array}{l}\text { TCAGTGTGCATGATCTATGGCTACGTTTTGGTTTTTGATTTTCTGAGATGTTTGGGGCAT } \\
|\|||||||||||||||||||||||||||||||||||||||||||||||||||||||||| \mid\end{array}$ & 35 \\
\hline Sbjet & 121 & TCAGTGTGCATGATCTATGGCTACGTTTTGGTTTTTGATTTTCTGAGATGTTTGGGGCAT & 180 \\
\hline Query & 360 & 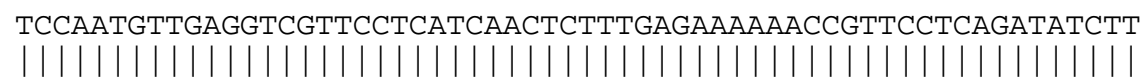 & 419 \\
\hline Sbjet & 181 & TCCAATGTTGAGGTCGTTCCTCATCAACTCTTTGAGAAAAAACCGTTCCTCAGATATCTT & 240 \\
\hline Query & 420 & 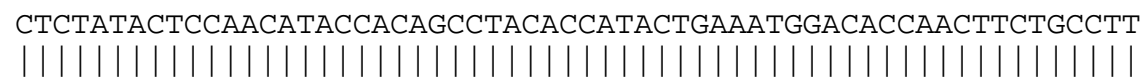 & 479 \\
\hline Sbjet & 241 & СTCTATACTCCAACATACCACAGCCTACACCATACTGAAATGGACACCAACTTCTGCCTT & 300 \\
\hline Query & 480 & $\begin{array}{l}\text { TTCATGCCTCTCTTTGATGCACTGGGGAA } 508 \\
\|\|\|\|\|\|\|\|\|\|\|\|\|\|\|\|\|\|\|\| \|\end{array}$ & \\
\hline \multicolumn{3}{|c|}{$\begin{array}{l}>\operatorname{lcl} \mid 25403 \quad 1 \\
\text { Length }=381\end{array}$} & \\
\hline \multicolumn{4}{|c|}{$\begin{array}{l}\text { Score }=7 \odot 4 \text { bits }(381), \text { Expect }=0 . \odot \\
\text { Identities }=381 / 381(10 \odot \%), \text { Gaps }=\odot / 381(\odot \%) \\
\text { Strand=Plus/Plus }\end{array}$} \\
\hline Query & 188 & 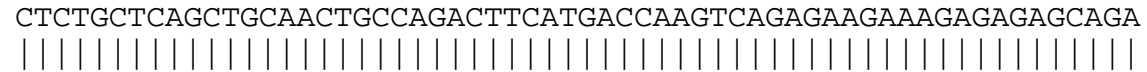 & 247 \\
\hline Sbjct & 1 & СTCTGCTCAGCTGCAACTGCCAGACTTCATGACCAAGTCAGAGAAGAAAGAGAGAGCAGA & 60 \\
\hline Query & 248 & $\begin{array}{l}\text { AGTTACAATTAGAGAGATGGGTTGCAGGACGCCATGAACACAAGGATTGGAGGTTGGG } \\
\end{array}$ & 36 \\
\hline Sbjct & 61 & AGTTACAATTAGAGAGATGGGTTTGCAGGACGCCATGAACACAAGGATTGGAGGTTGGGG & 12 \\
\hline Query & 308 & 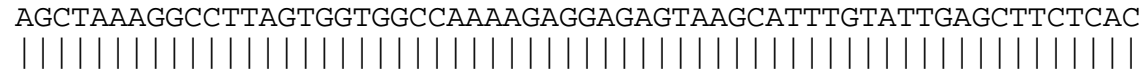 & 367 \\
\hline Sbjet & 121 & AGCTAAAGGCCTTAGTGGTGGCCAAAAGAGGAGAGTAAGCATTTGTATTGAGCTTCTCAC & 180 \\
\hline Query & 368 & $\begin{array}{l}\text { AAGCCTAAGCTTCTCTTCCTTGACGAACCGACAAGCGGCTTGACAGTGCAGCTTCTTA } \\
\end{array}$ & 427 \\
\hline Sbjet & 181 & AAGCCCTAAGCTTCTCTTCCTTGACGAACCGACAAGCGGCCTTGACAGTGCAGCTTCTTA & 24 \\
\hline Query & 428 & 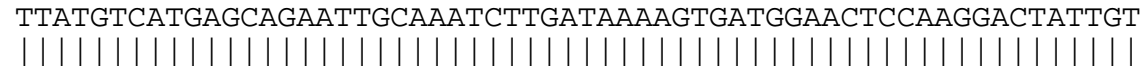 & 487 \\
\hline Sbjet & 241 & TTATGTCATGAGCAGAATTGCAAATCTTGATAAAAGTGATGGAACTCCAAGGACTATTGT & 300 \\
\hline Query & 488 & 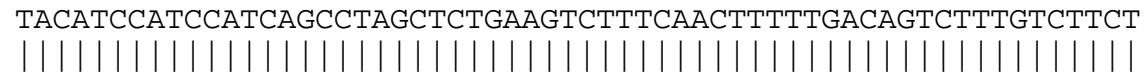 & 547 \\
\hline Sbjct & 301 & TACATCCATCCATCAGCCTAGCTCTGAAGTCTTTCAACTTTTTGACAGTCTTTGTCTTCT & 360 \\
\hline Query & 548 & $\begin{array}{l}\text { GTCTTCTGGAAGAACTGTCTA } 568 \\
\|\|\|\|\|\|\|\|\|\|\|\|\|\|\|\|\end{array}$ & \\
\hline Sbjct & 361 & GTCTTCTGGAAGAACTGTCTA & \\
\hline \multicolumn{4}{|c|}{$\begin{array}{l}\text { >lcl| } 59883 \text { 12_CER4_12 } \\
\text { Length=116 }\end{array}$} \\
\hline $\begin{array}{l}\text { Score } \\
\text { Ident } \\
\text { Stran }\end{array}$ & $\begin{array}{l}= \\
\text { ties } \\
\text { t=Plu }\end{array}$ & $\begin{array}{l}=7 \text { bits (112), Expect }=7 e-59 \\
=114 / 116(98 \%), \text { Gaps }=\odot / 116(\odot \%) \\
\text { S/Plus }\end{array}$ & \\
\hline
\end{tabular}




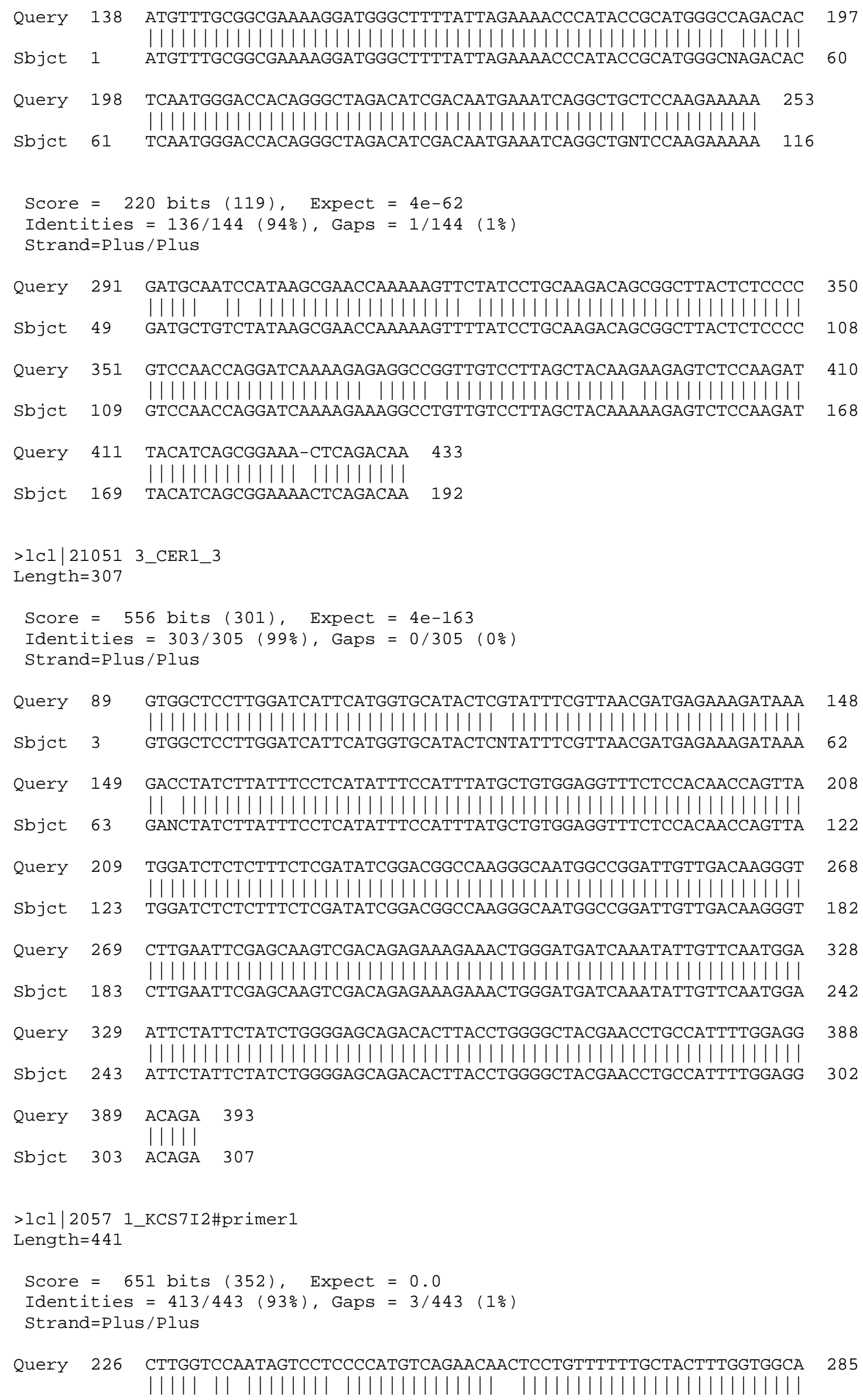




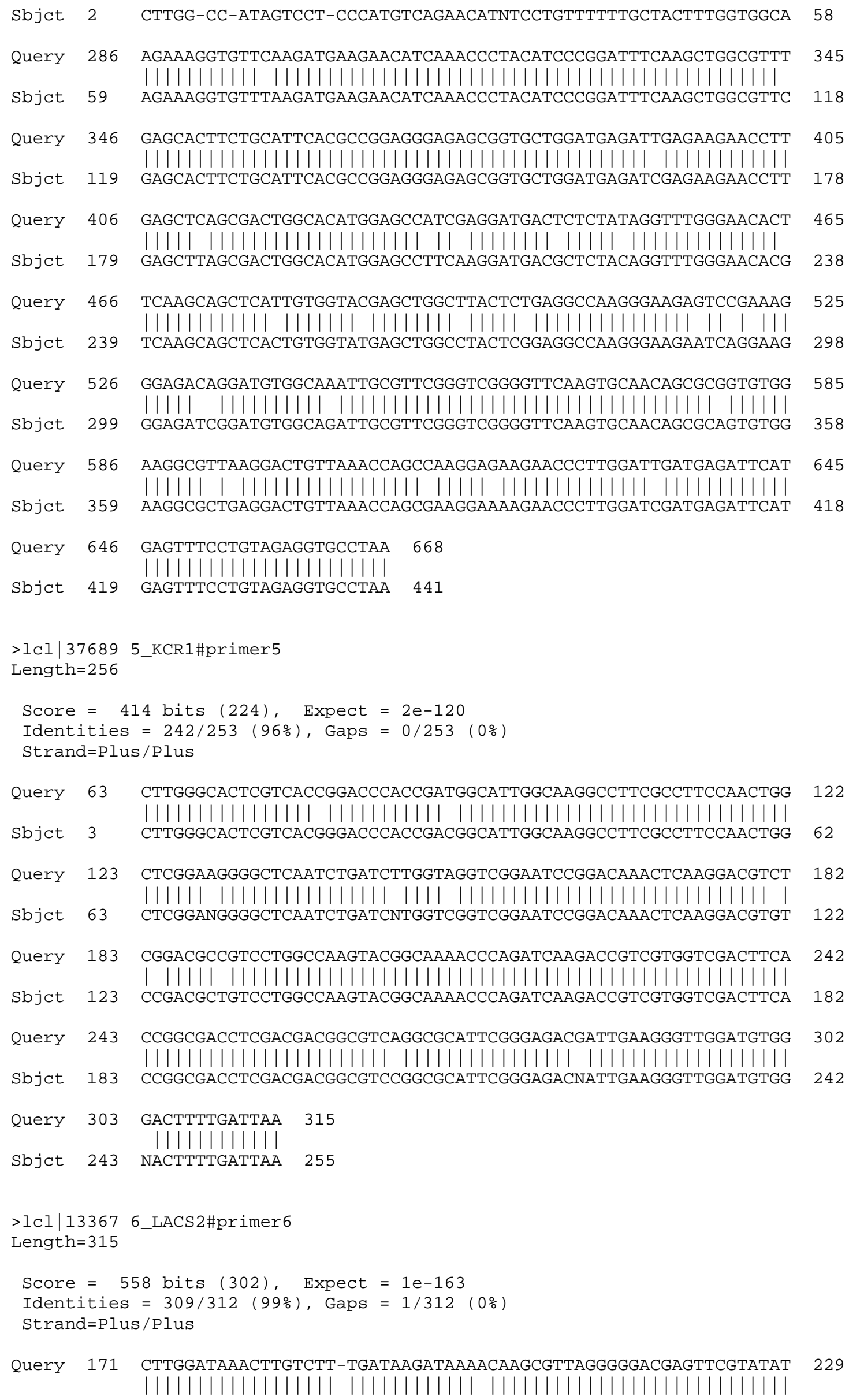




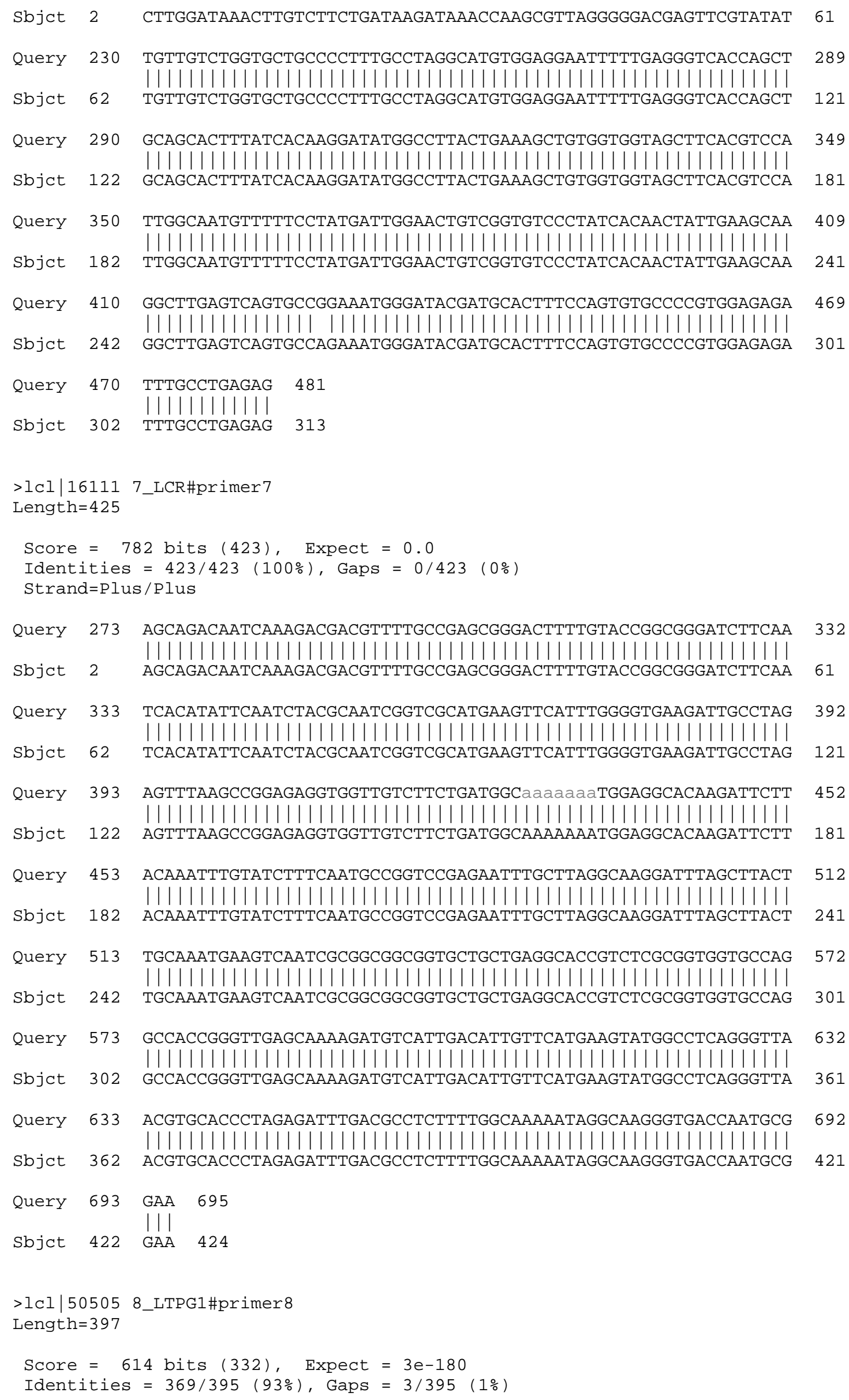




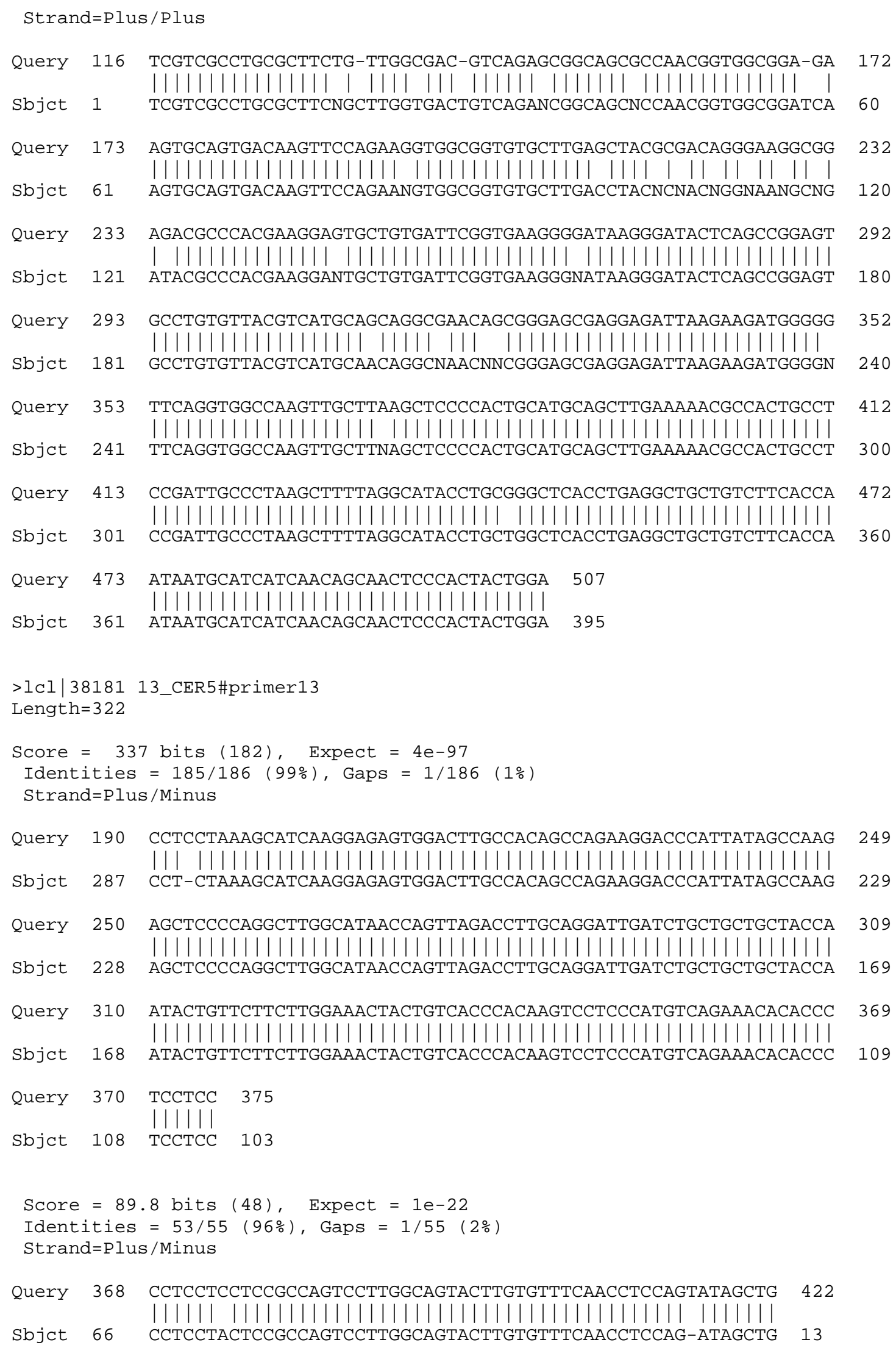




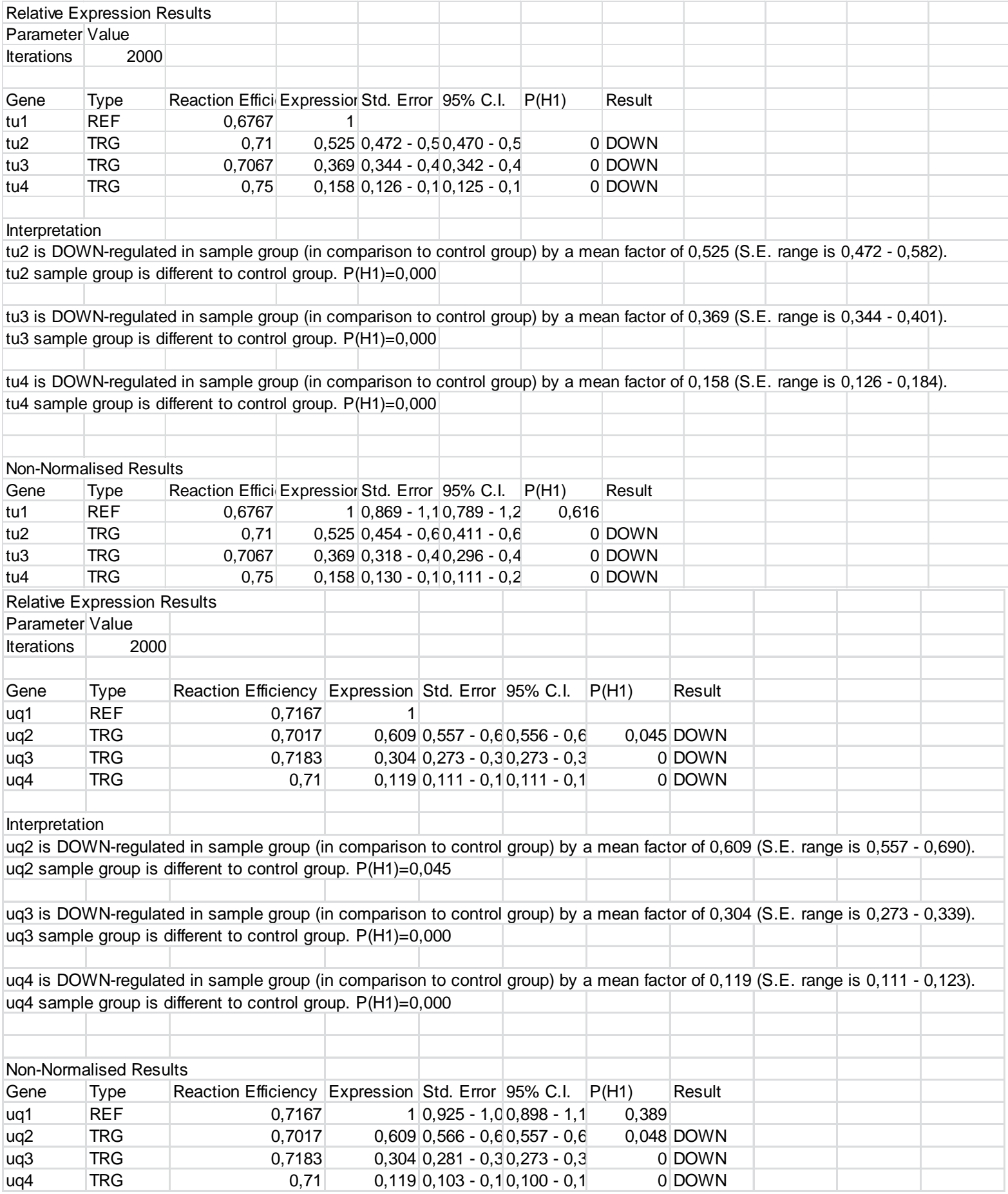

\subsection{Melléklet: A Lacerata homológ különböző szövetekben megjelenő relatív} expressziójának értékelése 


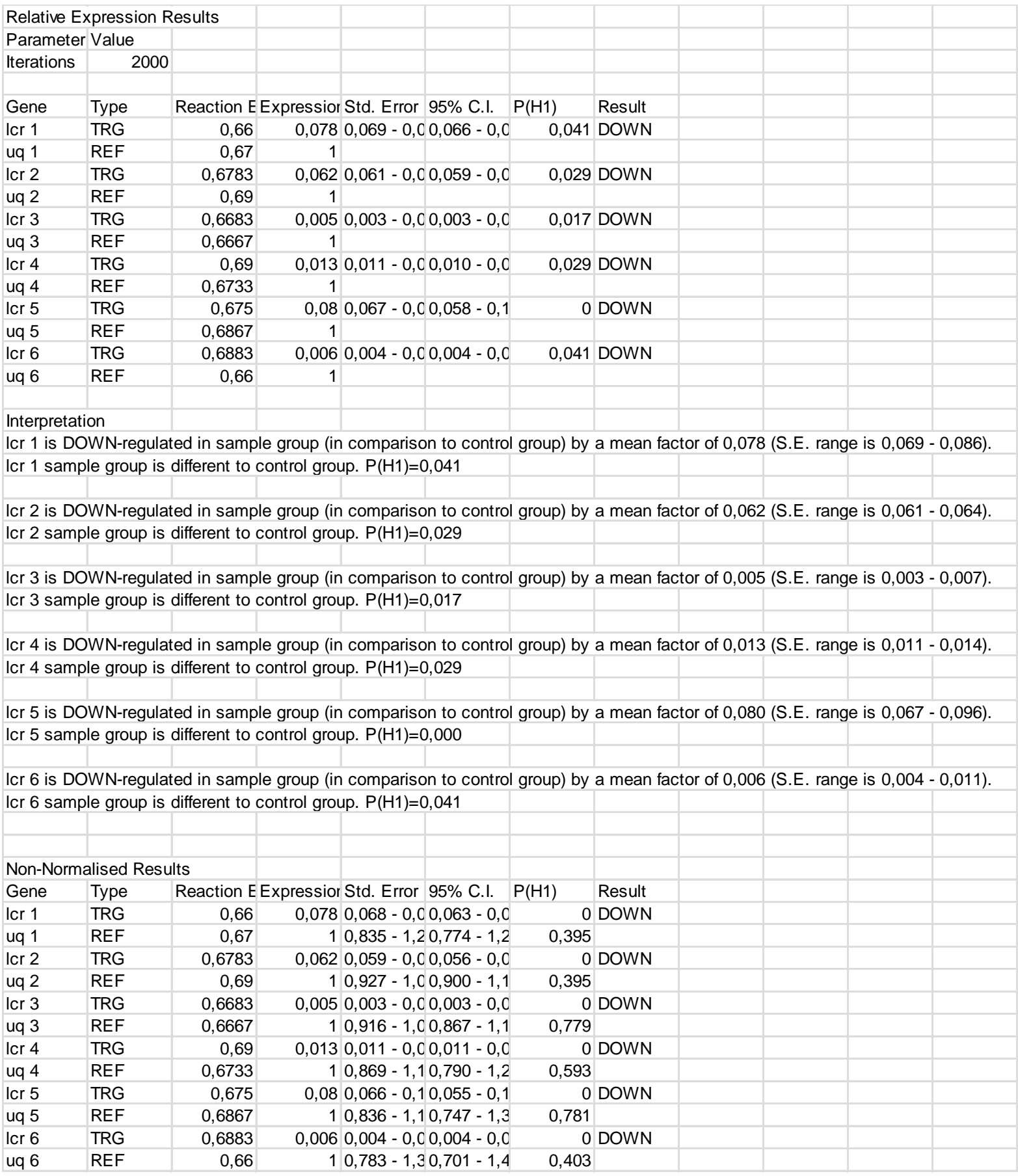

